\title{
LAND-BASED HIGH-RESOLUTION SEISMIC- REFLECTION SURVEYS OF SEVEN SITES IN DUVAL AND ST. JOHNS COUNTIES, NORTHEASTERN FLORIDA
}

\author{
By Jack K. Odum 1 \\ William J. Stephenson1 \\ Robert A. Williams 1 \\ David M. Worley' \\ David J. Toth2 \\ Rick M. Spechler ${ }^{3}$ \\ Thomas L. Pratt4
}

\section{Open-File Report 97-718}

Prepared for and in cooperation with St. Johns River Water Management District as part of U.S. Geological Survey/St. Johns River Water Management District Joint Funding Agreement

This report is preliminary and has not been reviewed for conformity with U.S. Geological Survey editorial standards and nomenclature. Any use of trade, product, or firm names is for descriptive purposes only and does not imply endorsement by the U.S. Government.

${ }^{1}$ U.S. Geological Survey

Denver, CO 80225

$2^{2}$ St. Johns River Water Management District

Palatka, FL 32178-1429
3U.S. Geological Survey

Altamonte Springs, FL 32718

${ }^{4}$ U.S. Geological Survey

Seattle, WA 98195 


\section{TABLE OF CONTENT}

Abstract............................................................................ 1

Introduction.................................................................. 1

Karst geomorphology ........................................................ 3

Hydrogeologic and stratigraphic framework ................................. 4

Surficial aquifer system................................................... 4

Intermediate confining ................................................... 4

Floridan aquifer system................................................... 4

High-resolution seismic reflection method...................................... 6

Previous Investigations.................................................. 6

USGS-SJRWMD 1997 seismic acquisition parameters..................... 8

Vertical and spatial resolution of seismic data............................ 8

Seismic data interpretation.................................................... 9

Site A: Fort George Island .......................................... 12

Site B: Oakridge Well field........................................... 16

Site C: Jacksonville Beach.................................................... 26

Site D: Brierwood Water Treatment Plant................................. $\quad 30$

Site E: Orangedale .................................................... 33

Site F: Bakersville......................................................... 35

Site G: Tocoi.......................................................... 38

Discussion and Conclusions.................................................... 40

Acknowledgments................................................................ 41

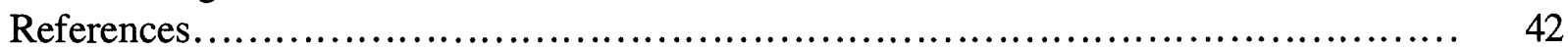

Appendix: Uninterpreted high-resolution seismic profiles......................... 45

\section{ILLUSTRATIONS}

Figure 1. Location map of high-resolution seismic reflection profiles obtained during this study: A-Fort George Island, B-Oakridge well field, CJacksonville Beach, D-Brierwood water treatment plant, E-Orangedale, F-Bakersville and G-Tocoi.

2. Generalized geology and hydrogeology of northeastern Florida................ 5

3. Simplified model of the Floridan aquifer system showing how a mechanism by which geologic discontinuities (fractures, faults, and solution pipes) can provide conduits for upward migration and mixing of higher chloride concentration water with freshwater (modified from Spechler, 1994, figure 37).

4. This figure shows an example of the stratigraphic correlation between the gamma-ray log from well D-665 and seismic reflection data imaged in northeastern Florida. 
5a. Location of high-resolution seismic reflection profiles on Fort George Island with respect to equal chloride concentration contours

5b. Interpretation of Fort George Island line 1 high-resolution seismic reflection profile, see figures 1 and 5 a for location....

5c. Interpretation of Fort George Island line 2 acquired from east to west perpendicular to Fort George Island line 1, see figures 1 and $5 \mathrm{a}$ for location.

6a. Map of the Oakridge well field (Site B) showing the relative locations of wells and six seismic reflection lines.

6b. Interpretation of Oakridge well field line 1 acquired from east to west along Alden Street, see figures 1 and 6a for location.

6c. Interpretation of Oakridge well field line 2 acquired with a 10 pound sledgehammer energy source and with a $2 \mathrm{~m}$ geophone spacing.

6d. Interpretation of Oakridge well field line 3 acquired perpendicular to Oakridge well field lines 2 and 4 , see figures 1 and $6 a$.

6e. Interpretation of Oakridge well field line 4, see figures 1 and 6 a for line location

6f. Interpretation of Oakridge well field line 5 acquired using a Wacker energy source, see figures 1 and 6 a for line location....

6g. Interpretation of Oakridge well field line 6 , see figures 1 and 6 a for location...

7a. Location of high-resolution seismic reflection lines at Jacksonville Beach (Site $\mathrm{C}$, figure 1)

7b. Interpretation of Jacksonville Beach line 1, see figures 1 and $7 \mathrm{a}$ for line location.

7c. Interpretation of Jacksonville Beach line 2, collected from west to east along $4^{\text {th }}$ Avenue $\mathrm{S}$., see figures 1 and $7 \mathrm{a}$ for line location.

8a. Location of high-resolution seismic reflection lines at Brierwood water treatment plant (Site D, figure 1)

8b. Interpretation of Brierwood line 1 acquired near Brierwood water treatment plant, see figures 1 and $8 \mathrm{a}$. 
8c. Interpretation of Brierwood line 2, see figures 1 and 8 a for line location

9a. Location map for the high-resolution seismic reflection line near Orangedale, Florida (Site E, figure 1)

9b. Interpretation of Orangedale line 1, see figures 1 and 9a for line location

10a. Location of high-resolution seismic reflection lines at Bakersville, Florida (Site F, figure 1)

10b. Interpretation of Bakersville line 1 acquired along state highway 208 , see figures 1 and 10a for line location.

10c. Interpretation of Bakersville line 2 showing near-surface downwarping and deformation of strata.

11a. Location of the high-resolution seismic reflection line near Tocoi, Florida (Site $\mathrm{G}$, figure 1)

11b. Interpretation of Tocoi line 1 seismic profile, see figures 1 and 11a for location

\section{TABLES}

Table 1. Generalized high-resolution seismic acquisition parameters for high-resolution seismic reflection profiles.

Table 2a. Generalized processing flow for all lines except Oakridge lines 2 and 3.......

Table 2b. Generalized processing flow for Oakridge lines 2 and 3. 


\title{
Land-Based High-Resolution Seismic Reflection Surveys of Seven Sites in Duval and St. Johns Counties, Northeastern Florida
}

\begin{abstract}
Water quality monitoring of the drinking-water supply wells tapping the upper Floridan aquifer have shown increases in chloride concentrations in some wells in Duval County and monitor wells in St. Johns County. Meanwhile, in other nearby production and monitor wells, the chloride concentrations are unchanged. It is speculated that geologic structures (fracture zones, solution pipes, cavities and paleosinkholes) in the underlying carbonate strata have breached the semi-confining units of the Floridan aquifer system thus allowing warmer and more saline water to flow upward and mix with fresher water aquifers. A reconnaissance investigation was conducted to determine if land-based high-resolution seismic reflection techniques could be used to identify the presence of karst terrain geologic structures at seven different sites located in various environmental settings (i.e. urban, residential and rural). Additionally, these surveys were performed to determine if land-based high-resolution seismic methods could be used as a tool to evaluate potential well field sites during the future water supply planning.

The results of this study are: (1) good-to-high quality data was collected, (2) depth of imaging varies with site conditions but rock strata are generally imaged within a depth interval of 30-400 m, (3) preliminary interpretations range from no identifiable karst features to clear evidence of buried solution cavities and collapse features, fracture zones, and possible nearsurface solution valleys.
\end{abstract}

\section{INTRODUCTION}

Observations of water quality data, specifically chloride concentration, have shown increases in some production wells at sites in Duval County and monitor wells in St. Johns County while at other nearby production and monitor wells the quality has remained unchanged (Toth, 1990; Spechler, 1994; Phelps and Spechler, 1997). Both groups of wells are pumping water from approximately the same depths within the Floridan aquifer system. It is postulated that the areal and vertical variability of temperature and chloride concentrations can be explained by the localized upward migration of warmer, poorer quality water from zones in or below the Lower Floridan aquifer. The conduits for this upward flow are believed to be along isolated geologic structures (fractures, faults, solution conduits, and/or paleosinkholes) that have breached the middle semi-confining unit of the Floridan aquifer system.

Marine seismic-reflection surveys have been conducted offshore, along major rivers (including St. Johns River) and in selected lakes in north central and central Florida. These river and lake surveys have gathered high quality data to depths generally ranging from 15 to 80 meters and imaged clear evidence of shallow karst collapse, subsidence and solution features. To determine if land-based surveys could achieve similar results, the U.S. Geological Survey (USGS) high-resolution seismic reflection group (Geologic Division, Central Region, Geologic Hazards Team), in cooperation with the St. Johns River Water Management District (SJRWMD), conducted the first land-based Mini-Sosie high-resolution seismic reflection method surveys in Duval and St. Johns Counties, northeastern Florida (figure 1). The Mini-Sosie method employed during this study has been successfully used by the USGS group to image faults and near-surface (25-800 $\mathrm{m}$ depth) deformation in neotectonic and earthquake investigations in other regions of 


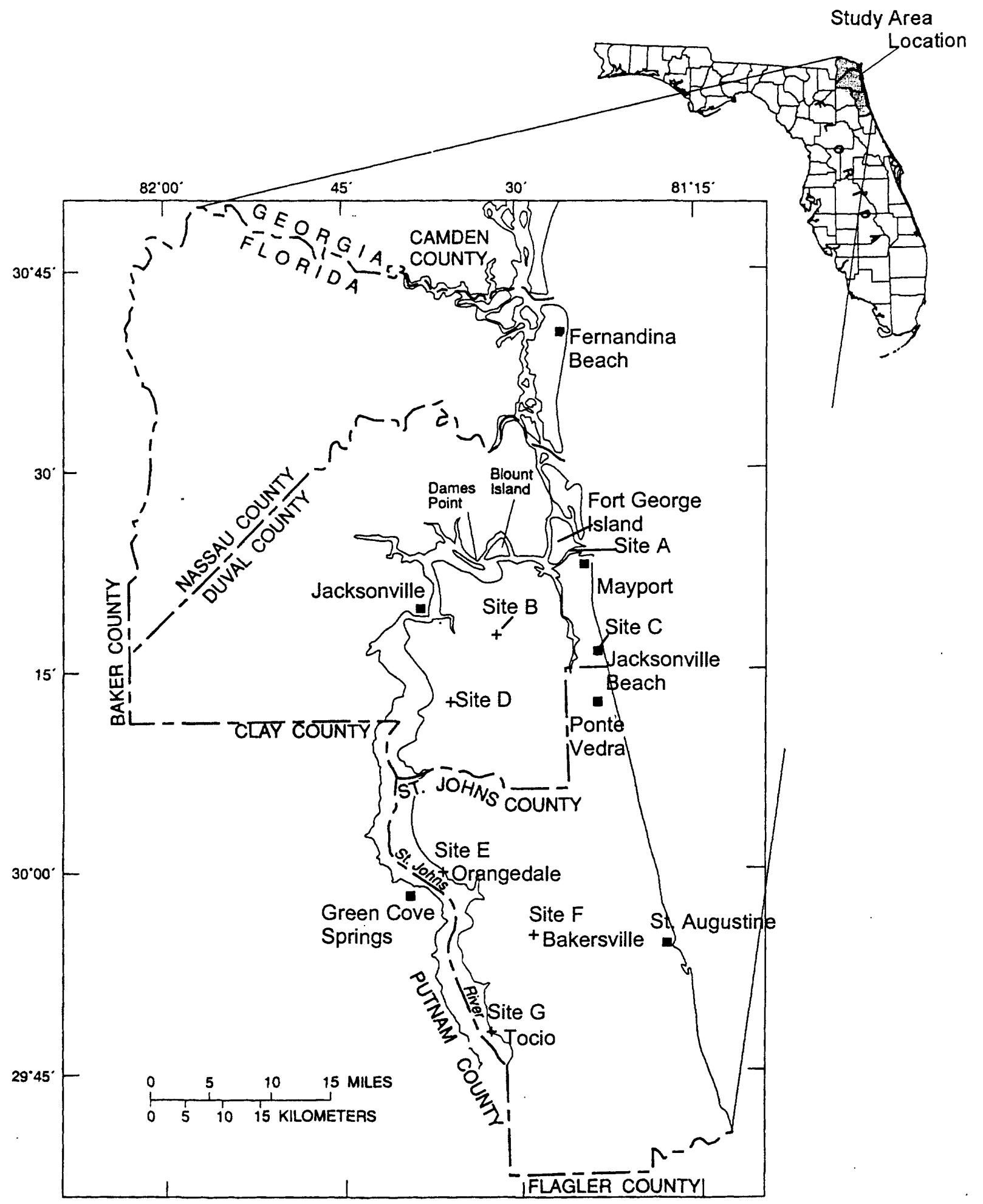

Figure 1. Location map of high-resolution seismic reflection profiles: obtained during this study: A- Fort George Island, B-Oakridge well field, C- Jacksonville Beach, D- Brierwood water treatment plant, E-Orangedale, F- Bakersville and G- Tocoi. 
the United States (Odum, et al., 1995; Stephenson et al., 1995; Pratt, et al., in press). The MiniSosie method was used here because it works well in the physically restrictive and culturally noisy urban environment and thus was thought to have potential since the majority of the sites to be investigated are located within urban or residential areas.

For this study, sites in Duval County were selected because monitoring showed increasing chloride concentrations and higher $\left(31^{\circ} \mathrm{C}\right)$ water temperature; whereas, sites in St. Johns County were selected because of higher $\left(27-30^{\circ} \mathrm{C}\right)$ water temperature. Primary goals of these reconnaissance land-based seismic reflection surveys were: (1) to image the geologic structures that may be providing pathways for the upward migration of poorer quality water near specific production and monitor wells and (2) to determine if the high-resolution seismic reflection method could be used as a tool to evaluate geologic conditions at purposed well sites in urban, residential and rural areas.

\section{KARST GEOMORPHOLOGY}

The stratigraphy of the Florida peninsula is predominantly composed of shallow-water carbonate rocks with a relatively thin veneer of interbedded carbonate/clastic and clastic, weaklyto-unconsolidated sedimentary units (Evans, et al., 1994). The shallow-water marine carbonate rocks formed in bank-margin environments and are predominantly limestone and dolomite. The mineral constituents of these carbonate rocks are relatively metastable and, therefore, susceptible to various degrees of dissolution as a result of the percolation of slightly acidic meteoric water. The aforementioned dissolution process results in the generation of surface and subterranean karst features.

In certain areas of Florida (central highlands), these characteristic karst features are visible at the surface in the form of dolines (sinkholes), often filled with water, and as springs and caverns. The surface expression of sinkholes can come in many forms. Individual dolines can range from less than $1 \mathrm{~m}$ to more than $100 \mathrm{~m}$ in depth and from $1 \mathrm{~m}$ to over $1 \mathrm{~km}$ in diameter. In map view, they may be irregular, elongate, circular, and have profiles that are conical, cylindrical, saucer-shaped, or irregular (White, 1988). In the subsurface, the dissolution process is also at work through a network of interconnected pores and geologic discontinuities (joints, fractures, and faults). As the weakly acidic (carbonic acid) waters are pulled downward by gravity, their flow continually widens their pathways by dissolving the surrounding limestone, with the result being the formation of large solution pipes, cavities, and caverns.

In general, the size, shapes, and profiles that were described for surface sinkholes and related features apply equally as well to those formed in the subsurface. If these features are small, are developed at depth and/or the overlying bridging strata is strong, there may be no surface expression to indicate the existence of these voids. These buried voids may remain open or be filled with large rubble blocks and/or with insoluble sand and clay material. Overlying strata may slowly deform plastically (sag) over the void, forming a depressed subsidence feature at the surface; and/or the overlying strata may fail suddenly as the roof material over the void collapses, creating a bowl-shaped, funnel-shaped, or cylindrical feature at the ground surface (Kindinger, et al., 1994). Within the study area, collapse structures that have reached the land surface are not found. Subsidence and collapse sinkholes may fill and be covered by sediments to the point that they are unrecognizable at the surface, thus becoming "buried" sinkholes.

The type, style, and time frame of development of dissolution features is, therefore, related to the thickness and lithologic make up of the stratigraphic section in which the dissolution feature forms as well as changing hydrologic conditions (i.e. water table) during their 
formation. Excellent discussions on the origin and nature of sinkholes and other karst-related features have been published by White (1988), Waltham (1989) and Beck and Sayed (1991).

\section{HYDROGEOLOGIC AND STRATIGRAPHIC FRAMEWORK}

The hydrologic flow in the study area is controlled at the surface and near-surface by the lithologic sequence of the local stratigraphic section. Northeast Florida is underlain by a thick sequence of marine sedimentary rocks that overlie a basement complex of metamorphic strata (Snyder et al., 1989). The primary water-bearing sediments are composed of limestone, dolomite, shell, clay and sand that range in age from late Paleocene to Holocene. Geologic units and corresponding hydrogeologic units are described in figure 2. Geologic units, in ascending order, are: Cedar Keys Formation of late Paleocene age, the Oldsmar Formation of early Eocene age, the Avon Park Formation of middle Eocene age, The Ocala Limestone of late Eocene age, the Hawthorn Formation of Miocene age, and the undifferentiated deposits of late Miocene to Holocene. Figure 2 also illustrates that two aquifer systems (the surficial and the Floridan) are present within in the study area.

\section{Surficial Aquifer System}

The surficial aquifer is the uppermost water-bearing unit in the study area. The aquifer consists of sand, clay, shell, dolomite, and limestone that ranges in age from middle Miocene to Holocene in age. In most of the area, the surficial aquifer system has two water-producing zones separated by beds of lower permeability. The aquifer, generally, is unconfined but may be semiconfined where beds of lower permeability are sufficiently thick and continuous. In some areas, the uppermost carbonate beds of the Hawthorn Formation are hydraulically connected with the overlying deposits, forming the lowermost part of the surficial aquifer system. The thickness of the surficial aquifer is variable, ranging from about 6 to $36 \mathrm{~m}$ (Spechler, 1994).

\section{Intermediate Confining Unit}

The intermediate confining unit (figure 2), which underlies the surficial aquifer system, primarily consists of the Hawthorn Formation of Miocene age. The unit consists of interbedded clay, silt, sand, limestone, and dolomite containing abundant amounts of phosphatic sand, granules, and pebbles. Throughout most of the area, the clays and silts in the intermediate confining unit serve as an effective confining layer that retards the vertical movement of water between the surficial aquifer system and the underlying Floridan aquifer system. The thickness of the intermediate confining unit ranges from about $15 \mathrm{~m}$ in southern St. Johns County to more than $150 \mathrm{~m}$ in the central part of Duval County (Spechler, 1994).

\section{Floridan Aquifer System}

The Floridan aquifer system consists of a highly permeable sequence of porous limestone dolomite which vary in age from late Paleocene to Eocene. The Floridan aquifer ranges in thickness from about $485 \mathrm{~m}$ to $670 \mathrm{~m}$ in the study area (Miller, 1986) and includes the Ocala Limestone, the Avon Park Formation, the Oldsmar Formation and the upper part of the Cedar Keys Formation.

The Floridan aquifer system is divided into the Upper Floridan aquifer and the Lower Floridan aquifer (figure 2) which are separated by a zone of lower permeability. Two major 


\begin{tabular}{|c|c|c|c|c|c|c|c|c|}
\hline 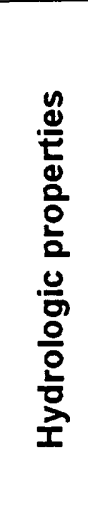 & 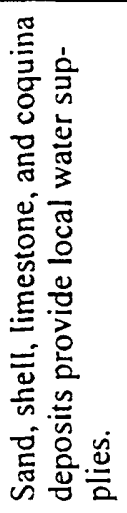 & 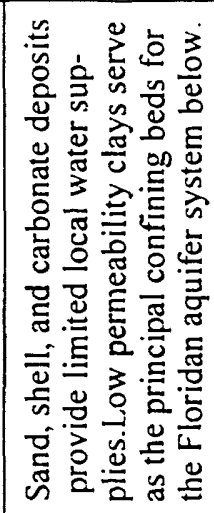 & 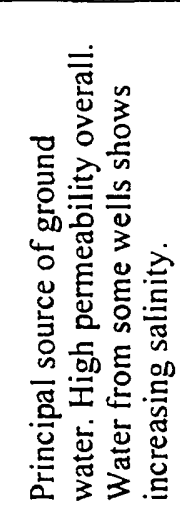 & 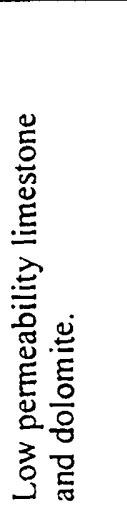 & 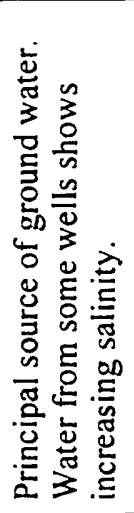 & 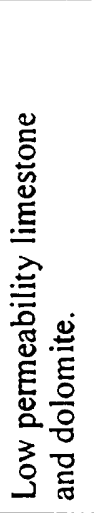 & 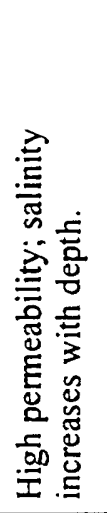 & 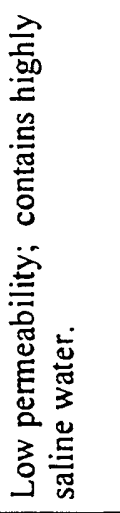 \\
\hline \multirow{3}{*}{ 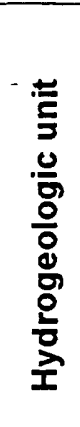 } & \multirow{3}{*}{ 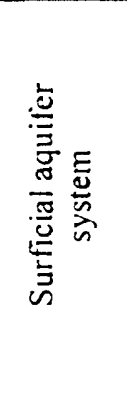 } & \multirow[t]{3}{*}{ 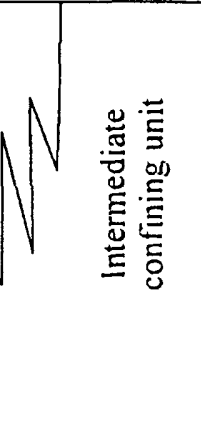 } & \multirow[t]{2}{*}{ 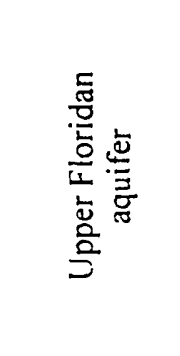 } & \multirow{2}{*}{ 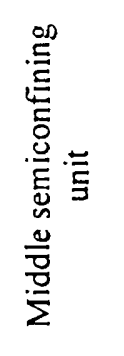 } & 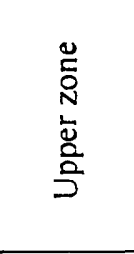 & 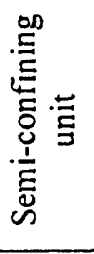 & 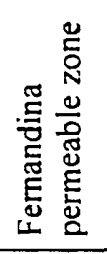 & \multirow[t]{3}{*}{ 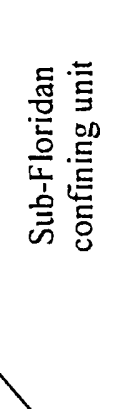 } \\
\hline & & & & & \multicolumn{3}{|c|}{$\begin{array}{c}\text { גəן!nbe } \\
\text { uRp!ı이 دәмо7 }\end{array}$} & \\
\hline & & & \multicolumn{5}{|c|}{ 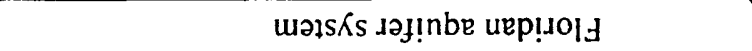 } & \\
\hline 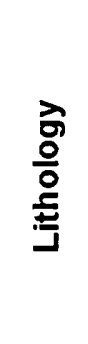 & 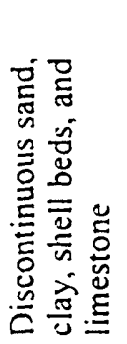 & 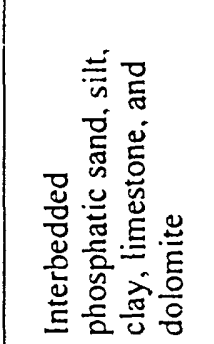 & 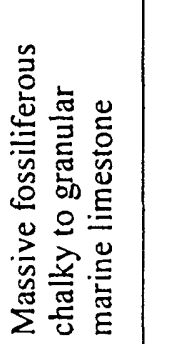 & \multicolumn{4}{|c|}{ 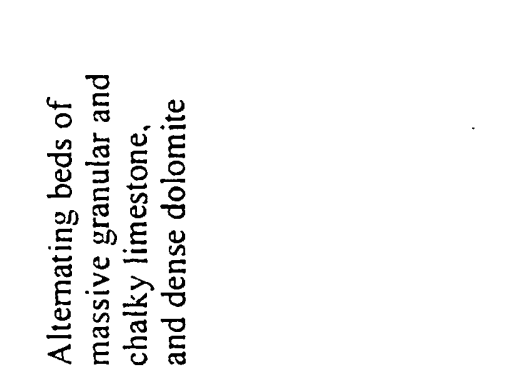 } & 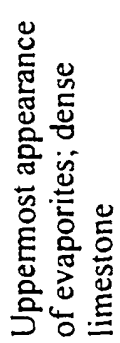 \\
\hline 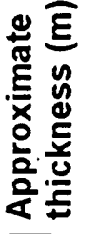 & 弚 & 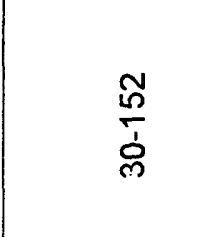 & 옴 & & & & & $\begin{array}{l}10 \\
10 \\
5 \\
0 \\
0 \\
0\end{array}$ \\
\hline \multirow{2}{*}{ 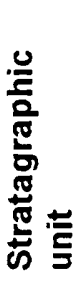 } & \multirow[t]{2}{*}{ 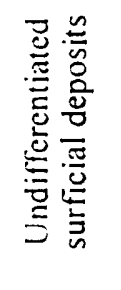 } & \multirow[t]{2}{*}{ 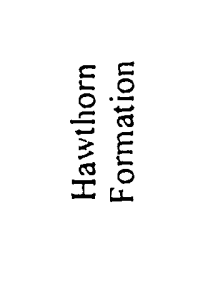 } & 苋 & \multicolumn{2}{|c|}{ 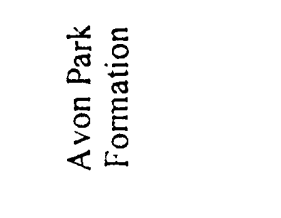 } & \multicolumn{2}{|c|}{ 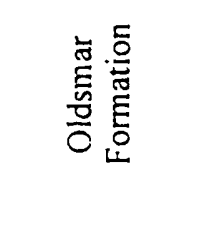 } & \multirow[t]{2}{*}{ 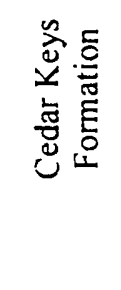 } \\
\hline & & & $\operatorname{dadd} \cap$ & गाрp!W & & & 07 & \\
\hline के & 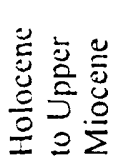 & 荘 & \multicolumn{5}{|c|}{ 芯 } & 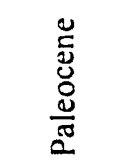 \\
\hline
\end{tabular}


water-bearing zones exist within the Lower Floridan: the upper part of the Lower Floridan aquifer and the Fernandina permeable zone. These zones are separated by a less permeable unit that also restricts the vertical movement of water.

The Upper Floridan aquifer generally corresponds to the Ocala Limestone, and in some areas it also includes the upper part of the Avon Park Formation. The altitude of the top of the aquifer ranges from less than $27 \mathrm{~m}$ below sea level in the extreme southwestern part of St. Johns County to more than $185 \mathrm{~m}$ below sea level in parts of central Duval County. The surface of the Ocala Limestone is a paleokarst plain that exhibits erosional and collapse features that developed before the deposition of the overlying Hawthorn Formation. The base of the Floridan aquifer system generally corresponds to the beginning of the vertically persistent evaporite deposits present in the upper part of the Cedar Keys Formation (Miller, 1986, B-46).

Temperature and water quality varies areally and with depth (Toth, 1990). The Fernandina permeable zone, lowermost zone of the Lower Floridan aquifer (see figure 2), varies from fresh to highly saline (Toth, 1990; Spechler, 1994). Borehole geophysical data and chemical analysis of samples from deep wells that penetrate both the upper and lower waterproducing zones indicate that water mineral concentrations are higher in the upper zone of the Lower Floridan aquifer than in the Upper Floridan (Spechler, 1994; Phelps and Spechler, 1996). Detailed studies of temperature and chemical constituents concentrations at well sites within the study area indicate that elevated temperature and chloride concentrations in the upper Lower Floridan and Upper Floridan appear to be localized, and the area of lateral influence is currently limited in extent (Toth, 1990; Spechler, 1994).

The source for this increased chloride contamination is believed to be from the gradual intrusion of saltwater into fresh water zones of the Upper Floridan aquifer system. There are several possible scenarios to explain the process and path by which saltwater movement is occurring (Spechler, 1994). However, the mechanism that is specifically tested by the seismic reflection surveys presented in this paper involves the upward migration of deeper saline water through breaches (collapse structures, solution pipes, and fracture zones) of semi-confining strata (Spechler, 1994; Phelps and Spechler, 1996). These breach pathways may develop along preexisting geologic discontinuities such as joints, fractures, and faults (see figure 3 ).

\section{Previous Investigations}

\section{HIGH-RESOLUTION SEISMIC REFLECTION METHOD}

Since the mid 1970s high-resolution marine-seismic reflection profiling has been used to acquire good quality data that clearly image dissolution features. This method has been applied offshore in the Atlantic Ocean (Meisburger and Duane, 1976; Sheridan et al., 1981; Popenoe, et al., 1984; Snyder, et al., 1989), and extensively in lakes and rivers (Missimer and Gardner, 1976; Locker, et al., 1988; Snyder et al., 1989; Subsurface Detection Investigation Inc., 1992; Evans, et al., 1994; Kindinger, et al., 1994; Spechler, 1994, 1996; Tihansky, et al., 1996). Typical imaging depths from published lake and river profiles range from 15 to 80 meters. Snyder, et al. (1989), from their examination of marine high-resolution seismic profiles collected on Crooked Lake (central Florida highlands) and St. Johns River in northeast Florida, concluded that at least three distinct types of sinkholes/dissolution features could be identified: "(1) deep, narrow, cylindrical shafts, tens to hundreds of meters wide and tens of meters deep; (2) broad solution valleys showing vertical relief displacements greater than 10 meters stretched across a horizontal 


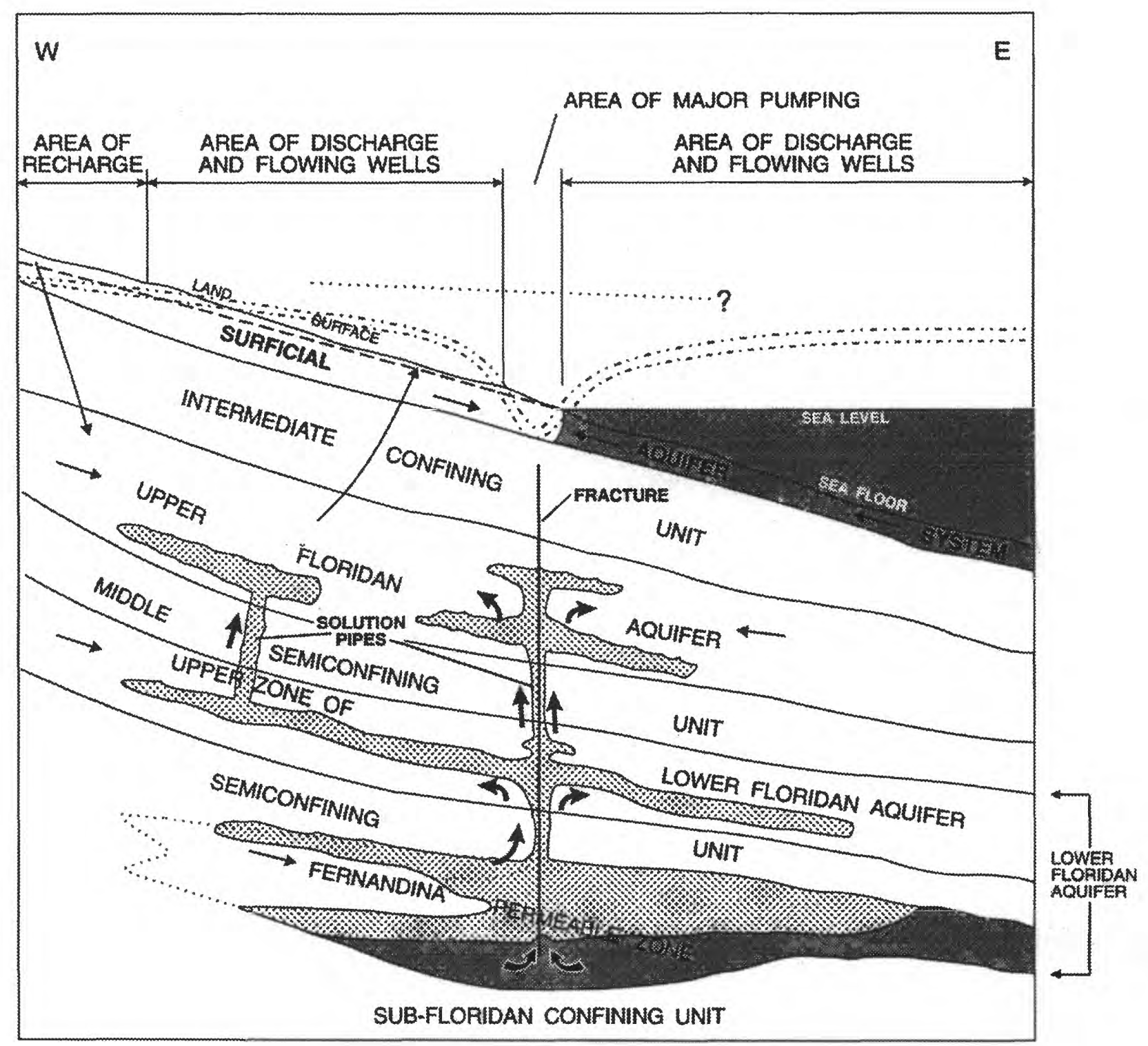

EXPLANATION
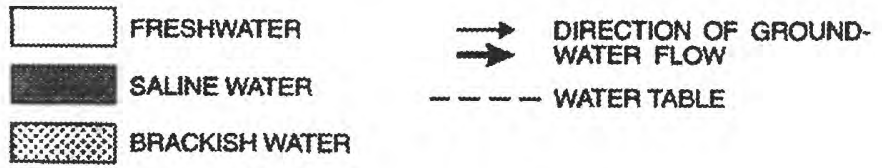

POTENTIOMETRIC SURFACES:

. UPPER FLORIDAN AOUIFEA

$\ldots . . . .$. LOWER FLORIDAN AQUIFER

......... FERNANDINA PEAMEABLE ZONE

Figure 3. Simplified model of the Floridan aquifer system showing a mechanism by which geological discontinuities (fractures, faults, and solution pipes) can provide conduits for the upward migration and mixing of higher chloride concentration water with freshwater (modified from Spechler, 1994, Figure 37). 
distance of 1 to $5 \mathrm{~km}$ (e.g., St. Johns River); and (3) large-scale, cavern-collapse features several hundred meters wide and of undetermined depth."

\section{USGS-SJRWMD (1997) Seismic Acquisition Parameters}

During this study we employed a modified Mini-Sosie high-resolution seismic reflection technique. This technique typically uses three portable, hand-operated, nondestructive earth tampers (Wackers) as a source of random pulse energy. Sensors mounted on the foot plates of each Wacker transmit, by way of backpack-mounted radio transmitters, the exact impact time to the recording truck (Barbier, 1983; Stephenson, et al., 1992). For an individual station, a shot record will contain approximately 1500 correlated and stacked foot plate impacts. At Oakridge well field, lines 2 and 3 were acquired by stacking four impacts of a 10 pound sledgehammer striking a steel plate.

All data were acquired using 28 hertz resonant-frequency geophones and a 60-channel seismograph. Three geophones per receiver group were arranged in a cluster (point) array at each station. Station spacing was generally $5 \mathrm{~m}$ (Oakridge Line 1, Oakridge Lines 4-6, Fort George Island Lines 1 and 2, Bakersville Lines 1 and 2, Tocoi, and Orangedale), with the exceptions of a $2 \mathrm{~m}$ spacing on Oakridge Lines 2 and 3, and a $4 \mathrm{~m}$ spacing on Brierwood Lines 1 and 2. Table 1 summarizes the general acquisition parameters for each seismic line. Data were acquired by "walking on" to a receiver array with the energy source at the beginning of the line, shooting an asymmetric split spread (generally 15 receivers on one side and 45 receivers on the opposite side of the source) through the majority of the line, then "walking off" the receiver spread at the end of the line.

Data processing varied slightly from site to site but generally followed the flows shown in Tables $2 a$ and $2 b$. Migration was not performed on these data because tests on select lines showed that little if any improvement was observed because most of the data are flat lying.

\section{Vertical and Spatial Resolution of Seismic Data}

"High resolution" implies an ability to accurately resolve small or closely spaced features. For seismic reflection studies, Sheriff $(1984$, p. 120) defined high-resolution as "seismic frequencies above the normal exploration range, recorded with the objective of improving resolution, especially of shallow events.... Usually implies frequencies from $75-150 \mathrm{~Hz}$, sometimes to $500 \mathrm{~Hz}$ or higher." The vertical resolution of seismic data is governed principally by frequency content and bandwidth (Berkhout, 1984). As frequency content increases, the minimum observable stratigraphic thickness will decrease, meaning thin beds can be better resolved (Widess, 1973).

In the data acquired with the Wacker and hammer sources, the resolution obtained was nearly the same, varying by about $3 \%$. This frequency content, at approximately $100 \mathrm{~m}$ depth, translates into an average vertical resolution of about $3.7 \mathrm{~m}$ while the spatial resolution averaged about $24 \mathrm{~m}$. This means that a geologic structure, like a collapse feature, would need at least 3.7 $\mathrm{m}$ of vertical offset and be about $24 \mathrm{~m}$ across to be fully imaged. This does not mean smaller features will not be interpretable, because they can still be detected. The difference between resolution and detection is that if a collapse feature is smaller than the resolution limit of the data, the interpretation cannot be significantly quantified nor will the interpretation be unequivocal. In contrast to resolution at $100 \mathrm{~m}$ depth, the approximate resolution at $400 \mathrm{~m}$ depth was generally about $5.5 \mathrm{~m}$ vertically and $70 \mathrm{~m}$ spatially. 
Table 1. Generalized acquisition parameters for high-resolution seismic reflection profiles.

\begin{tabular}{|l|l|l|l|l|l|l|l|}
\hline \multicolumn{1}{|c|}{ Line Name } & $\begin{array}{c}\text { Site } \\
\text { Location } \\
\text { (Figure 1 }\end{array}$ & $\begin{array}{c}\text { Source } \\
\text { Type* }\end{array}$ & $\begin{array}{c}\text { Source } \\
\text { Interval } \\
\text { (meters) }\end{array}$ & $\begin{array}{c}\text { Receiver } \\
\text { Interval } \\
\text { (meters) }\end{array}$ & $\begin{array}{c}\text { Field } \\
\text { Filters } \\
\text { (Hertz) }\end{array}$ & $\begin{array}{c}\text { Sample } \\
\text { Interval } \\
\text { Rate(ms) }\end{array}$ & $\begin{array}{c}\text { Trace } \\
\text { Length } \\
\text { (ms) }\end{array}$ \\
\hline Ft. George Is. 1 & A & Wacker & 5 & 5 & 60 Notch & 1 & 1024 \\
\hline Ft. George Is. 2 & A & Wacker & 5 & 5 & 60 Notch & 1 & 1024 \\
\hline Oak Ridge 1 & B & Wacker & 5 & 5 & 60 Notch & 1 & 1024 \\
\hline Oak Ridge 2 & B & hammer & 2 & 2 & 60 Notch & 0.25 & 512 \\
\hline Oak Ridge 3 & B & hammer & 2 & 2 & 60 Notch & 0.25 & 512 \\
\hline Oak Ridge 4 & B & Wacker & 5 & 5 & 60 Notch & 1 & 1024 \\
\hline Oak Ridge 5 & B & Wacker & 5 & 5 & 60 Notch & 1 & 1024 \\
\hline Oak Ridge 6 & B & Wacker & 5 & 5 & 60 Notch & 1 & 1024 \\
\hline Jacksonville Beach 1 & C & Wacker & 5 & 5 & 60 Notch & 1 & 1024 \\
\hline Jacksonville Beach 2 & C & Wacker & 5 & 5 & 60 Notch & 1 & 1024 \\
\hline Brierwood 1 & D & Wacker & 4 & 4 & 60 Notch & 1 & 1024 \\
\hline Brierwood 2 & D & Wacker & 4 & 4 & 60 Notch & 1 & 1024 \\
\hline Orangedale & E & Wacker & 5 & 5 & 60 Notch & 1 & 1024 \\
\hline Bakersville 1 & F & Wacker & 5 & 5 & 60 Notch & 1 & 1024 \\
\hline Bakersville 2 & F & Wacker & 5 & 5 & 60 Notch & 1 & 1024 \\
\hline Tocoi & G & Wacker & 5 & 5 & 60 Notch & 1 & 1024 \\
\hline
\end{tabular}

"Wacker" is a registered trademark of Wacker Corporation. It is an earth tamper used as a seismic source in this study. Three Wacker units are operated simultaneously during data acquisition. "Hammer" denotes a 10-pound sledgehammer source.

\section{SEISMIC DATA INTERPRETATION}

This section discusses the preliminary interpretations of the high-resolution seismic reflection profiles acquired at seven locations in Duval and St. Johns counties. The data are grouped by relative geographic location (see figure 1 and Table 1) and will be discussed by location. All references to the profile are made by station numbers, which are the approximate source locations on the ground surface. Profiles are presented as depths sections. Depths are determined from the final velocity field which are believed to be accurate within 5\%.

Figure 4 shows an example of the correlation of imaged reflectors with the local northeast Florida stratigraphy, see figure 2. The figure compares the response of the gamma-ray log from Oakridge well field well D-665 (SJRWMD files) with reflector depths imaged on a portion of Oakridge Line 5. Except for small changes in formational thickness between sites, the seismic signature of the formational contacts, and intraformational units, appears to be the same for all sites. The high degree of agreement shown in figure 4 allowed for the interpretation of the approximate tops of the Hawthorn, Ocala, and Avon Park Formations on most of the Mini-Sosie high-resolution profiles. The approximate position of the top of the Oldsmar Formation (below the depth of well D-665 gamma-ray $\log$ ) is based on extrapolated stratigraphic and geophysical log data obtained from the few drill holes that penetrate below the $400 \mathrm{~m}$ depth (SJRWMD files). 
Table 2a. Generalized Processing Flow for All Lines Except Oak Ridge Lines 2 and 3.

\begin{tabular}{|l|l|}
\hline Processing Step & Parameters/Comment \\
\hline Data reformat & Convert from SEG 2 to ProMAX internal \\
\hline Geometry & Install coordinate data into trace headers \\
\hline Trace edit & Kill bad traces, fix polarity reversals \\
\hline Top mute & Zero all data amplitude before and including first arrivals \\
\hline Bandpass filter & $25-50-200-240 \mathrm{~Hz}$ \\
\hline Resample & $1 \mathrm{~ms}$ to $2 \mathrm{~ms}$ \\
\hline AGC gain correction & Adjust amplitudes using 400 ms gain window \\
\hline Elevation statics & Time-shift data traces based on elevation differences \\
\hline Adaptive spiking deconvolution & 120 ms operator length \\
\hline FK filter & Applied on Oak Ridge Line 4 ONLY \\
\hline Sort to CMP & Reorder data by common midpoint number \\
\hline NMO correction & Apply best stacking velocities out 3 analyses \\
\hline Residual statics & Surface-consistent, based on maximum stack power \\
\hline Stack & Zero-offset stack section \\
\hline Poststack processing for Ft. George Island Lines 1,2 \\
\hline Dynamic S/N filter & Non-linear FX \\
\hline Bandpass filter & $25-50-180-240 \mathrm{~Hz}$ \\
\hline Poststack processing for Oak Ridge Lines 1,4,5,6,7,8 \\
\hline Dynamic S/N filter & Non-linear FX \\
\hline Bandpass filter & 25-50-180-240 Hz \\
\hline Adaptive spiking deconvolution & 120 ms operator length \\
\hline Poststack processing for Oak Ridge Lines 9,10, Orangedale, Bakersville 1, 2, Tocoi \\
\hline Eigenvector filtering & 0-40\% eigenimage accepted \\
\hline Final Poststack processing for all lines \\
\hline Time-to-depth conversion & Digital conversion using best stacking velocity \\
\hline
\end{tabular}

Table 2b. Generalized Processing Flow for Oak Ridge Lines 2 and 3.

\begin{tabular}{|l|l|}
\hline Processing Step & Parameters/Comment \\
\hline Data reformat & Convert from SEG 2 to ProMAX internal \\
\hline Geometry & Install coordinate data into trace headers \\
\hline Trace edit & Kill bad traces, fix polarity reversals \\
\hline Top mute & Zero all data amplitude before and including first arrivals \\
\hline Bandpass Filter & $60-120-500-1000$ \\
\hline AGC gain correction & Adjust amplitudes using $100 \mathrm{~ms}$ gain window \\
\hline Elevation statics & Time-shift data traces based on elevation differences \\
\hline Air blast attenuation & Attenuate linear energy at 340 $\mathrm{m} / \mathrm{s}$ \\
\hline NMO correction & Apply best stacking velocities out 3 analyses \\
\hline Residual statics & Surface-consistent, based on maximum stack power \\
\hline Stack & Zero-offset stack section \\
\hline Time-to-depth conversion & Digital conversion using best stacking velocity \\
\hline
\end{tabular}




\section{OAKRIDGE WELL FIELD LINE 5}

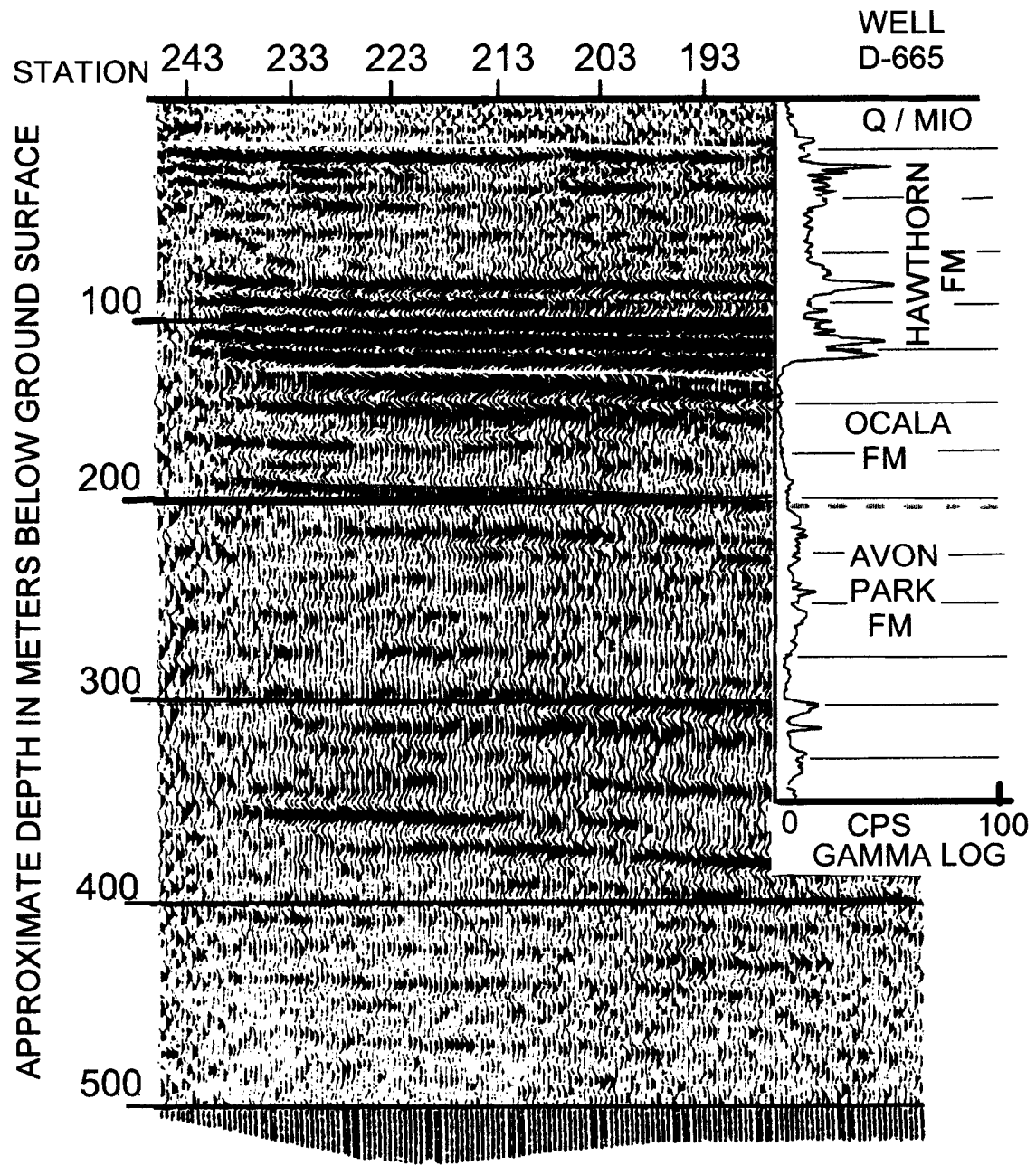

Vertical exaggeration 1:1

Figure 4. This figure shows an example of the stratigraphic correlation between gamma-ray logs (i.e. well D-665) and seismic reflection data (i.e. Oakridge Line 5) imaged in northeastern Florida. Top of Hawthorn Formation is highlighted in pink, top of Ocala Limestone is highlighted in orange, and top of the Avon Park Formation is highlighted in green. 
On the interpreted profiles, colored line highlights are used to indicate reflectors representing formational boundaries (pink for the top of the Hawthorn Formation, orange for the top of the Ocala Limestone, green for the top of the Avon Park and purple for the Oldsmar Formation). On some of the profiles, strong intraformational reflectors are highlighted (yellow within the Hawthorn and blue within the Avon Park). Uninterpreted seismic reflection profiles can be found in the appendix section.

\section{Site A: Fort George Island}

Two high-resolution seismic reflection profiles were acquired on Fort George Island (Site A, figure 1) in an area where increased chloride concentrations have been detected and mapped, see figure 5a. The upper and basal contacts of the Hawthorn Formation and the Ocala Limestone are imaged reasonably well on these profiles. Stratigraphic correlation is based on gamma-ray logs from wells D-3841, D-0913, and D-164 (SJRWMD files). The quality of the data at Fort George Island is generally very good because of little cultural noise, although ground conditions (thick organic layer) within the forest and on an abandoned golf course appeared to cause some problems (induced noise) due to areas of poor receiver and source coupling.

\section{Fort George Island-Line 1}

Line 1 was acquired from south-to-north along a dirt road and through densely forested areas. The most dramatic feature imaged in these data is a buried collapsed sinkhole above a solution pipe between stations 162 and 210 (see figure 5b). Reflectors within the upper Hawthorn Formation, as shallow as $40 \mathrm{~m}$, show evidence of downwarping and displacement (approximately $25 \mathrm{~m}$ of vertical subsidence between stations 162 and 210) as the interbedded carbonate, clay and silt strata deforms (sags) plastically downwards over a deeper solution pipe. The shallowest horizontal reflections within this subsidence structure are believed to represent Holocene sedimentation. The Hawthorn/Ocala contact is downwarped at least $10 \mathrm{~m}$ across this feature.

Beneath the downwarped Hawthorn strata, the profile exhibits a distinct vertical zone (stations 165 to 190) of non-coherent reflectivity (washout). This zone (marked by red lines on figure $5 \mathrm{~b}$ ) clearly passes through the limestone and dolomite lithology of the Ocala Limestone and Avon Park Formations (note truncated blue reflectors) to a depth of at least $375 \mathrm{~m}$ (limit of seismic reflection data). Discontinuous reflector "packets" within the washout zone (solution pipe) are probably caused by blocks of less soluble material like limestone and back scatter from the irregular solution pipe walls.

\section{Fort George Island-Line 2}

Line 2 was acquired east-to-west and crossed Line 1 at station 117 (station 192 of Line 1), see figure $5 \mathrm{c}$. The quality of the data of Line 2 was slightly lower than on Line 1 possibly due to poorer ground coupling of the Wacker sources and geophones caused by soft soil and the thick organic materials encountered within the forested areas. The effect of poor coupling is most evident at depth where the Ocala/Avon Park contact reflector is not as clearly imaged on the west side of the profile. The Hawthorn/Ocala contact, however, is clearly imaged and shows an apparent subsidence of almost $40 \mathrm{~m}$. Displacement and disruption of the Hawthorn Formation strata is prevalent between stations 160 to 200. Within the limits of the aforementioned sinkhole, it appears that a second sinkhole has developed between stations 120 and 137 . Further, there 


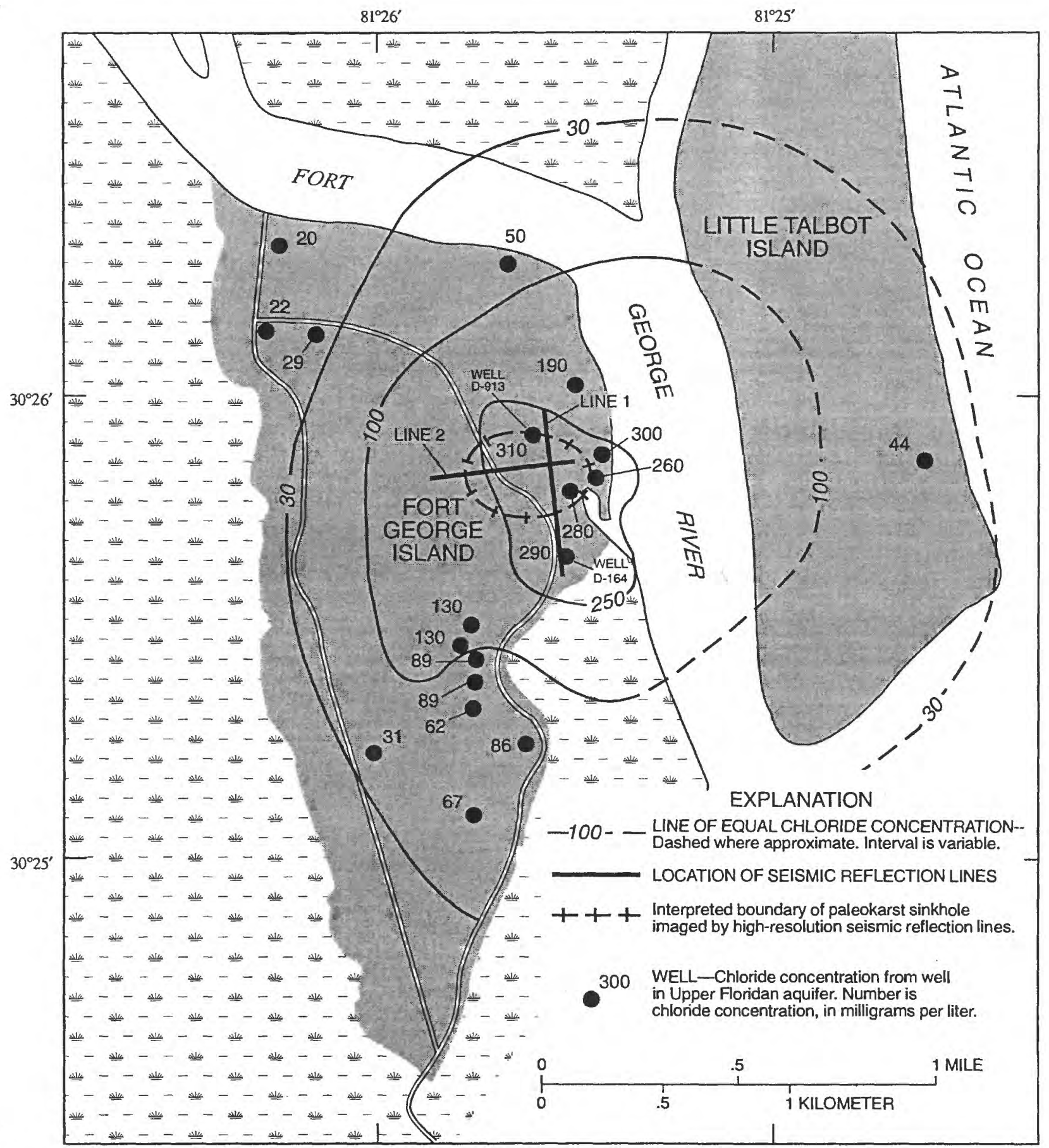

Figure 5a. Location of high-resolution seismic reflection profiles on Fort George Island with respect to equal chloride concentration contours. Note the correlation of wells with high levels of chloride to the buried solution pipe (heavy crossed line) interpreted from the seismic reflection profiles (modified from Spechler, 1994). 


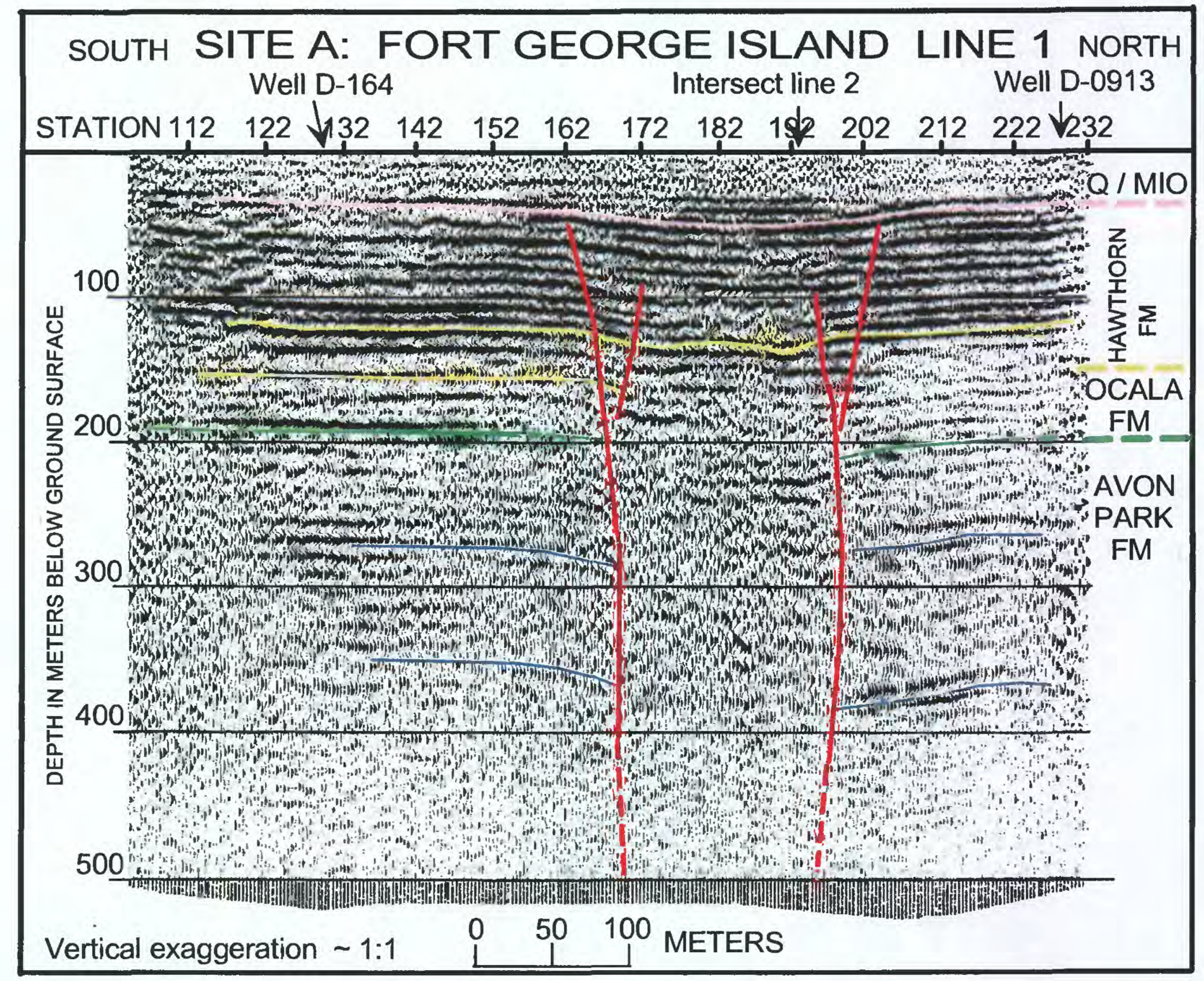

Figure 5b. Interpretation of Fort George Island line 1 high-resolution seismic reflection profile, see figures 1 and $5 a$ for location. A vertical solution pipe (between red lines) extends from the bottom of the profile into the Hawthorn Formation. Note downdipping and truncated intraAvon Park Formation reflectors (blue). Deformed and offset reflectors (yellow and pink), defining the boundary of a buried sinkhole which is collapsing into the solution pipe, are imaged to within $40 \mathrm{~m}$ of the surface. 


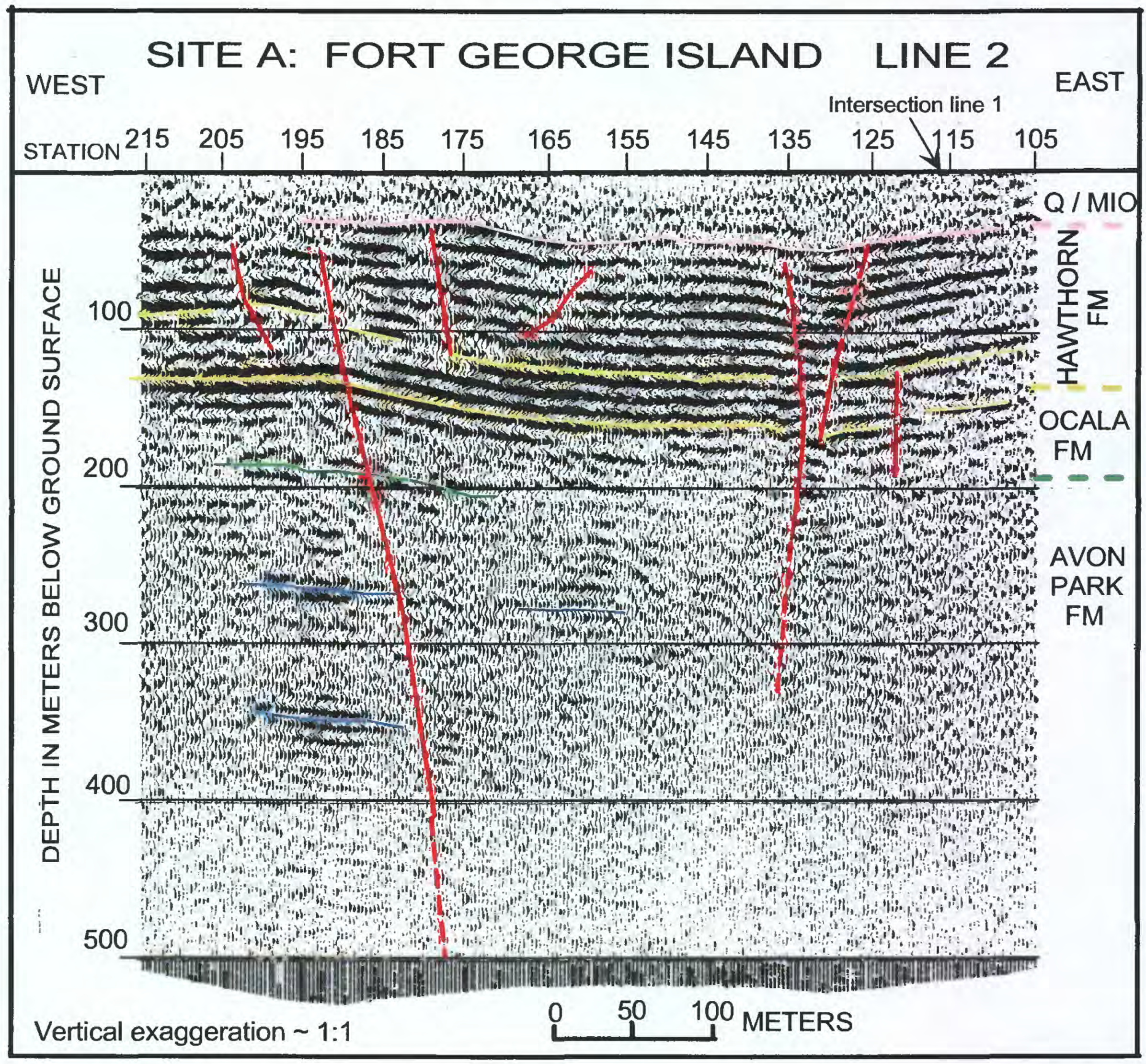

Figure 5c. Interpretation of Fort George Island Line 2 acquired from east to west perpendicular to Fort George Island line 1, see figures 1and 5a for location. The profile images downwarped reflectors (pink, yellow, orange) and offset (short red lines) reflectors (beginning at approximately station 200 and continuing beyond the east end of the profile) that are associated with the buried sinkhole imaged on line 1. It is unclear whether or not the eastern boundary of the solution pipe is defined by the fracture (red) identified beneath stations 130 to 135 or if the boundary is east of station 105. 
appears to be a secondary zone of subsidence between stations 117 to 137 . This secondary zone is approximately bounded on the west side by a fracture zone (red lines beneath station 130 to135 on figure 5c) that extends beneath the imaged Ocala/Hawthorn contact.

On the west side of the profile, between stations 185 to 200 , the western boundary (wall) of the solution feature (washout zone) is well defined by the flexure and truncation of reflectors (blue highlighted reflectors on figure 5c) ranging in depth from 200 to $375 \mathrm{~m}$. It is not clear whether the fracture zone beneath stations 103 to 135 marks the eastern edge of the solution pipe or if the pipe wall lies on the edge or beyond the east end of the line. Near-surface (40-140 m) deformed strata continue beyond the east end of the profile although the deformed reflectors (i.e. yellow, figure 5c) on the east end of the profile (station 105) are only $10 \mathrm{~m}$ deeper than their original depth west of station 200.

Collectively, Fort George Island Lines 1 and 2 clearly image a downwarped buried sinkhole over a solution pipe. Deformation clearly extends to a depth of $380 \mathrm{~m}$ which is the limit of seismic penetration on this profile (figure 5b). Therefore, it is possible that the solution pipe also penetrates into the Oldsmar Formation whose contact is believed to be 425 to $450 \mathrm{~m}$ in depth. The depth of penetration of this solution feature is significant because it appears to breach the middle semi-confining unit within the Avon Park Formation and possibly the Oldsmar Formation whose top represents the top of the semi-confining unit that separates the Upper zone of the Lower Floridan aquifer from the underlying and more saline Fenandina permeable zone (see figure 2). The approximate interpreted limits of strata deformation of this collapsing buried sinkhole is estimated to measure about $200 \mathrm{~m}$ by at least $475 \mathrm{~m}$. The location of this feature is plotted (heavy dashed line) on figure 5a with respect to wells and contours representing levels of chloride concentration in the Upper Floridan aquifer. A good correlation exists between the location of the seismically imaged sinkhole-solution pipe and the highest levels of chloride concentrations measured in the Fort George Island wells.

\section{Site B: Oakridge Well Field}

Six high-resolution seismic reflection profiles were acquired in the vicinity of the Oakridge well field (figures 6a-g). Four profiles (Lines 1, 4, 5, and 6) were acquired using Wacker energy sources and two (Lines 2 and 3) were acquired using a 10-pound sledgehammer source (Table 1). The data quality at the Oakridge well site is generally quite good with the exception of noise from occasional heavy traffic along Alden Street and from well field pump motors.

\section{Oakridge Well Field Line 1}

These data reveal a series of flat-lying reflectors that correlate nicely with nearby well lithology (well D-665; figures 4 and 6a). These data clearly image the Quaternary/ Hawthorn contact (pink highlight) at about 15 to $20 \mathrm{~m}$ depth, the Hawthorn/Ocala contact (orange highlight) at about $145 \mathrm{~m}$, the Ocala/Avon Park contact (green highlight) at about $200 \mathrm{~m}$ and possible reflectors associated with the top of the Oldsmar Formation (purple) at approximately $450 \mathrm{~m}$ (figure 6b). On the western end of the profile, between station 191 and 205, dipping reflections from 50 to $100 \mathrm{~m}$ depth are probably coherent noise and not from a geologic structure.

No collapse or downwarping of Hawthorn reflectors are seen in this profile. However, two small zones (red arrows on figure 6b) of reflection discontinuity, between stations 126 to 130 and 140 to 145 , occur in the otherwise strong and continuous reflectors that mark the contact of 

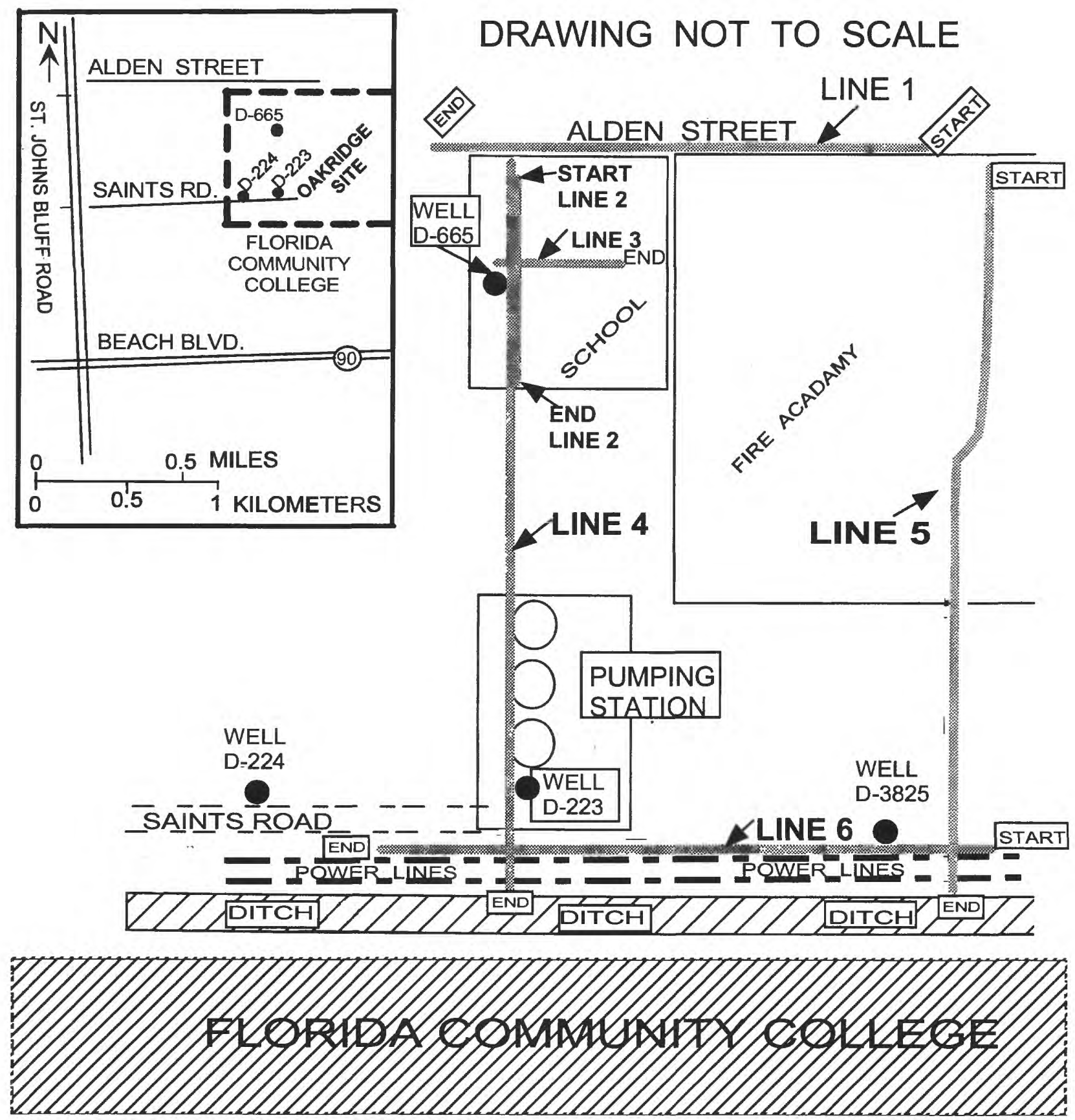

Figure 6a. Map of Oakridge well field (Site B) showing the relative locations of wells and six high-resolution seismic reflection lines.. See Table 1 for data acquisition parameters for these lines. Well D-665 was removed from service in 1994 because chloride concentration in the water at the wellhead had increased to $690 \mathrm{mg} / \mathrm{l}$ (Spechler, 1996). 


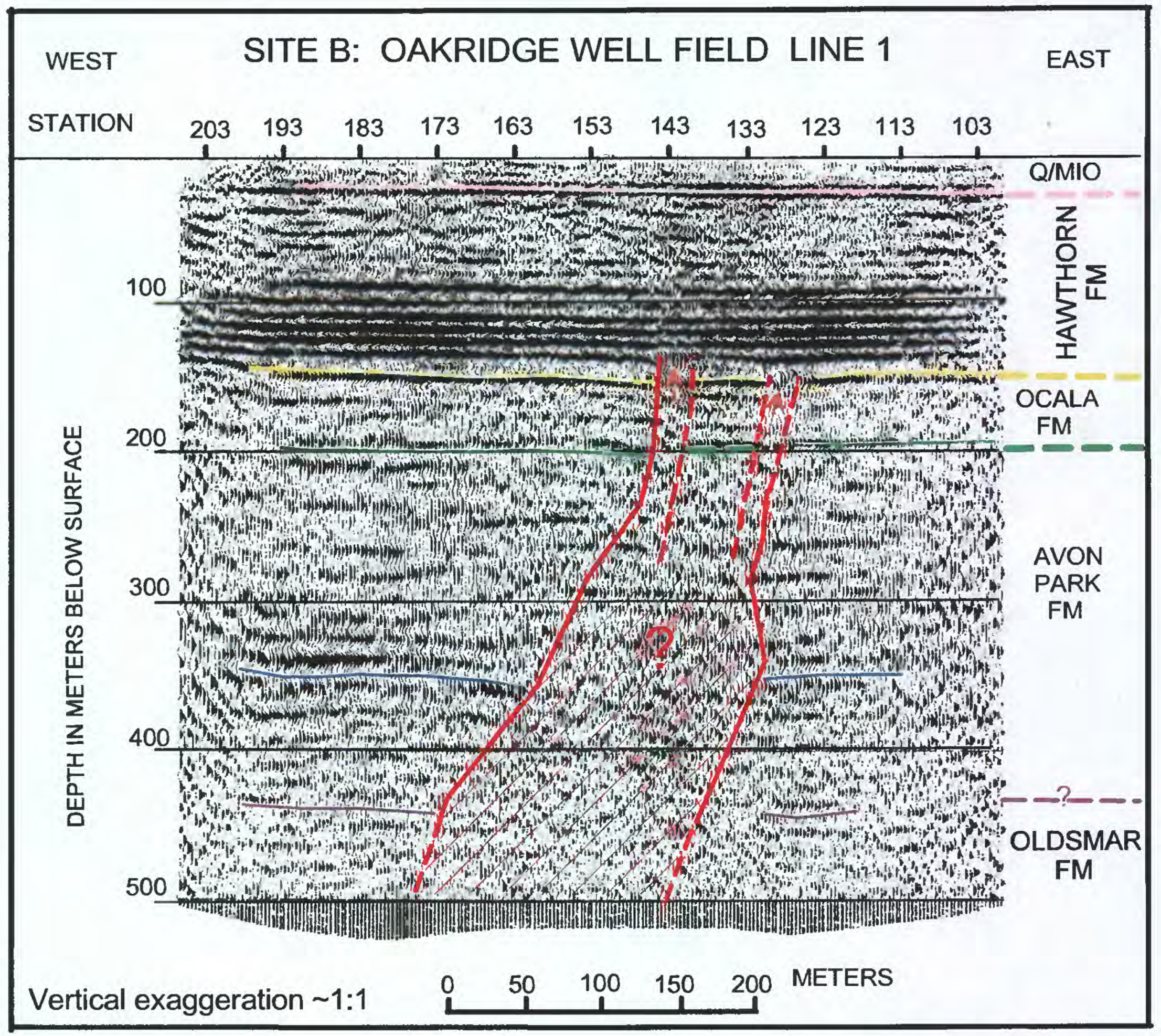

Figure $6 \mathrm{~b}$. Interpretation of Oakridge well field line 1 acquired from east to west along Alden Street, see figures 1 and $6 a$ for location. Low frequency zones (red arrows) between stations 126 to 130 and stations 140 to 145 , that disrupt the Hawthorn/ Ocala contact reflector, are interpreted to be small solution pipes and/or paleo-sinkholes. Red hatched area is a solution pipe. 
the Hawthorn and Ocala Formations. We interpret these two zones, approximately $25 \mathrm{~m}$ wide, to be paleosinkholes that possibly formed on the karst plain surface of the Ocala Formation and/or solution cavities/pipes that may connect to deeper solution features.

A deeper washout zone (red hatched area on figure), similar to the one imaged by Fort George Island Lines 1 and 2, is imaged between stations 133 and 163. This feature which extends from an approximate depth of 275 to $300 \mathrm{~m}$ to the bottom of the profile is defined by sharply truncated reflectors (blue highlighted) to the west and east of the feature. It is not clear but the two aforementioned zones imaged as reflector discontinuities at the top of the Ocala Formation may connect with this deeper feature. The significance of this feature is that it appears to breach the middle semi-confining unit between the Upper and Lower Floridan aquifers (figure 2). Additionally, if the top of the Oldsmars Formation (purple highlight) is between 425$475 \mathrm{~m}$ depth, this solution feature could also be breaching the semi-confining unit between the upper zone of the Lower Floridan and the Fernandina permeable zone. The interpreted feature is in close proximity to well D-665 which was removed from service because the chloride concentration in water at the wellhead had increased to $690 \mathrm{mg} / \mathrm{L}$ in 1994 (Phelps and Spechler, 1996). Drill logs for well D-665 noted that a cavity filled with soft, sandy limestone was encountered at a depth of $360 \mathrm{~m}$ (Phelps and Spechler, 1996).

\section{Oakridge Well Field Line 2}

This hammer-source profile (figure $6 \mathrm{c}$ ) has $1 \mathrm{~m}$ trace spacing and is centered about well D-665 (figure 6a). The Quaternary/Hawthorn and the Hawthorn/Ocala contacts are clearly imaged (figure 6c). Strong evidence of deformation is not observed in these data. A subtle downwarp of upper Hawthorn reflectors (30-40 m depth) from station 101 to 135 is noticeable but does not appear in the deeper Hawthorn strata. At this point, the significance, if any, to this feature is not known.

\section{Oakridge Well Field Line 3}

The data quality of this hammer-source profile (figure 6d) is lower than that of Line 2, even though the shooting parameters (Table 1) and general location were the same. Based on the generally horizontal appearance of the reflections on Lines 1 and 2, as well as other lines in this area, the sharp $5 \mathrm{~m}$ downwarp visible (i.e. pink and yellow reflectors) between stations 110 and 135 may indicate the presence of a dissolution feature (figure 6d). If this is correct, these data probably are imaging one edge of such a feature.

\section{Oakridge Well Field Line 4}

These Wacker-source data image the Quaternary/Hawthorn contact and the Hawthorn/Ocala contact, but the Ocala/Avon Park contact is not clearly imaged (see figure 6e). Data quality is generally good, with the exception of the region near the operating well pumps between stations 1110 and 1140 . Pump noise was mostly removed by an additional processing step known as F-K filtering (Table 2). Line 4 overlies Line 2 between stations 1001 and 1057 (figure 6a). On the south end of the profile, strong reflectors at 220 and $260 \mathrm{~m}$ depth appear to be sharply truncated and disappear beneath Station 1128. These reflectors reappear beneath Station 1108 and, although not strong, they can be traced to the north end of the profile. We speculate that signal degradation related to well pump noise may be the reason for reflector loss 


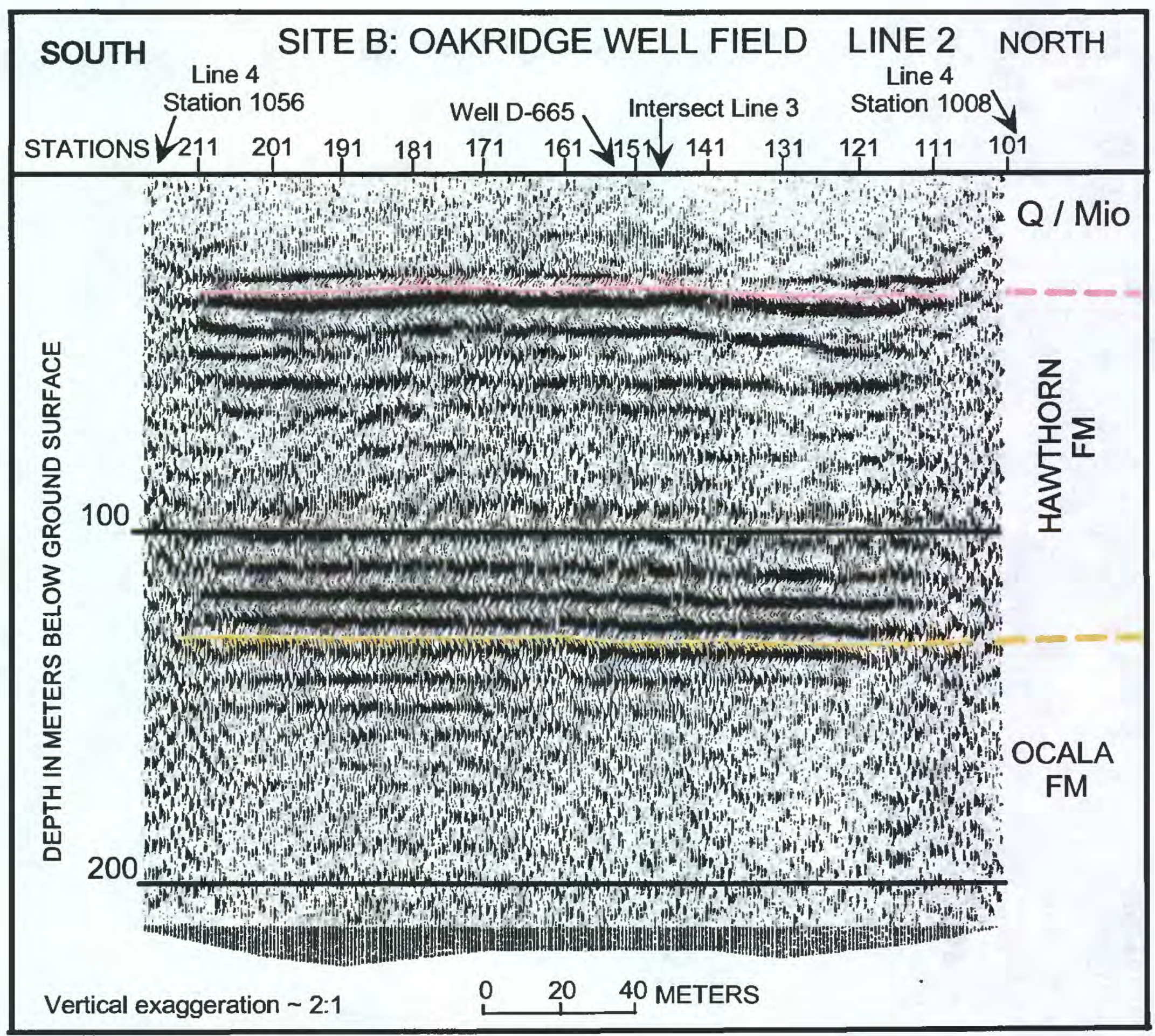

Figure 6c. Interpretation of Oakridge well field line 2 acquired with a $10 \mathrm{lb}$ sledgehammer energy source and with a $2 \mathrm{~m}$ geophone spacing. See figures 1 and $6 a$ for line location. 


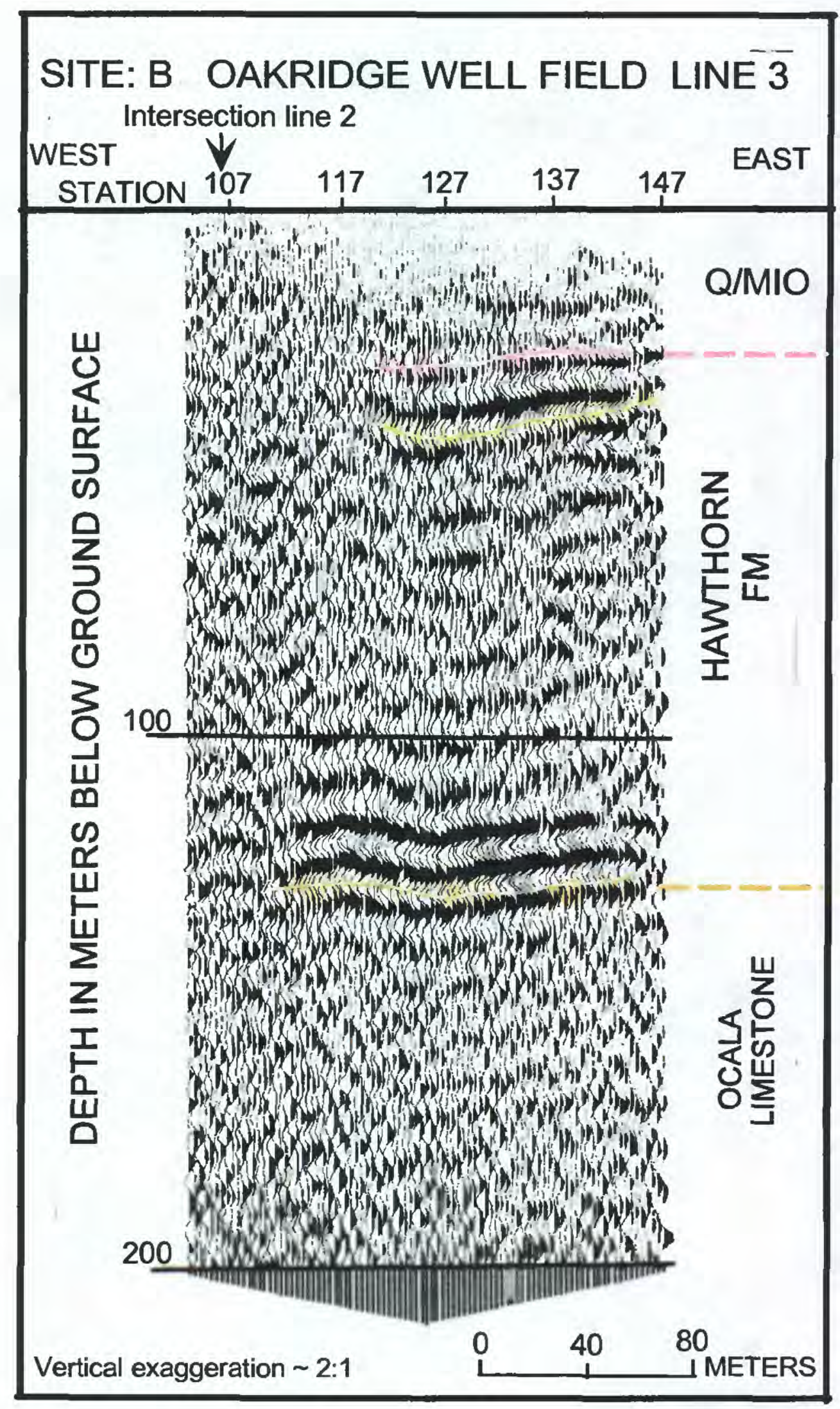

Figure $6 \mathrm{~d}$. Interpretation of Oakridge well field Line 3 acquired perpendicular to Oakridge well field lines 2 and 4 , see figure 1 and $6 a$. Note downwarp of pink, yellow, and orange reflectors beneath station 127. 


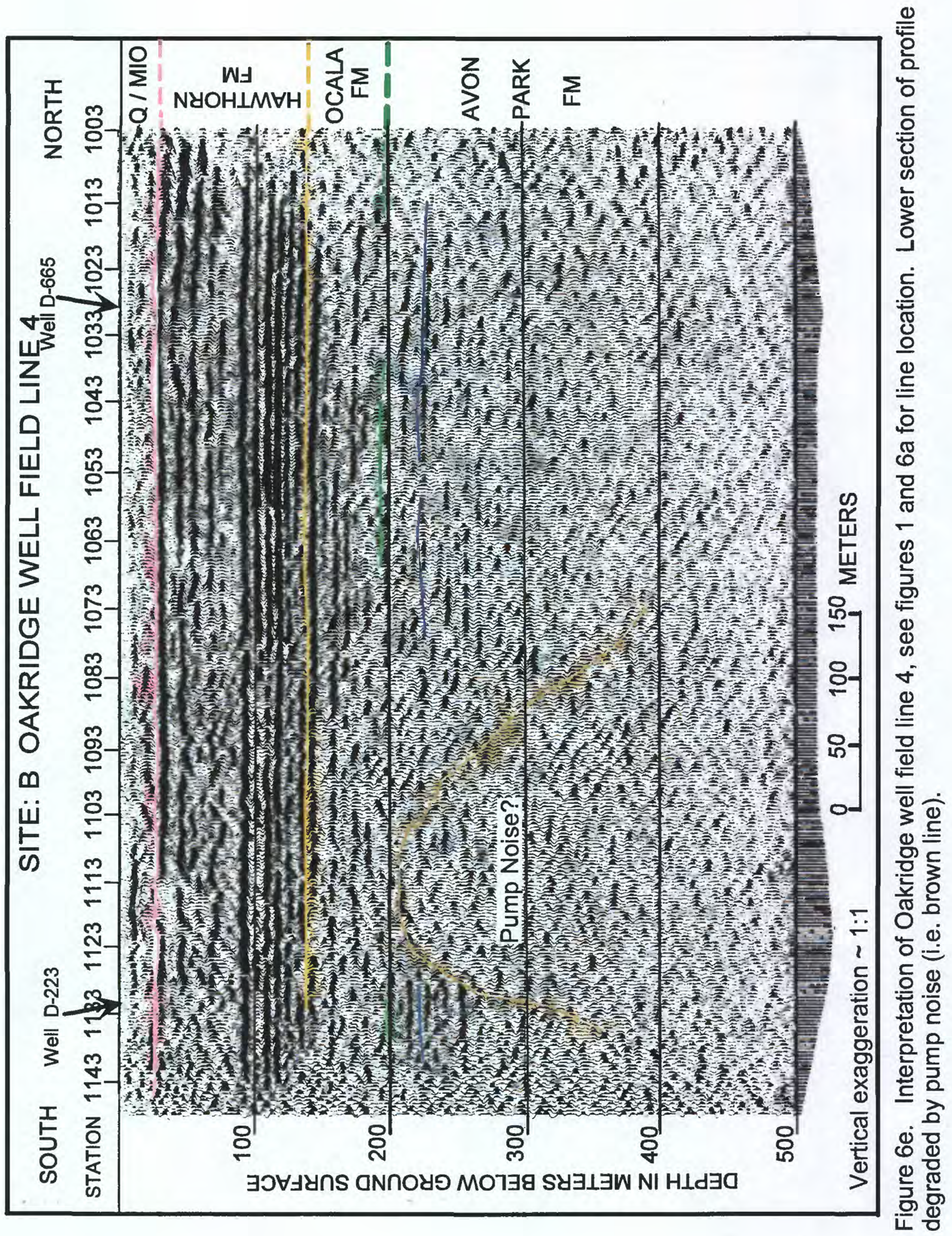


in this area. Because the data quality is poor below $300 \mathrm{~m}$, it is difficult to interpret any deep structure with certainty.

\section{Oakridge Well Field Line 5}

These Wacker-source data are the highest quality (best signal-to-noise ratio) obtained in this area, clearly imaging reflectors to depths of up to $450 \mathrm{~m}$ (see figure $6 \mathrm{f}$ ). This profile clearly shows the Quaternary/Hawthorn contact (pink) at about 15-to-20 m depth, the Hawthorn/Ocala contact (orange) at about 130 to $140 \mathrm{~m}$, and the Ocala/Avon Park contact (green) at about $200 \mathrm{~m}$ depth. Overall, reflectors show a general northward dip of about 3 degrees.

There is loss of coherence and deformation of the otherwise strong reflector that defines the Hawthorn/Ocala contact (orange) between stations 150 and 180 that we interpret as the top of a solution pipe that extends to the bottom of the profile. This disruption is larger and more pronounced than the disruption seen at a similar depth on Oakridge well field Line 1. This loss of reflector amplitude and coherence is nearly identical in appearance to the seismic reflection signature of water and rubble filled coal mine voids imaged by Steeples and Miller (1987).

Between stations 155 and 180, between 200 to $300 \mathrm{~m}$ depth, is a washout (less reflective) zone. Beneath this zone, deeper strong reflectors (blue highlighted) within the Avon Park and possibly the Oldsmar Formation (purple highlighted) approximately $450 \mathrm{~m}$ depth are imaged on both sides of this wash-out zone. Reflectors between 325 and $350 \mathrm{~m}$ depth, that appear to cross this zone, show amplitude attenuation and are discontinuous. Outside of the washout zone, the deeper reflectors exhibit slightly opposing dip angles so that they appear to be dipping in toward the washout zone. Based upon the spatial position of the disrupted reflectors marking the Hawthorn/Ocala contact and the lower washout zones, it is probable that all three are connected and a part of the same solution feature.

\section{Oakridge Well Field Line 6}

Data quality is generally poorer than on Line 5 due to strong noise from operating well pumps and the overhead power lines, which degraded the signal (see figures $6 \mathrm{a}$ and $6 \mathrm{~g}$ ). Between stations 140 and 165, the loss of amplitude and coherency within the reflector package that defines the Hawthorn/Ocala contact (approximately 125 to $130 \mathrm{~m}$ depth), may be attributable to noise of the operating pumps. However, the signature of this zone is very similar in character, width (approximately $150 \mathrm{~m}$ ) and depth to the reflector discontinuity imaged on the nearby and relatively quiet Line 5 (figures $6 \mathrm{a}$ and $6 \mathrm{f}$ ). Additionally, the same reflector sequence and the overlying reflectors closer to the well pumps are not disrupted or degraded.

Similar to what was seen in Line 5 (figure 6f), strong reflectors (blue) within the 200 to $450 \mathrm{~m}$ depth interval appear to be truncated on either side of a washout zone between stations 140 and 170 . Within the zone are hints of broken and contorted reflections which are believed to be associated with irregular block surfaces and walls within the broader washout zone. It appears that the reflector disruption at the base of the Hawthorn Formation and this lower washout zone are a single solution feature. Based on the similarity in size and type of the solution features imaged on Lines 5 and 6 , we speculate that they may be the same feature.

Collectively the Oakridge well field lines image several solution features whose imaged depth of penetration is well within the lower Avon Park and possibly into the Oldsmar Formations. Such solution pipes could be acting as conduits by which the upward migration of deeper, warmer and more saline water are allowed to mix with fresher water. The feature imaged 







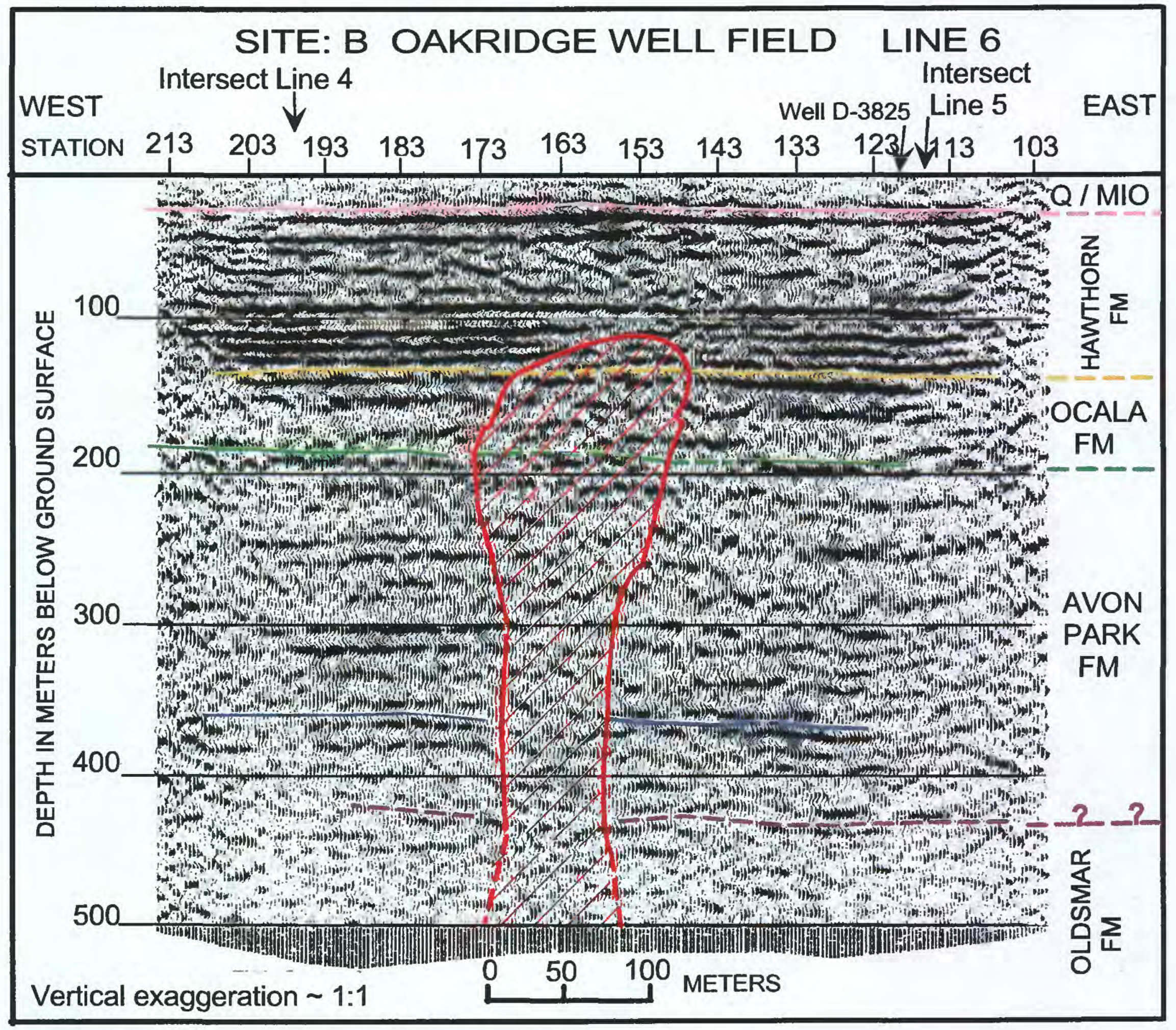

Figure $6 \mathrm{~g}$. Interpretation of Oakridge well field line 6 , see figures 1 and $6 \mathrm{a}$ for location. Coherence loss between stations 143 to 163 may represent deformation of lower Hawthorn/ upper Ocala Limestone strata. Note truncated intra-Avon Park (i.e. blue) and Oldsmar (?) (purple) reflectors. A near vertical solution pipe appears to extend from the base of the section to at least the Ocala/Hawthorn Formation contact. 
on Line 1 (figure 6b) is in close proximity to well D-665 which has the highest measured chloride concentration in the Oakridge well field. The next highest chloride concentration values are recorded from well D-3825 (figure 6a) which is near the intersection of Lines 5 and 6.

\section{Site C: Jacksonville Beach}

Two Wacker-source seismic reflection profiles were acquired in the city of Jacksonville Beach (figures 1 and 7a-c). The data quality in Jacksonville Beach is generally average because of cultural noise from automobile traffic, poorer geophone coupling, and power lines. We interpret the Hawthorn/Ocala contact (orange highlight) and the Ocala/Avon Park contact (green highlight) on both seismic profiles. The reflector correlation of these horizons was accomplished using the gamma-ray log from well D-484 (SJRWMD files).

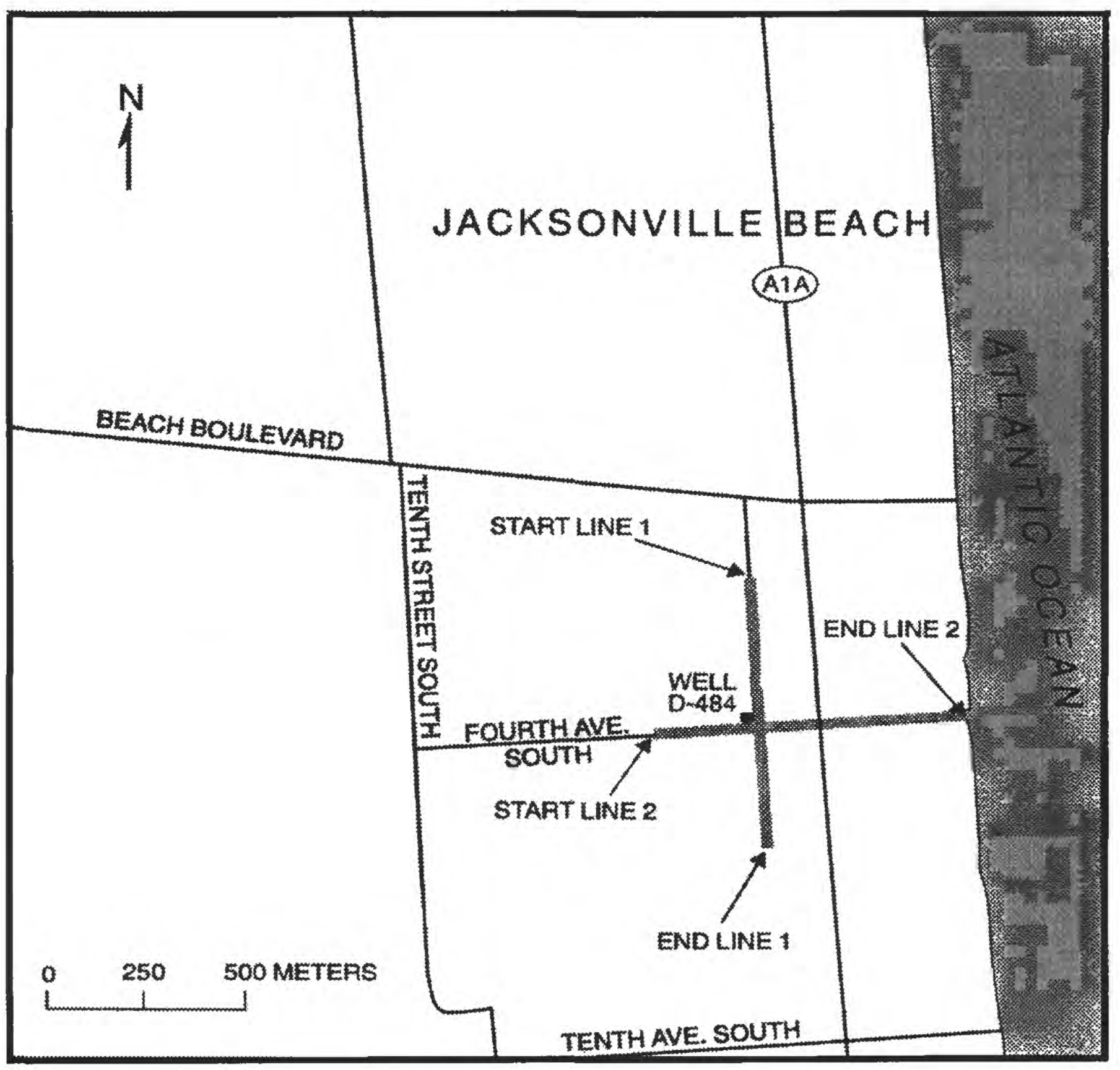

Figure 7a. Location of high-resolution seism ic reflection lines at Jacksonville Beach, Florida (Site C, figure 1). 
Jacksonville Beach Line 1

These data (figure $7 \mathrm{~b}$ ) were acquired north-to-south on $4^{\text {th }}$ Street S. from $1^{\text {st }}$ Avenue S. to south of $6^{\text {th }}$ Avenue S., crossing just to the east of well D-484 (station 187). Reflector Q/MIO and reflectors throughout the Hawthorn Formation show a slight downwarp between stations 135 and 180. Maximum deformation is approximately $5 \mathrm{~m}$ beneath station 158 . Beneath station 141 reflectors within the Hawthorn Formation appear to change dip angle and may mark the northern boundary of the downwarping mentioned above. Hawthorn Formation reflectors between 50 and $125 \mathrm{~m}$ depth are broken and change dip angle possibly indicating fracture zones beneath stations 115 and 125 . Between stations 144 and 173 , within the downwarped area identified above, the signature of the reflectors in the depth range of 70 to $95 \mathrm{~m}$ change (amplitudes become less coherent). Another smaller region of reflector signature change is imaged between stations 183 and 193 at a depth of 60 to $80 \mathrm{~m}$. These two pockets (red hatched area on profile) exhibit seismic characteristics similar to those imaged by reflection profiles that crossed water and rubble filled voids in a coal mine (Steeples and Miller, 1987). Beneath station 163, at a depth of approximately 300 to $360 \mathrm{~m}$, there appears to be a zone (red hatched oval) of non-reflectance. The aforementioned pockets of low to non-reflectance may represent cavities and/or solution features. Sonic televiewer logs of well D-484 indicated several well-defined voids (probable solution features) at a depth of 347 to $351 \mathrm{~m}$ (Phelps and Spechler, 1997). Currently the significance, if any, of this observation is unknown.

\section{Jacksonville Beach Line 2}

Acquisition of this line required the shooting and merging of two separate profiles as well as an undershoot of Highway A1A. Data quality is fairly good, even with heavy traffic (figure 7a). While there appears to be an upwarp and reflection discontinuity between stations 188 and 215 , this also coincides in part with the location of A1A and may be adversely affected by heavy traffic on the highway (figure 7c). However, the disruption of the reflections may also indicate some geologic discontinuity. Other more likely geologic structures are found between stations 163 and 210 where evidence of several near-vertical fracture zones are imaged. These washout zones are about $25 \mathrm{~m}$ wide and can be traced to a depth of at least $400 \mathrm{~m}$. Additionally, a seismic wave form (diffraction hyperbola) that commonly indicates a nearby bed termination (i.e. fault or highly fractured area) occurs beneath stations 183 to 193 . This section of data is similar to a section of marine data acquired by Evans, et al. (1994) that is interpreted to have multiple closely spaced and discontinuous solution pipes. 


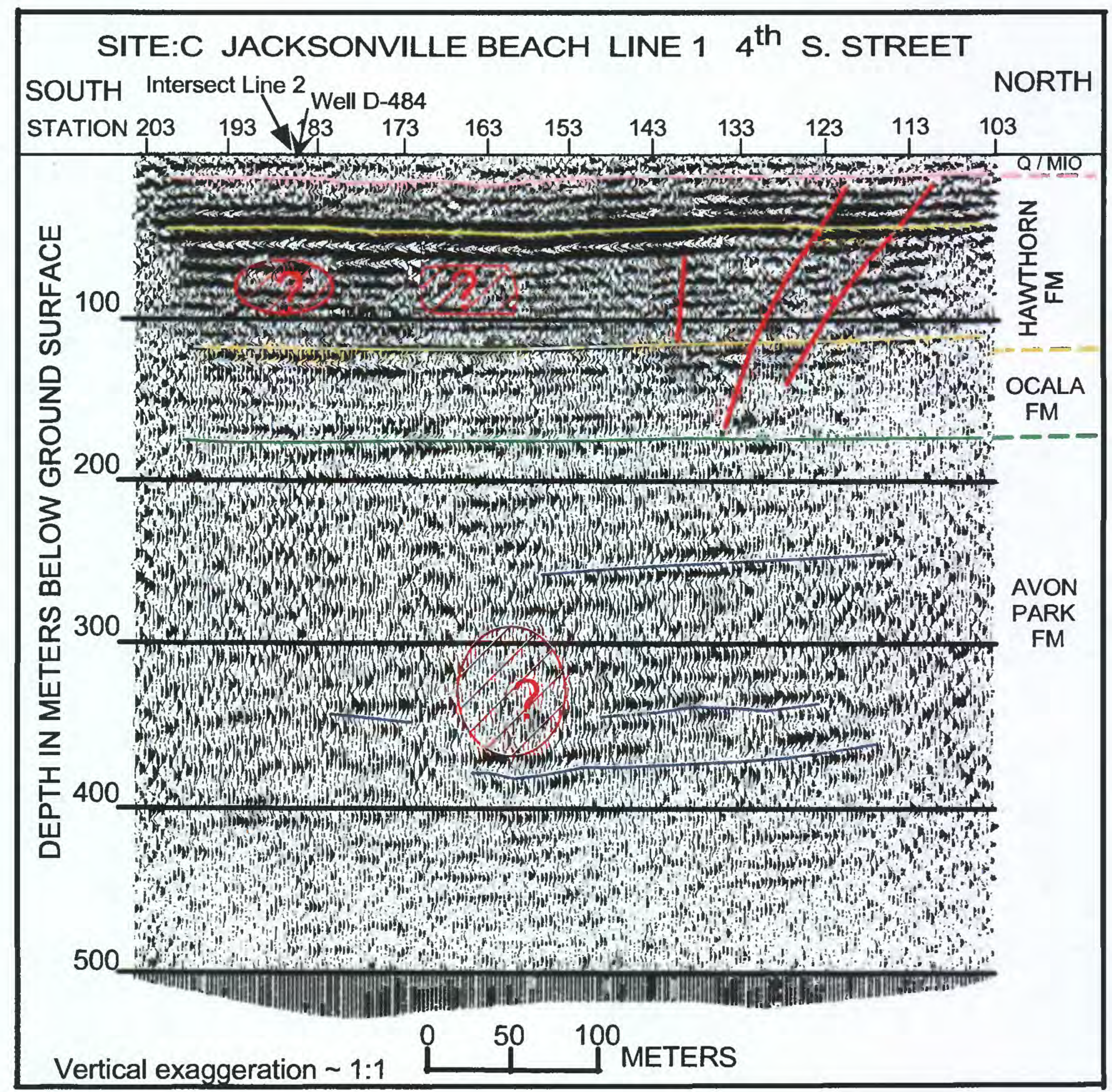

Figure 7b. Interpretation of Jacksonville Beach line 1, see figures 1 and $7 a$ for line location. There is approximately 4-5 $\mathrm{m}$ of downwarping of near-surface strata (yellow intra-Hawthorn reflector) and Hawthorn reflectors appear to be displaced along fracture zones (red lines) on the north side of the profile. Red ovals (i.e. stations 183 to 193,65 to $90 \mathrm{~m}$ depth), identifying areas where strong reflectors are missing, may represent dissolution cavities. 


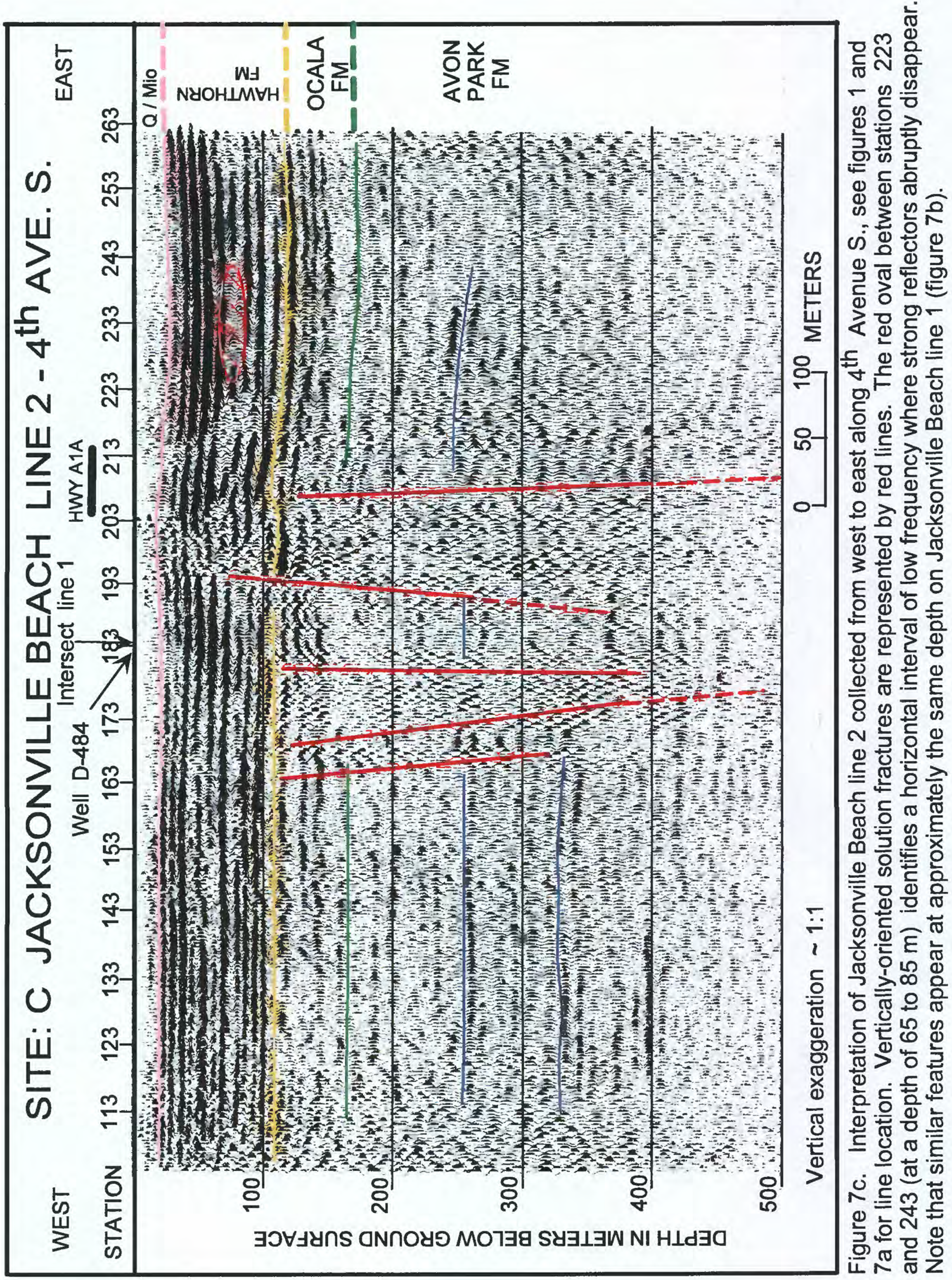




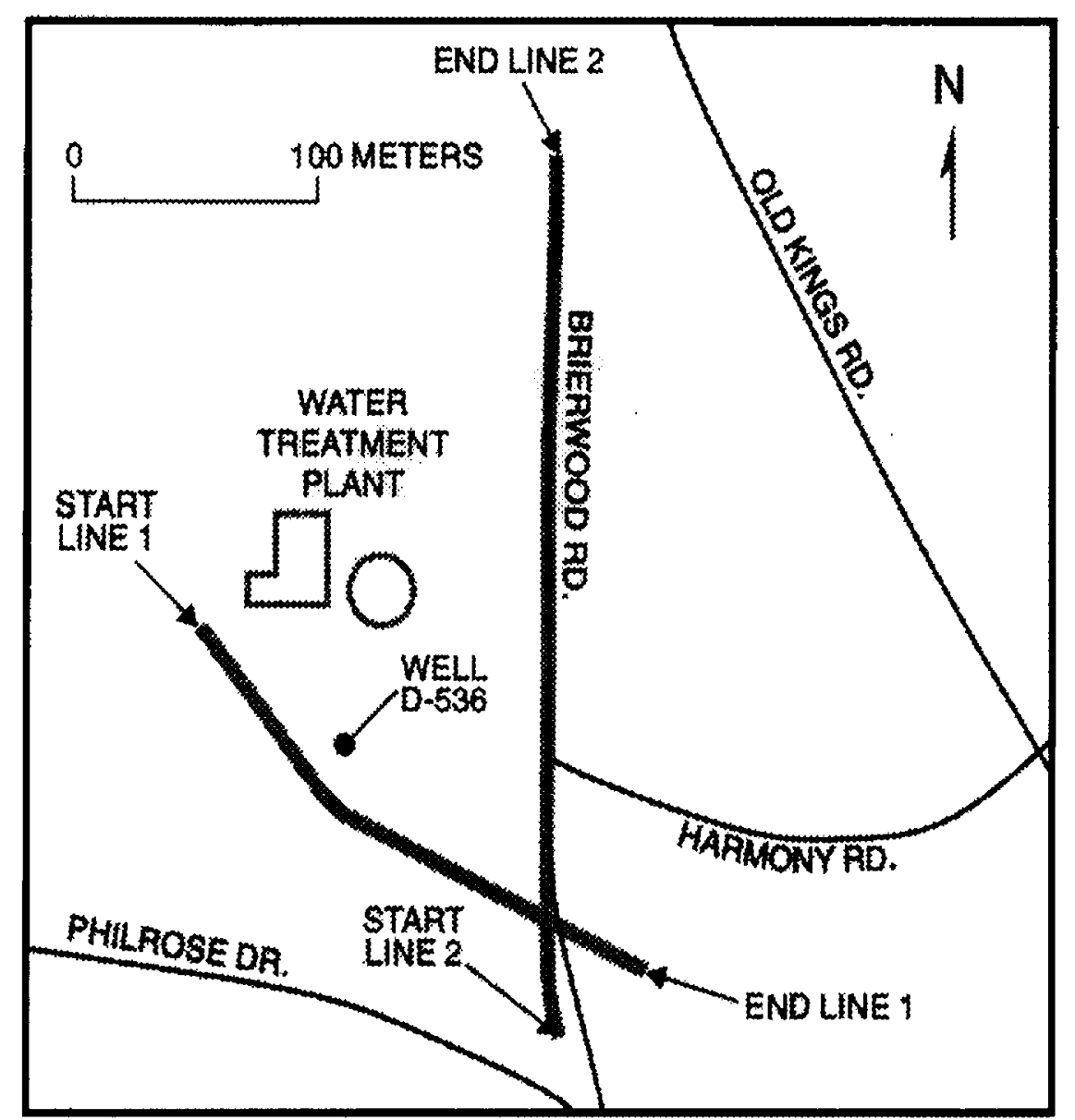

Figure 8a. Location of high-resolution seism ic reflection lines at Brierwood water treatment plant (Site D, figure 1).

\section{Site D: Brierwood}

The Quaternary/Hawthorn, Hawthorn/Ocala, and Ocala/Avon Park contacts are imaged on the two Brierwood profiles (figures 1 and $8 \mathrm{a}-$ c). Stratigraphic correlation is based on gamma logs from well D-536 (SJRWMD files). Both profiles were acquired using the Wacker sources. Receiver spacing was $4 \mathrm{~m}$ (1 meter less than typically used) to better fit into the space available for data acquisition (Table 1). The data quality at Brierwood is generally good even with presence of some cultural noise including an operating well pump (figure 8a).

\section{Brierwood Lines 1 and 2}

On Line 1 reflectors are imaged to a depth of approximately $350 \mathrm{~m}$ (figure $8 \mathrm{~b}$ ). The Quaternary/Hawthorn contact is not clearly imaged. The Hawthorn/Ocala (orange highlight) and Ocala/Avon Park (green highlight) contacts are imaged but do not cross anything interpretable as a dissolution feature. However, reflectors are visibly dipping to the eastward, suggesting warping after deposition of the Hawthorn Formation. Reflections on Line 2 are all generally flatlying and show no apparent structure (figure 8c).

We speculate that the Brierwood data were acquired on the flank of a larger dissolution feature that has developed after deposition of the Hawthorn (figure 8b). If these two profiles were, in fact, acquired on the flank of a large sinkhole, the horizontal orientation of reflections on the Line 2 profile (figure 8c) may indicate that it was acquired essentially along the strike of the speculated dissolution feature. 


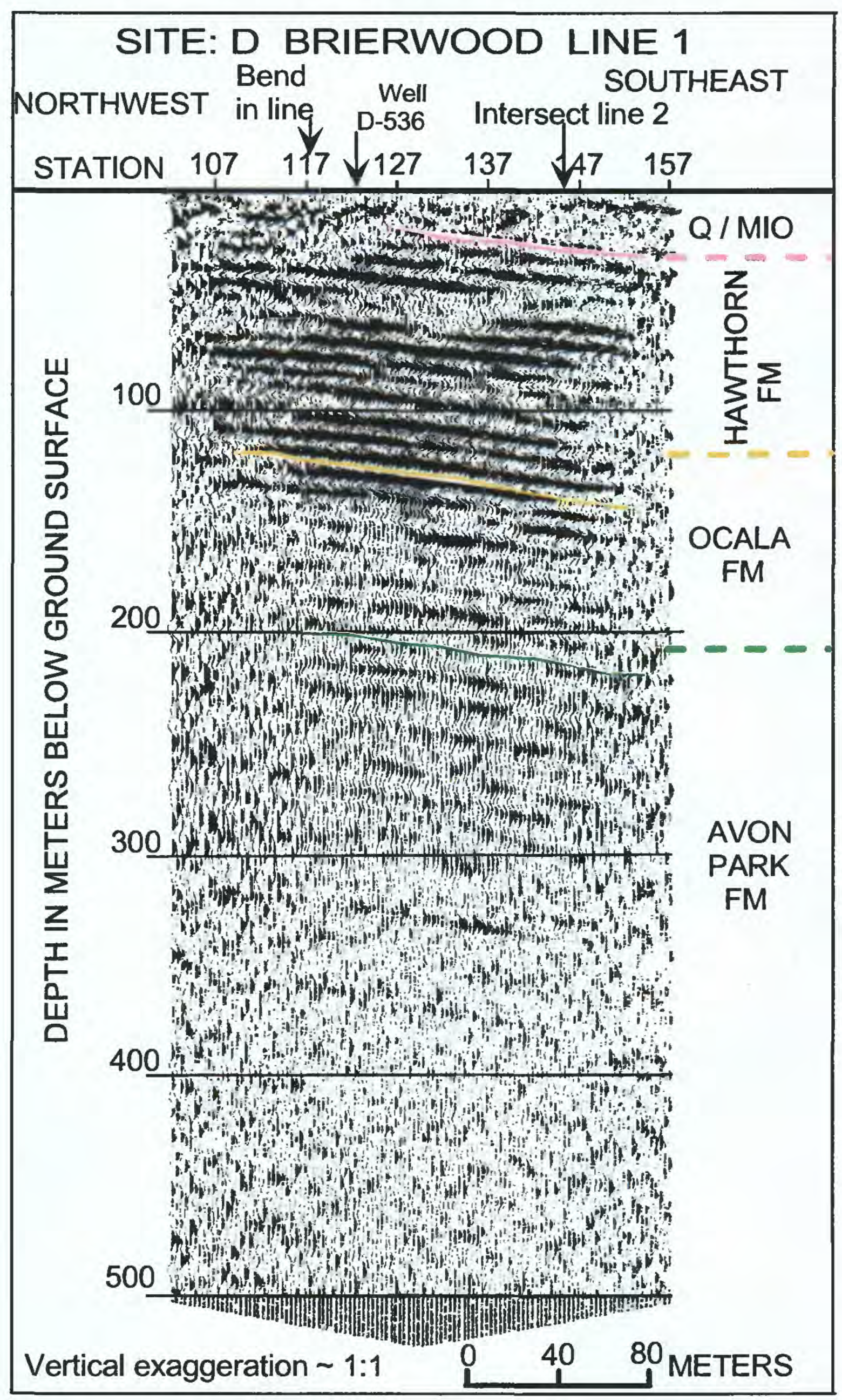

Figure $8 \mathrm{~b}$. Interpretation of Brierwood line 1 acquired near the Brierwood water treatment plant, see figures 1 and 8 a. Formational contact depths are from well D-536 geophysical logs. All reflectors show a consistent dip to the southeast. 


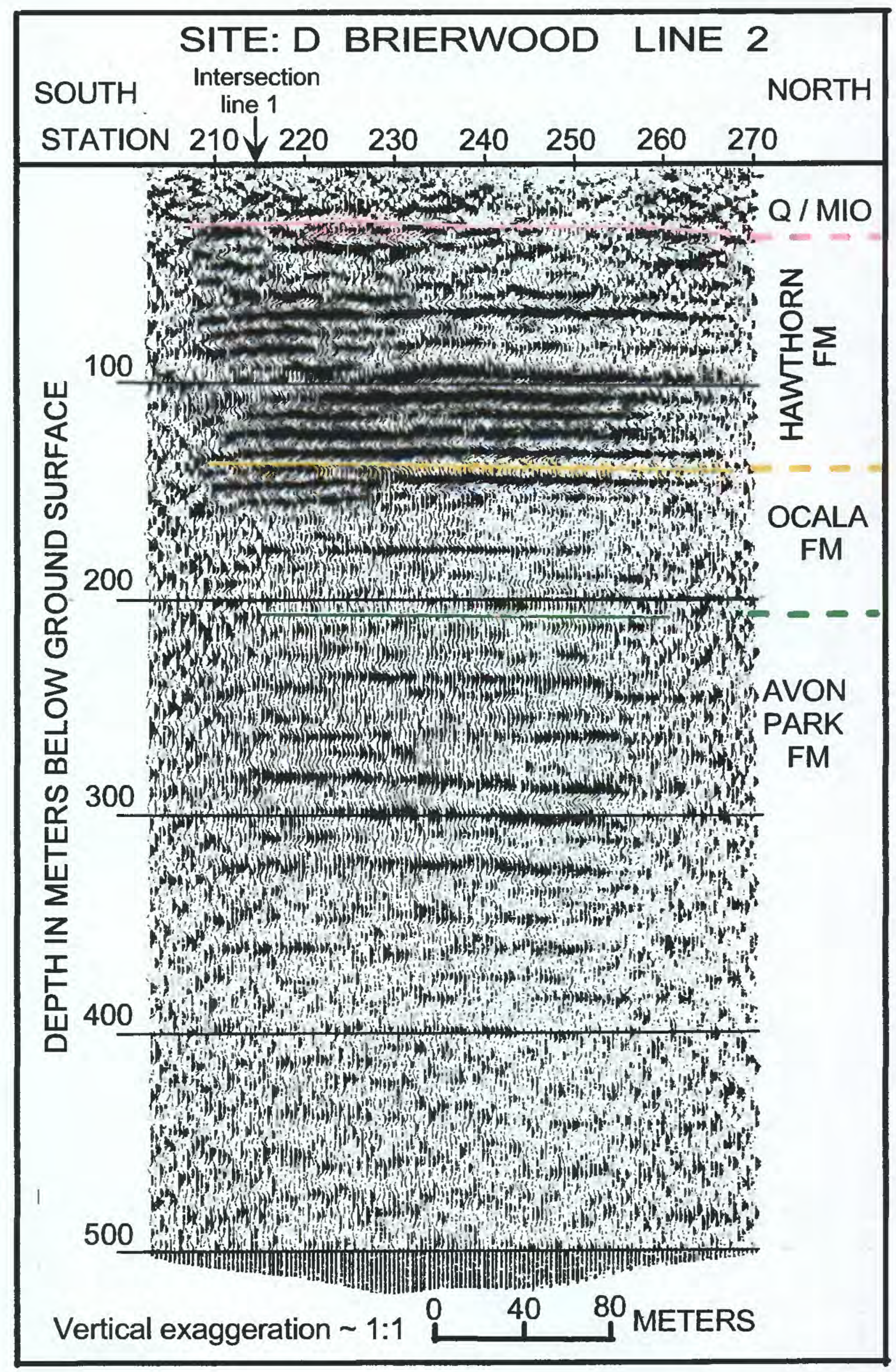

Figure 8c. Interpretation of Brierwood line 2, see figures 1 and $8 a$ for line location. This line was acquired at approximately 70 degrees to line 1. Note the horizontal strata imaged by this profile. The apparent dip to the southeast shown on line 1 may represent the northwest flank of a large collapse feature. 


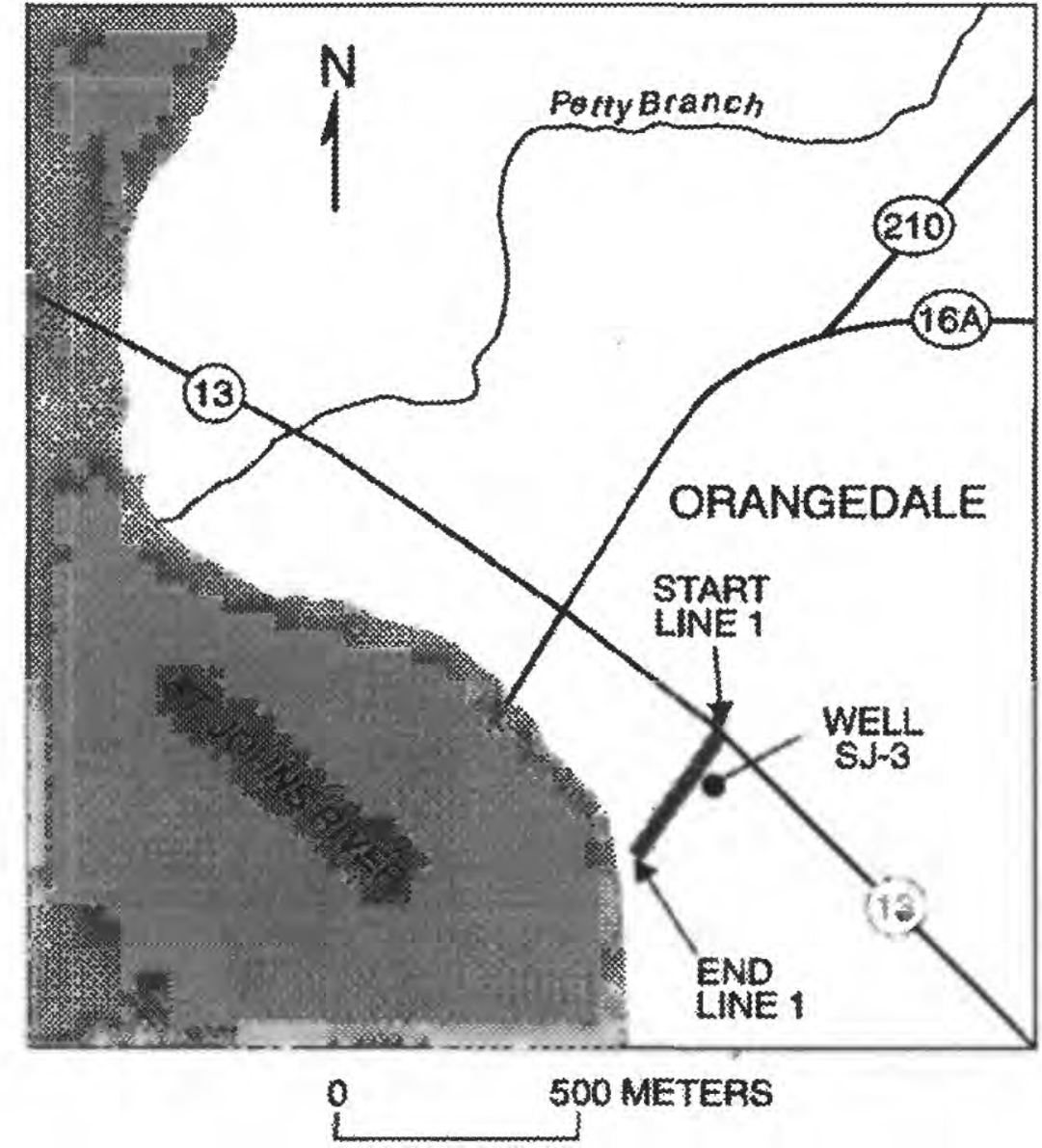

Figure 9a. Location map for the high-resolution seismic reflection line near Orangedale, Florida (Site E, figure 1).

\section{Site E: Orangedale Line 1}

Line 1 was acquired between Florida State Highway 13 and the St. Johns River (figure 9a). The interpreted Hawthorn/Ocala (orange highlight) contact and an intra-Hawthorn (yellow highlight) reflector are imaged reasonably well on this profile (figure 9b). No well logs from the investigated well were available for precise stratigraphic correlation. This profile was acquired using the Wacker sources with a receiver spacing of 5 meters (Table 1). The data quality at Orangedale is good primarily because of the quiet location.

The most significant feature imaged on this profile is a shallow zone of downwarped reflectors (i.e. yellow figure 9b) to the southwest (toward the St. Johns River), beginning at about station 125. Deformation seems to be restricted to reflectors within the Hawthorn and does not seem to continue into the Ocala Formation. The geologic process responsible for the downwarping deformation of reflectors on the southwest end of this profile is unclear. Marine seismic surveys in the St. Johns River, approximately $3 \mathrm{~km}$ south of this site, revealed several solution collapse features with one feature having a width of approximately $140 \mathrm{~m}$ and vertical subsidence of nearly $10 \mathrm{~m}$ (Spechler, 1996). 


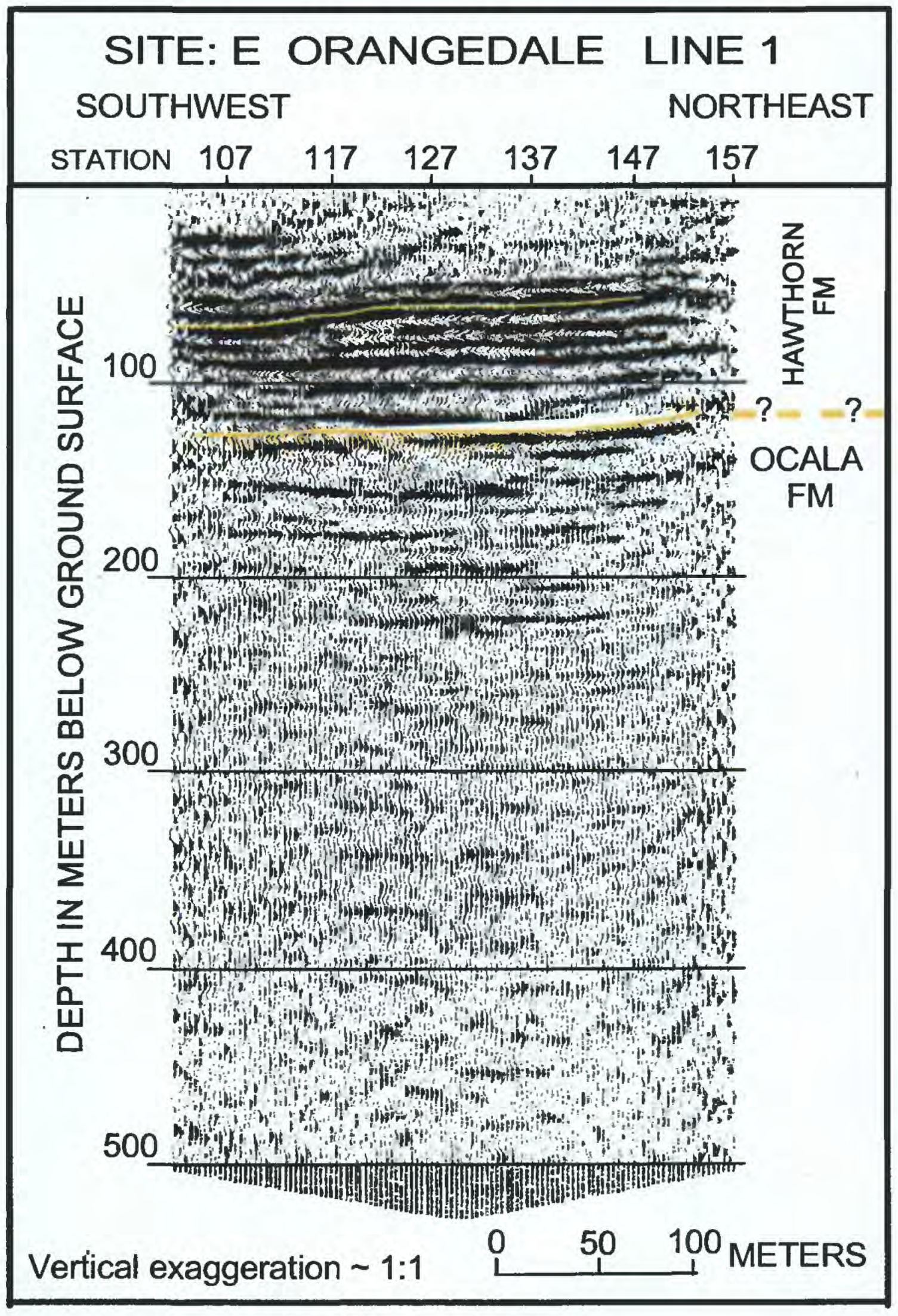

Figure 9b. Interpretation of Orangedale line 1, see figures 1 and $9 a$ for line location. Note downwarping of upper Hawthorn strata (i.e. yellow intra-Hawthorn reflector) on the southwest end of the line. The St. Johns River is approximately $50 \mathrm{~m}$ southwest of station 107. 


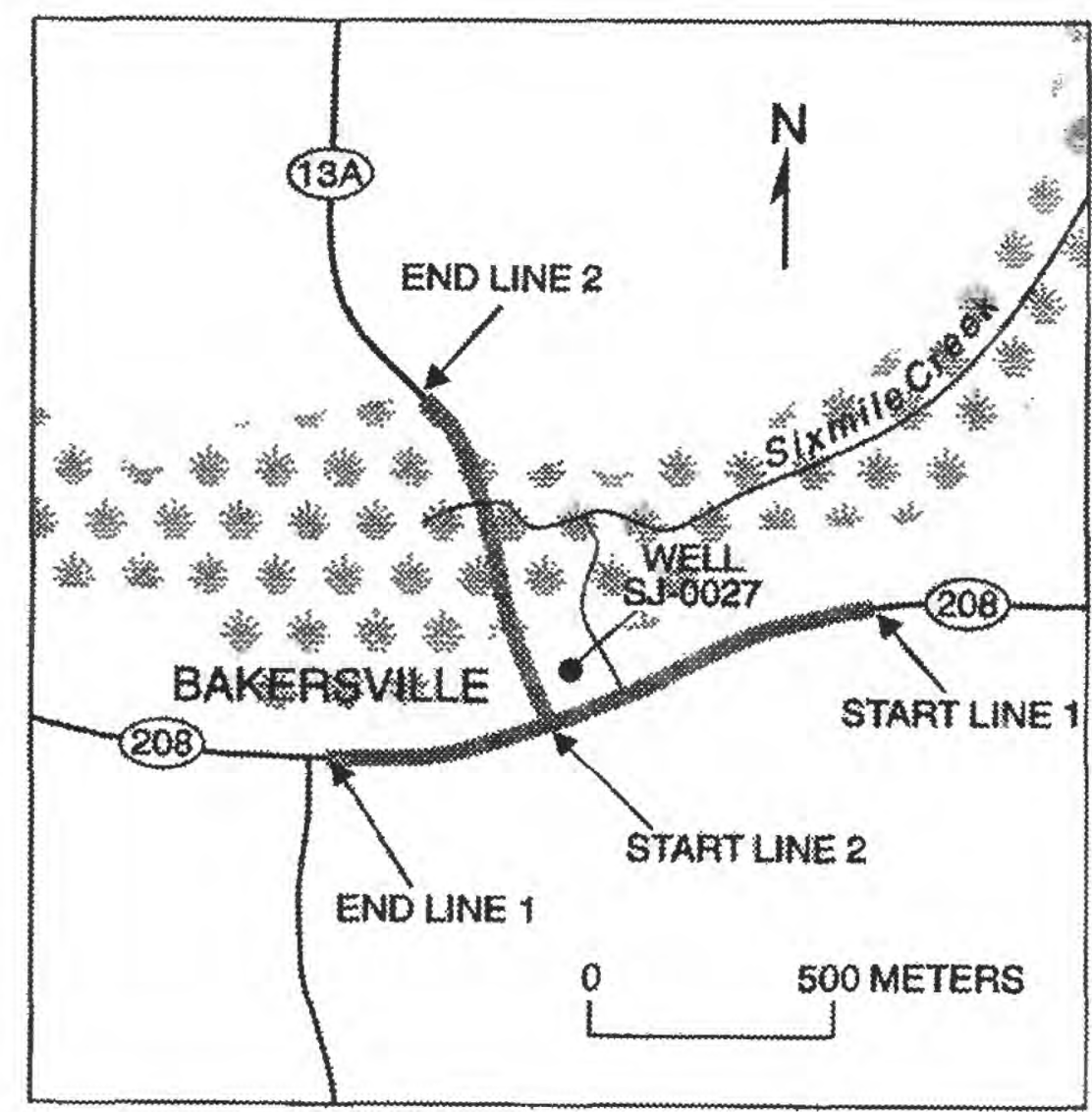

Figure 10a. Location map of high-resolution seismic reflection lines at B akersville, Florida (Site F, figure 1).

\section{Site F: Bakersville}

Two Wacker-source highresolution seismic reflection profiles were acquired at Bakersville (figures 1 and 10 a-c). The Hawthorn/Ocala and Ocala/Avon Park contacts are imaged on these profiles. The Quaternary/Hawthorn contact was not imaged because it is too shallow in this area for the acquisition parameters used. Stratigraphic correlations interpreted on figure $10 \mathrm{~b}$ are based on gamma-ray log data obtained from well SJ-0027 (SJRWMD files). The data quality at Bakersville site is generally good on Line 1 (figure 10b) even though there were periods of heavy automobile traffic during acquisition. For unknown reasons, signal quality was noticeably lower on Line 2 (figure 10c).

\section{Bakersville Line 1}

Figure $10 \mathrm{~b}$ shows the profile of Bakersville Line 1 which was acquired east-to-west along Florida State Highway 208. These data do not show any obvious structures that are interpretable as dissolution features. However, two areas (red hatched ovals) do have some characteristics that may be associated with pockets of dissolution. Beginning at station 225 , there is a flexure point where all reflectors are downwarped to the northeast. There is approximately $13 \mathrm{~m}$ depth difference for reflectors beneath station 103 compared to there original position on the southwest side of the profile.

\section{Bakersville Line 2}

This survey was acquired south-to-north along Florida State Highway 13A (figure 10c). Station 501, the south end of Line 2, was at the same location as station 267 of Line 1. Part of the data were acquired across a bridge between stations 580 to 589 . The data obtained beneath the bridge are of a different appearance because of a decrease in subsurface coverage due to a loss of near-source offsets.

The reflection packages on the two lines at the profile intersection between the approximate depths of 30 and $175 \mathrm{~m}$ match very well. But, proceeding north of station 550 , the reflections on Line 2 (figure 10c) downwarp and appear more undulated out to the bridge. North of the bridge, comparison of the reflection package on Line 1 with Line 2 match only after a downward shift of the Line 1 reflection package of approximately $15 \mathrm{~m}$. This downwarp appears to be a collapse feature because it occurs before the drop in data fold caused by the bridge and because the reflection packages of Line 1 match so well with the reflection package of Line 2 


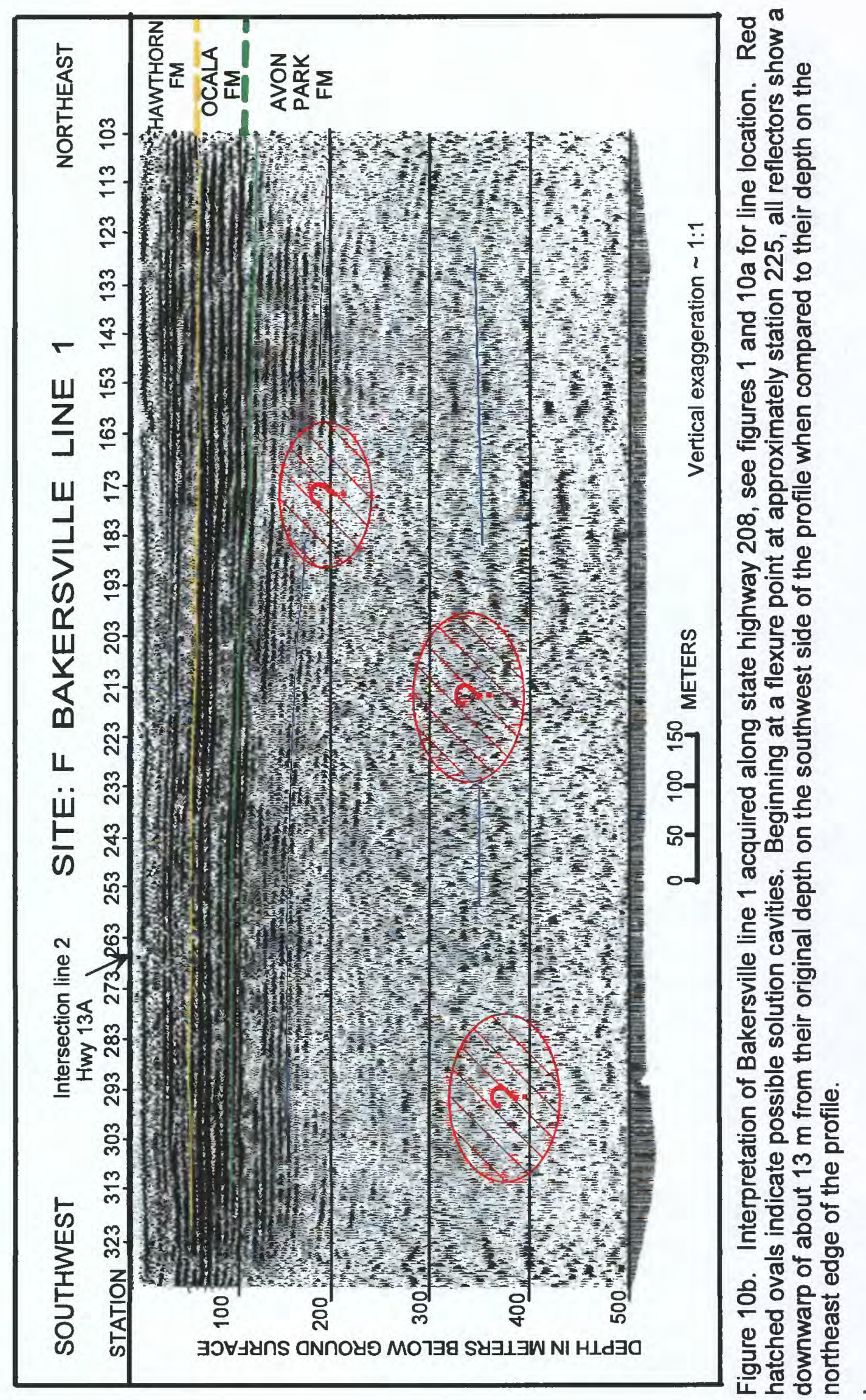




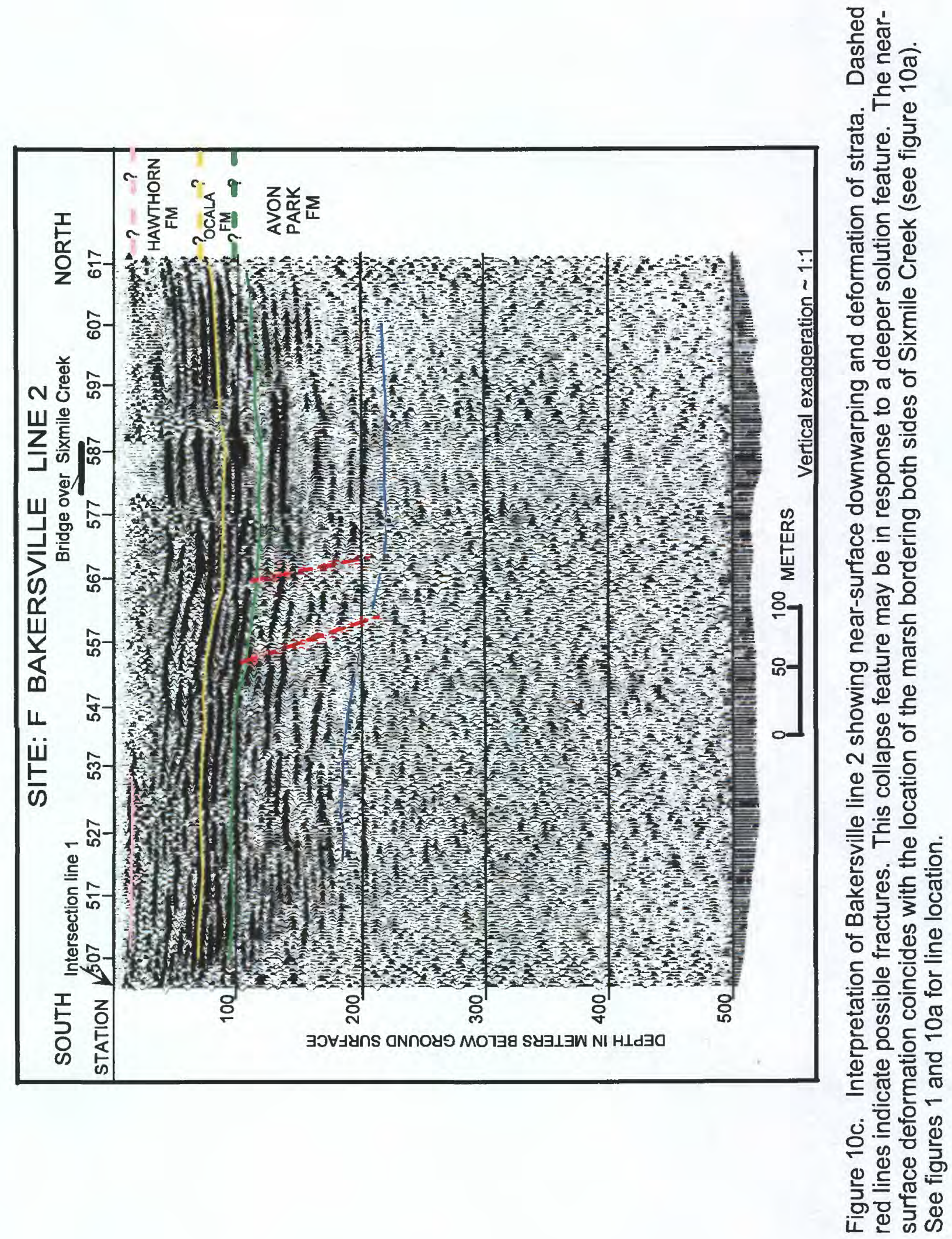


after a $15 \mathrm{~m}$ downward shift. It is possible that this near-surface imaged structure is downwarping over a deeper solution pipe or cavity. It should be noted that on Line 1 a $13 \mathrm{~m}$ down-to-the-northeast flexure of all reflectors, beginning at station 225 and continuing beyond the northeastern edge of the profile, was identified. The amount of downwarping on Line 1 is approximately the same as that on Line 2 . There is the possibility that the downwarping observed on both lines is related to each other. Of further interest is the fact that this downwarp appears to coincide with the surface location of the swampy channel of Six Mile Creek (see figure 10a), perhaps suggesting that the creek may be following a 'solution valley' (i.e. Evans, 1994).

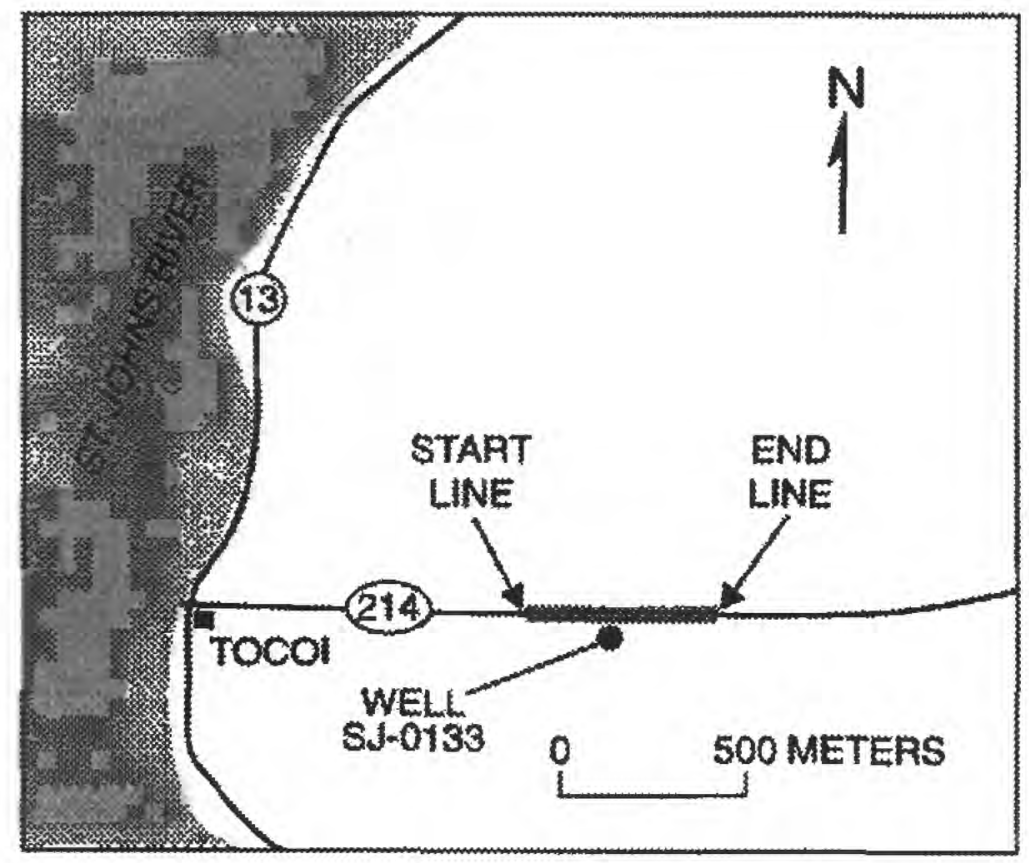

Figure 11a. Location of the highresolution seism ic line near Tocio, Florida (Site G, figure 1).

\section{Site G: Tocoi Line 1}

One high-resolution seismic reflection profile (figure 11b) was acquired near Tocoi along Florida State Highway 214 (figures 1 and 11a). The data quality at Tocoi is lower than average for this project. No well logs were available for stratigraphic correlation from the investigated well, SJ-0133) which is located approximately $10 \mathrm{~m}$ south of Station 160 . This profile was acquired using the Wacker sources with a receiver spacing of 5 meters (Table 1a). Data quality is good for reflectors to a depth of $150 \mathrm{~m}$. However, deeper reflections are generally low in amplitude, possibly due to the nearby operation of heavy farm machinery.

An observation of the yellow highlight reflector (see figure 11b) shows downwarped reflectors between stations 150 and the west end of the profile. The maximum downwarp is about $10 \mathrm{~m}$ beneath station 127 . From this point, the reflector shallows to the west. Where it crosses the west edge of the profile, depth is $15 \mathrm{~m}$ shallower than on the east edge of the profile. This deformation is visible in reflectors from approximately $20 \mathrm{~m}$ to $160 \mathrm{~m}$. Small segments of reflectors (blue highlight) between 200 and 220 depth, beneath stations 110 to 115 , also appear to show an eastward dip similar to what is seen in the shallower reflectors. Two reflectors between 340 and $390 \mathrm{~m}$ depth, traceable from the east side of the profile, appear to be offset and downwarp to the west beginning about station 147. These deeper reflectors west of station 135 are absent. The absence of deeper reflectors west of station 135 may be the result of poor data quality acquisition or it may represent a washout zone caused by a solution feature as seen in other profiles. This later interpretation could be supported by the opposing dip directions of reflectors below $200 \mathrm{~m}$. 




Figure 11b. Interpretation of Tocoi line 1 seismic profile, see figures 1 and $11 \mathrm{a}$ for location. Deformation of yellow highlighted reflector beneath station 150 and truncation and/or offset of deeper reflectors (blue) may be an indicators of fracture zones (dashed red lines). 
Several fracture zones (red line, dashed where tentative) are interpreted in the data. The zone beneath station 147 appears to displace reflectors in the upper $100 \mathrm{~m}$ between stations 140 to 150 and approximately coincides with the eastern edge of the downwarped area. Two other sub-parallel faults are interpreted to the west of the aforementioned fracture. It is unclear but all fracture zone may extend to depth and may offset reflectors between 340 and $390 \mathrm{~m}$.

\section{DISCUSSION AND CONCLUSIONS}

Examples of several different types of karst features have been successfully imaged, some of which appear to influence and/or control the local hydrogeology. These include: solution pipes, buried sinkholes, cavities, and fracture zones.

At Site A: Fort George Island, two perpendicular seismic reflection profiles image a solution pipe whose near-surface ( 40 to $140 \mathrm{~m}$ depth) area of deformation is estimated to measure about $200 \mathrm{~m}$ by at least $475 \mathrm{~m}$ (figure 5a). The imaged depth of this feature is deep into the Avon Park Formation and possibly into the Oldsmar Formation. These two profiles (figures 5b-c) present clear evidence that a karst solution feature has breached the middle semi-confining unit within the Floridan aquifer and possibly the semi-confining unit that separates the upper zone of the Lower Floridan aquifer from the Fernandina zone. The significance and relationship of this interpreted solution feature to the Fort George Island hydrogeology and water quality is illustrated on figure 5a. The figure shows the correlation that exists between the interpreted limits of the solution pipe and the highest levels of chloride concentrations measured in the Fort George Island wells. Not only does this feature lie within close proximity to the wells that have the high chloride concentration, but its imaged vertical extent lends credence to the theory that warmer and more saline water from the Lower Floridan aquifer is migrating upward through breaches and mixing with fresh water in the Upper Floridan aquifer system (see figures 2, 3 and 5a).

At Site: B, the Oakridge well field, two or three possible solution pipes are interpreted. The interpreted solution pipe feature identified on Line 1 (figure 6b) is in close proximity to well D-665 which was removed from service because of high chloride concentration $(690 \mathrm{mg} / \mathrm{L}$ in 1994) (Phelps and Spechler, 1996). Drill-hole logs for well D-665 noted that a cavity filled with soft, sandy limestone was encountered at a depth of $360 \mathrm{~m}$ (Phelps and Spechler, 1996). Additionally, Oakridge Lines 5 and 6 (figures $6 \mathrm{f}$ and g) also image solution pipe features.

Other types of solution features were also imaged by the high-resolution seismic reflection data. The Jacksonville Beach profiles imaged what is interpreted to be near vertical, closely spaced, narrow fracture zones and cavities. The two Bakersville lines revealed an area of deformed and downwarped surface strata that may be influencing the location of Six Mile Creek.

Overall, the land-based, high-resolution seismic reflection techniques employed were successful at imaging the significant formational contacts and inter-formational stratigraphic units that define the boundaries of the surficial and Floridan aquifer systems. In addition, these data showed that these methods were also successful in imaging evidence for both large and small scale karst features (i.e. solution pipes, collapse sinkholes, isolated cavities and narrow fracture zones). The limiting factor for the application of these techniques is the vertical and spatial resolution of the data relative to the size of the dissolution features we are attempting to image. Succinctly put, high-resolution seismic data acquisition is a viable technique for studies of this nature if the features are large enough to be imaged. We conclude that the high-resolution seismic reflection technique can be used as a tool to evaluate potential well field sites in future water supply planning. 
In future work small changes in acquisition parameters would help in the better imaging of strata such as the semi-confining unit within the middle to lower Avon Park Formation. It would also be useful to more clearly establish the seismic signature of the contact between the Avon Park and Oldsmar Formations which is related to a lower semi-coning unit. Additionally, one or two long surveys (2-3 $\mathrm{km}$ in length) would be useful in determining the stratigraphic variations of the formations being imaged. These longer lines would all furnish information on the variability of size, the different types, and the density of karst features.

\section{ACKNOWLEDGMENTS}

The authors gratefully acknowledge the many individuals from the St. Johns River Water Management District who participated in the data acquisition phase of this project. Without their hard work this report would not have been possible. We also with to thank Shawn Dadisman, Ann Tihansky, and Eleanor Omdahl for their scientific and editorial reviews. 


\section{REFERENCES}

Barbier, M.G., 1983, The Mini-Sosie method: Boston, Massachusetts, International Human Resources Development Corp., 86 p.

Beck, B.F. and Sayed, S., 1991, The sinkhole hazard in Pinellas County a geologic summary for planning purposes: Florida Sinkhole Research Institute Report, no. 90-91-1, 140 p.

Berkout, A.J., 1984, Seismic resolution: Resolving power of acoustical echo techniques, in Helbig K. and Trietel S. (eds.), Handbook of Geophysical Exploration, Section I, Seismic Exploration, Geophysical Press, London, p. 181-192.

Evans, M.W., Synder, S.W., and Hines, A.C., 1994, High-resolution seismic expression of karst evolution within the upper Floridian aquifer system: Crooked Lake, Polk County, Florida: Journal of Sedimentary Research, vol. B-64, no. 2, p. 232-244.

Kindinger, J.L., Davis, J.B., and Flocks, J.G.,1994, High-resolution single-channel seismic reflection surveys of orange lake and other selected sites of north central Florida: U.S. Geological Survey Open-File Report 94-616, 48 p.

Locker, S.D., Brooks, G.R., Doyle, L.J., 1988, Results of a seismic-reflection investigation and hydrogeologic implications for Lake Apopka, Florida: Center for Near-shore Marine Science, Final Report to the St. John's River Water Management District, 39 p.

Meisburger, E.P, and Duane, D.B., 1976, Neogene sediments of the Atlantic Inner Continental shelf off northern Florida: American Association of Petroleum Geologists Bulletin, vol. 60 , no. 11, p. 2019-2037.

Miller, J.A., 1986, Hydrogeologic framework of the Floridan aquifer system in Florida and in parts of Georgia, Alabama, and South Carolina: U.S. Geological Survey Professional Paper 1403-B, 91 p., 28 pl.

Missimer, T.M. and Gardner, R.A., 1976, High-resolution seismic profiling for mapping shallow aquifers in Lee County, Florida: U.S. Geological Water-Resources Investigation no. 76$45,30 \mathrm{p}$.

Odum, J. K., Luzietti, E.A., Stephenson, W. J., Shedlock, K. M., and Michael, J. A., 1995 Highresolution seismic reflection surveys of the northwest rift boundary near Marston, Missouri, in Shedlock, K .M., and Johnston, A. C., eds., Investigations of the New Madrid seismic zone: U.S. Geological Survey Professional Paper 1538, P1-P18.

Phelps, G.G., and Spechler, R.M., 1997, The relation between hydrogeology and water quality of the lower Floridan aquifer in Duval County, Florida, and implications for moitoring movement of saline water: U.S. Geological Survey Water Resources Investigations Report 96-4242, 58 p. 
Popenoe, P., Kohout, F.A., and Manheim, F.T., 1984, Seismic-reflection studies of sinkholes and limestone dissolution features on the northeast Florida shelf: in B.F. Beck (ed.), Sinkhole: their geology, engineering, and environmental impact, Proceedings of the first multidisciplinary conference on sinkholes, Orlando, Florida, Oct. 15-17, p.43-57.

Pratt, T.L., Dolan, J.F., Odum, J.K., Stephenson, W.J., Williams, R.A., and Templeton, M.E., Multi-scale seismic imaging of active fault zones for hazards assessment: A case study of the Santa Monica fault zone, Los Angles: Geophysics (in press).

Sheridan, R.E., Crosby, J.T., Bryan, G.M., and Stoffa, P.L., 1981, Stratigraphy and structure of southern Blake Plateau, northern Florida straits and northern Bahama platform from multi-channel seismic reflection data: American Association of Petroleum Geologists Bulletin, vol. 65, p. 2571-2593.

Sheriff, R.E., 1984, Encyclopedic Dictionary of Exploration Geophysics: Society of Exploration Geophysicists, Tulsa, Okla., p.120.

Snyder, S.W., Evans, M.W., Hine, A.C., and Compton, J.S., 1989, Seismic expression of solution collapse features from the Florida platform: in Beck, B.F and Wilson, W.L. (eds), Proceedings of the third multidisciplinary conference on sinkholes, St. Petersburg, Florida, Oct. 2-4, 1989, A. A. Balkema Press, NY, p. 281-298.

Spechler, R.M., 1994, Saltwater intrusion and quality of water in the Floridian aquifer system, northeastern Florida: U.S. Geological Survey Water-Resources Investigations Report 92$4174,76 \mathrm{p}$.

Spechler, R.M., 1996, Detection and quality of previously undetermined Floridan aquifer system discharge to the St. Johns River, Jacksonville, to Green Cove Springs, Northeastern Florida: U.S. Geological Survey Water-Resources Investigation Report 95-4257, 29 p.

Steeples, D.W., and Miller, R.D., 1987, Direct detection of shallow subsurface voids using highresolution seismic-reflection techniques: in Beck, B.F and Wilson, W.L. (eds), Karst Hydrgeology: Engineering and Environmental Applications, Proceeding of the second multidisciplinary conference on sinkholes and the environmental impact of karst, Orlando, Florida, Feb. 9-11, 1984, A. A. Balkema Press, p. 217-224.

Stephenson, W.J., Odum, J.K., Shedlock, K.M., Pratt, T.L., and Williams, R.A., 1992, MiniSosie high-resolution seismic reflection method aids hazard studies: Eos, American Geophysical Union Transactions, vol.. 73, no. 44, p. 473-476.

Stephenson, W.J., Rockwell, T. Odum, J.K., Shedlock, K.M., and Okaya, D., 1995, Seismic reflection and geomorphic characterization of the onshore Palos Verde fault zone, Los Angles, California: Bulletin of the Seismological Society of America, vol. 85, no. 3, p. 943-950.

Subsurface Detection Investigations Inc., 1992, High-Resolution seismic reflection profiling in selected lakes in the St. John's Water Management District, SDI Final Report to the St. John's River Water Management District: SP:SJ 92-SP-13, 81 p. 
Tihansky, A.B., Arthur, J.D., Dewitt, D.J., 1996, Sublake geologic structure from highresolution seismic-reflection data from four sinkhole lakes in the Lake Wales Ridge, Central Florida: U.S. Geological Survey Open-File Report 96-224, 72 p.

Toth, D.J., 1990, Geohydrologic summary of the Floridian aquifer in coastal areas of Nassau, Duval, and northeast St. Johns Counties: St. Johns River Water Management District Technical Publication SJ 90-5, 91 p.

Waltham, A. C., 1989, Ground Subsidence: London, Blackie, 202 p.

White, W.B., 1988, Geomorphology and Hydrology of Karst Terrains: Oxford, Oxford University Press, $464 \mathrm{P}$.

Widess, M.B., 1973, How thin is thin?: Geophysics, 38, p. 1176-1180. 


\section{APPENDIX:}

Uninterpreted High-Resolution Seismic Reflection Profiles 


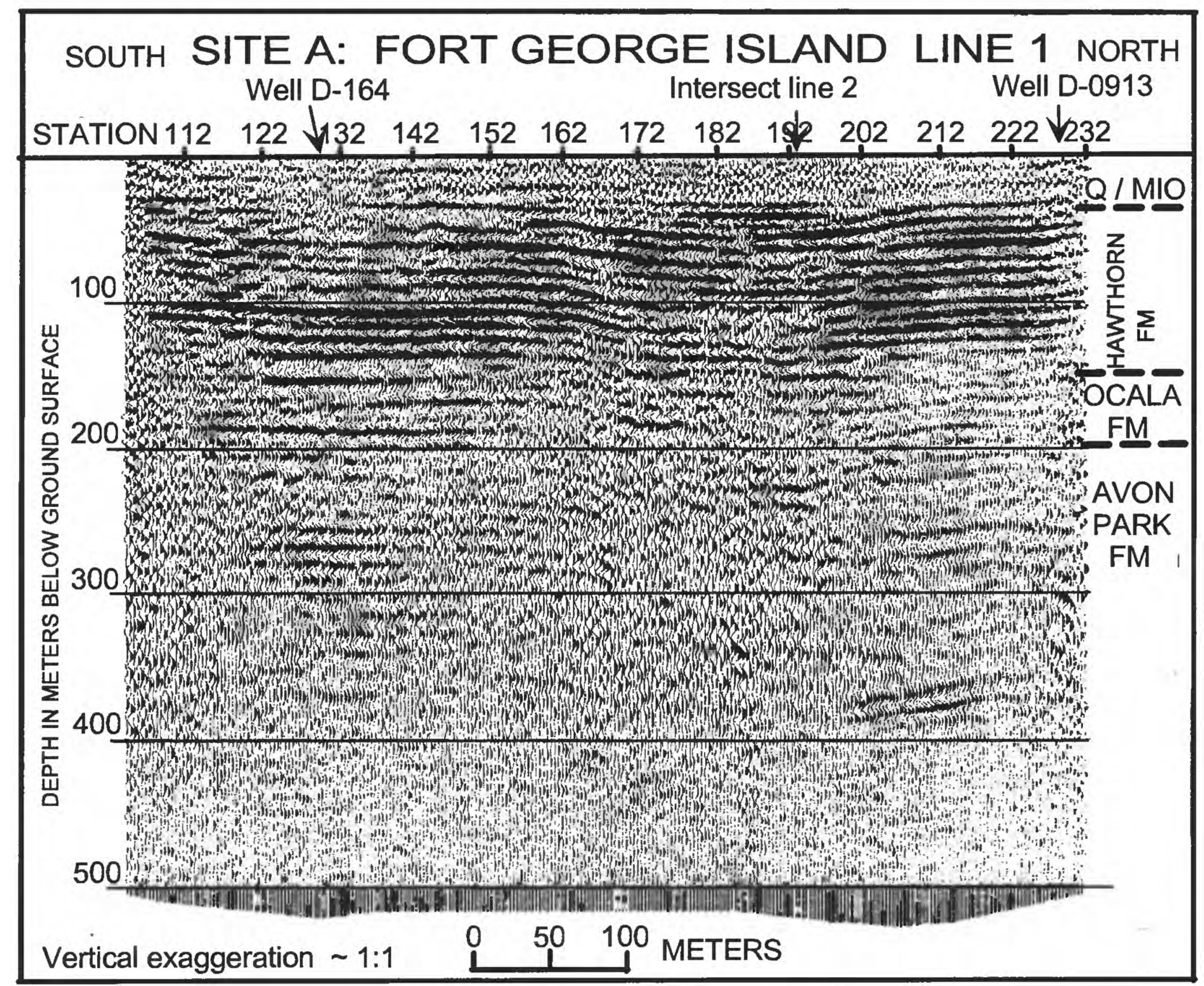

Figure 5b. Site A: Fort George Island line 1 acquired from south to north using three earth tampers as the energy source, see figures 1 and $5 a$ for location. 


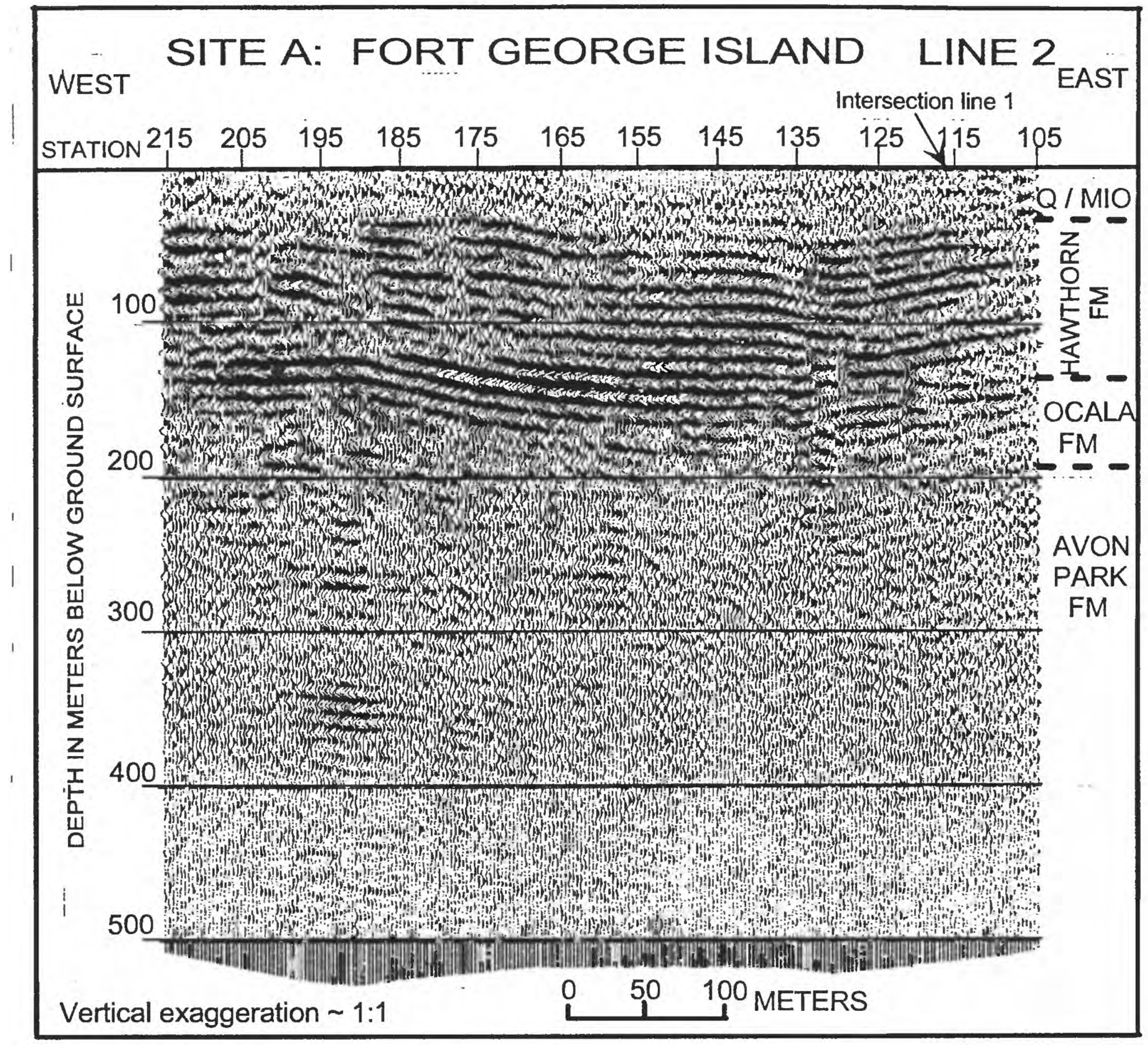

Figure 5c. Site A: Fort George Island line 2 acquired from east to west perpendicular to Fort George Island line 1, see figures 1 and $5 a$ for location. 


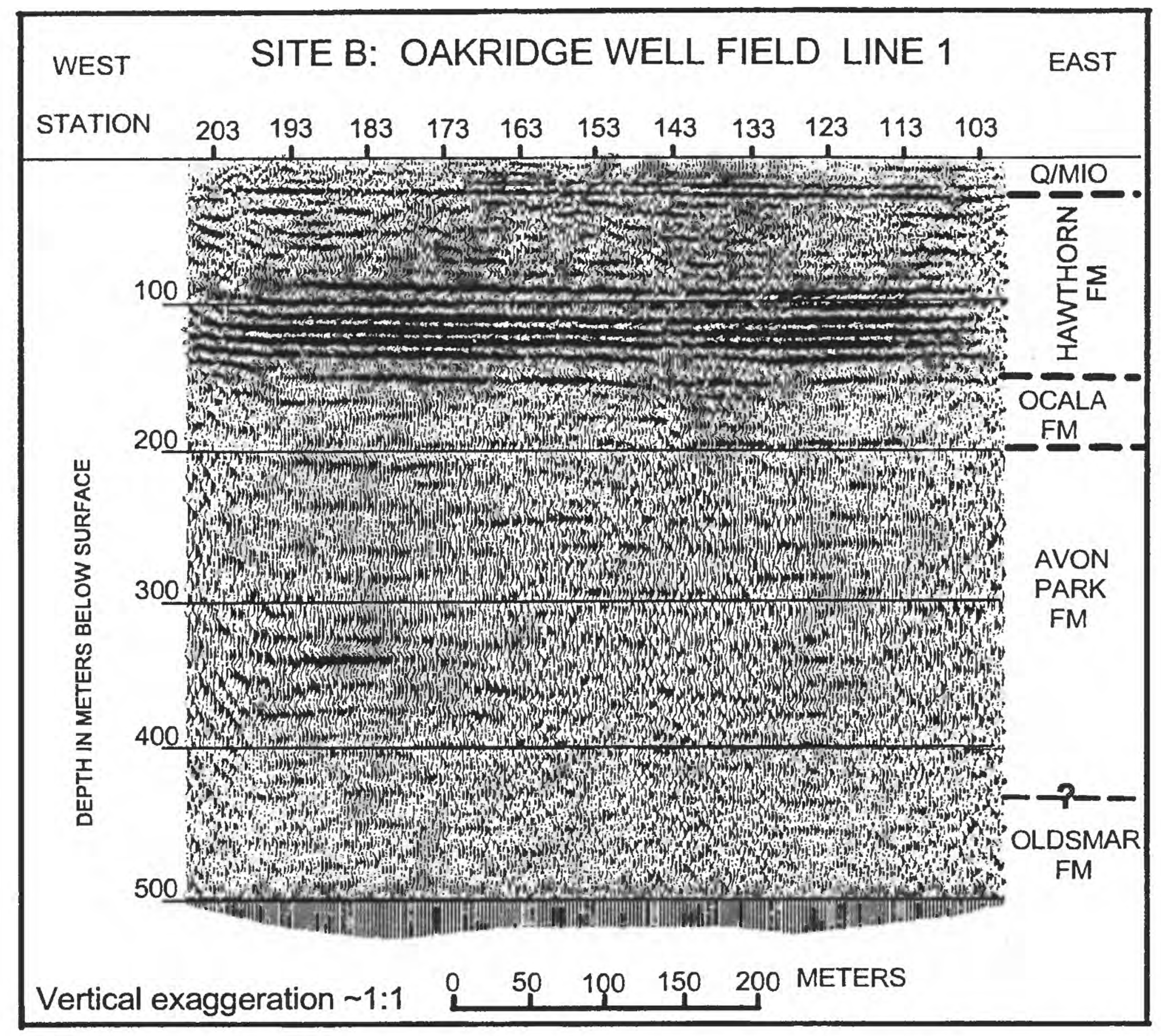

Figure $6 \mathrm{~b}$. Site B: Oakridge well field line 1 acquired from east to west along Alden Street, see figure 1 and $6 a$ for location. 


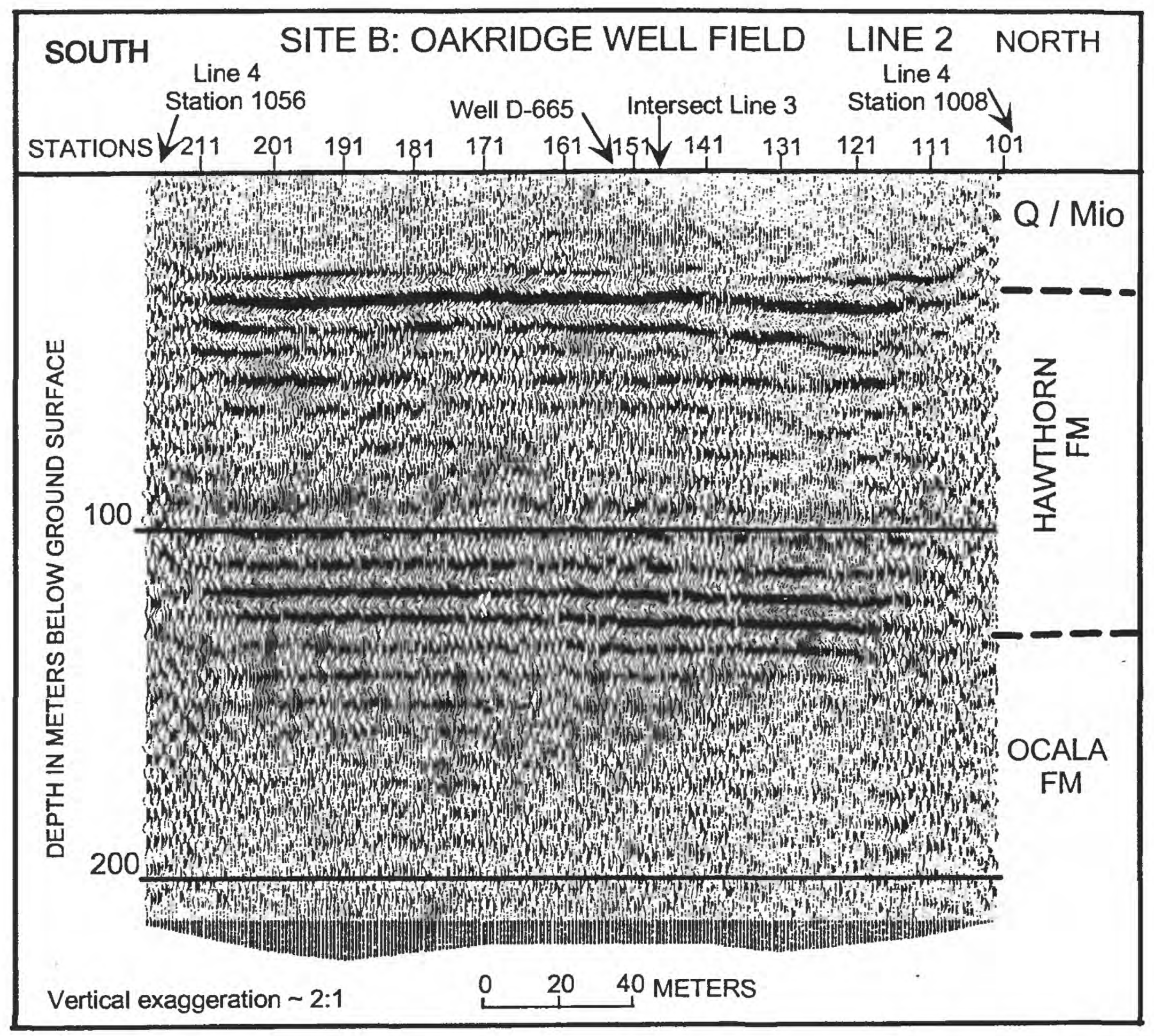

Figure $6 \mathrm{c}$. Site B: Oakridge well field line 2 acquired with a $10 \mathrm{lb}$ sledgehammer energy source and with a $2 \mathrm{~m}$ geophone spacing, see figures 1 and $6 a$ for line location. 


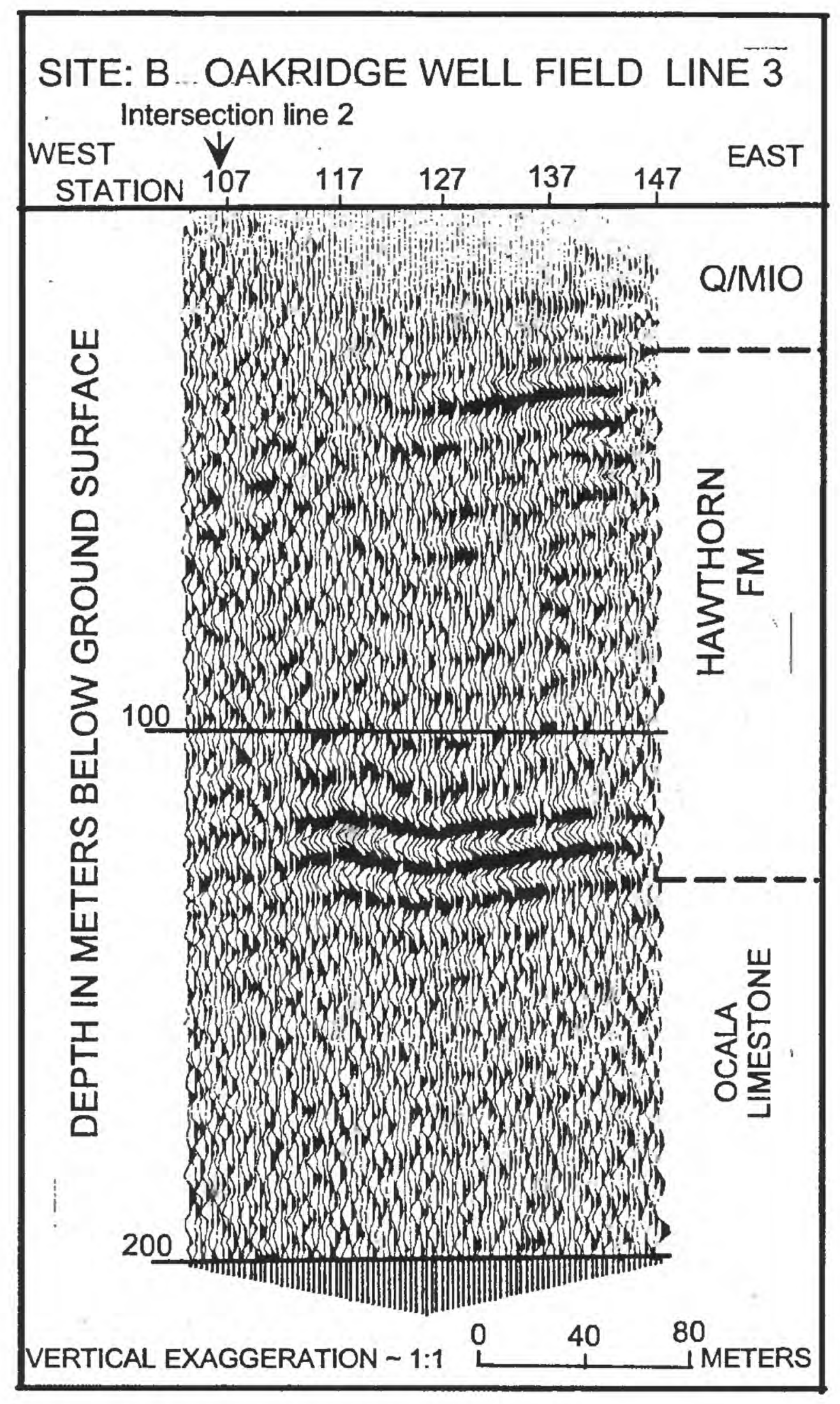

Figure 6d. Site B: Oakridge well field line 3 aquired perpendicular to Oakridge well field lines 2 and 4 , see figures 1 and $6 a$ for line locations. 


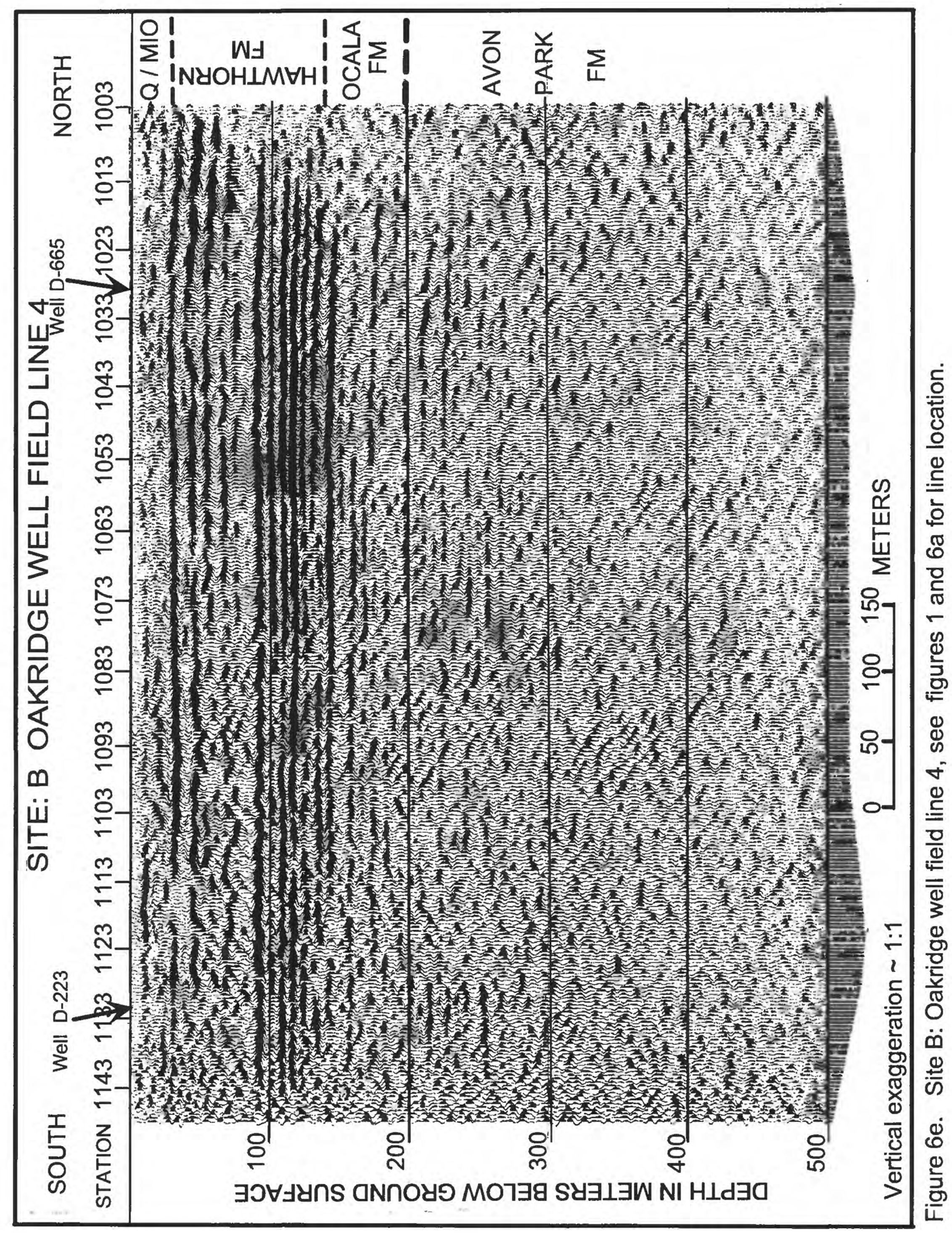




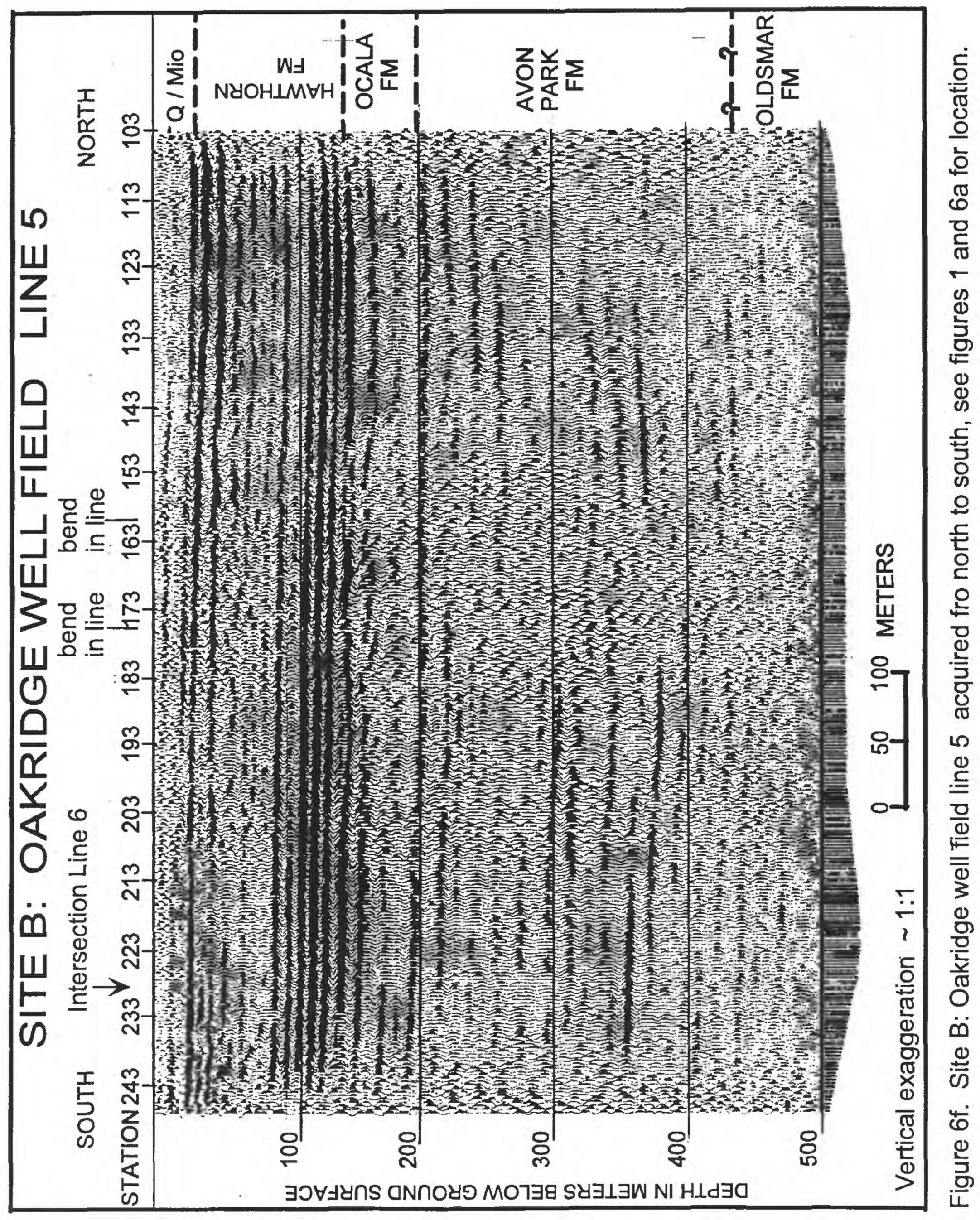




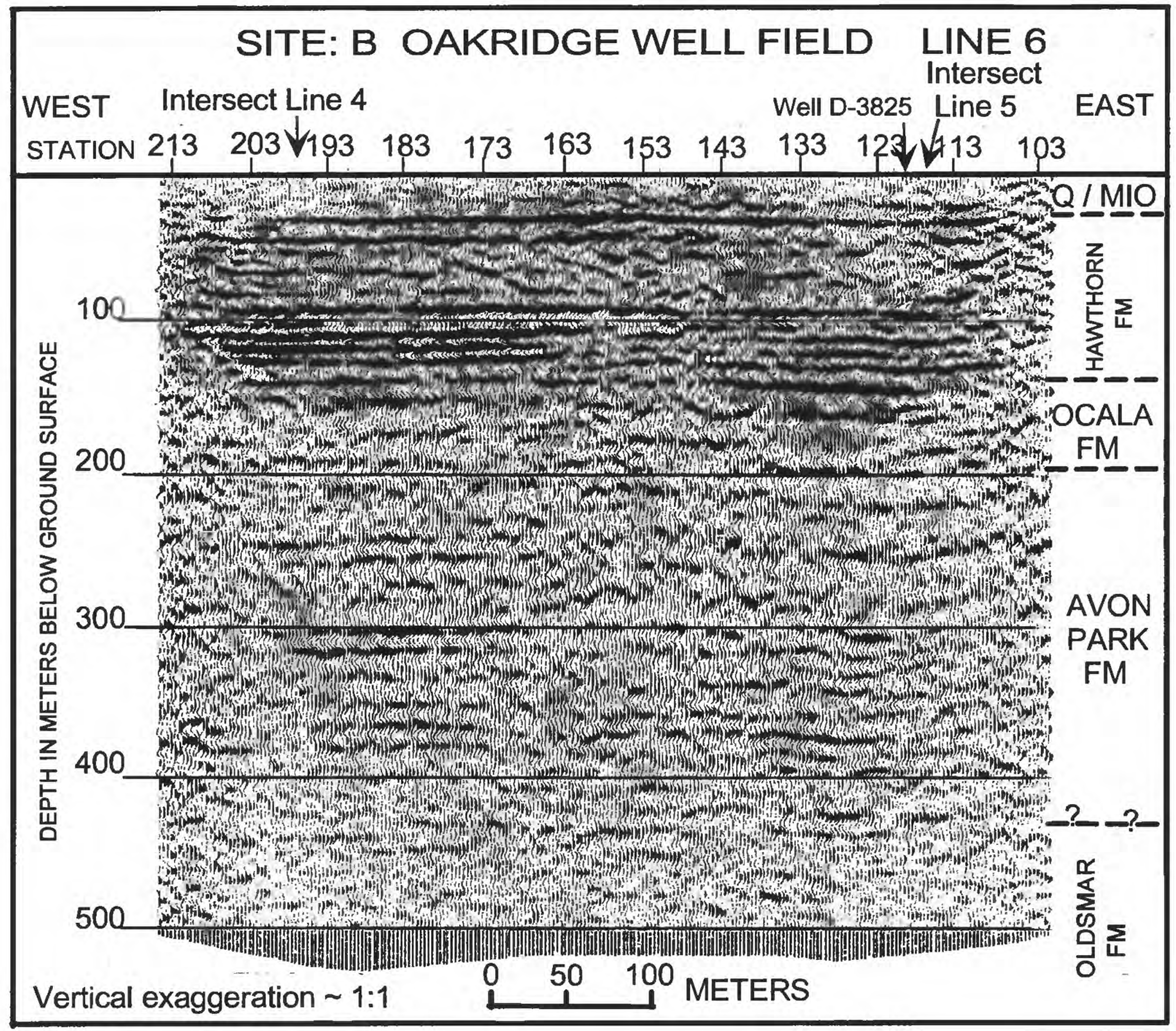

Figure $6 \mathrm{~g}$. Site B: Oakridge well field line 6 acquired from east to west, see figures 1 and $6 a$ for location. 


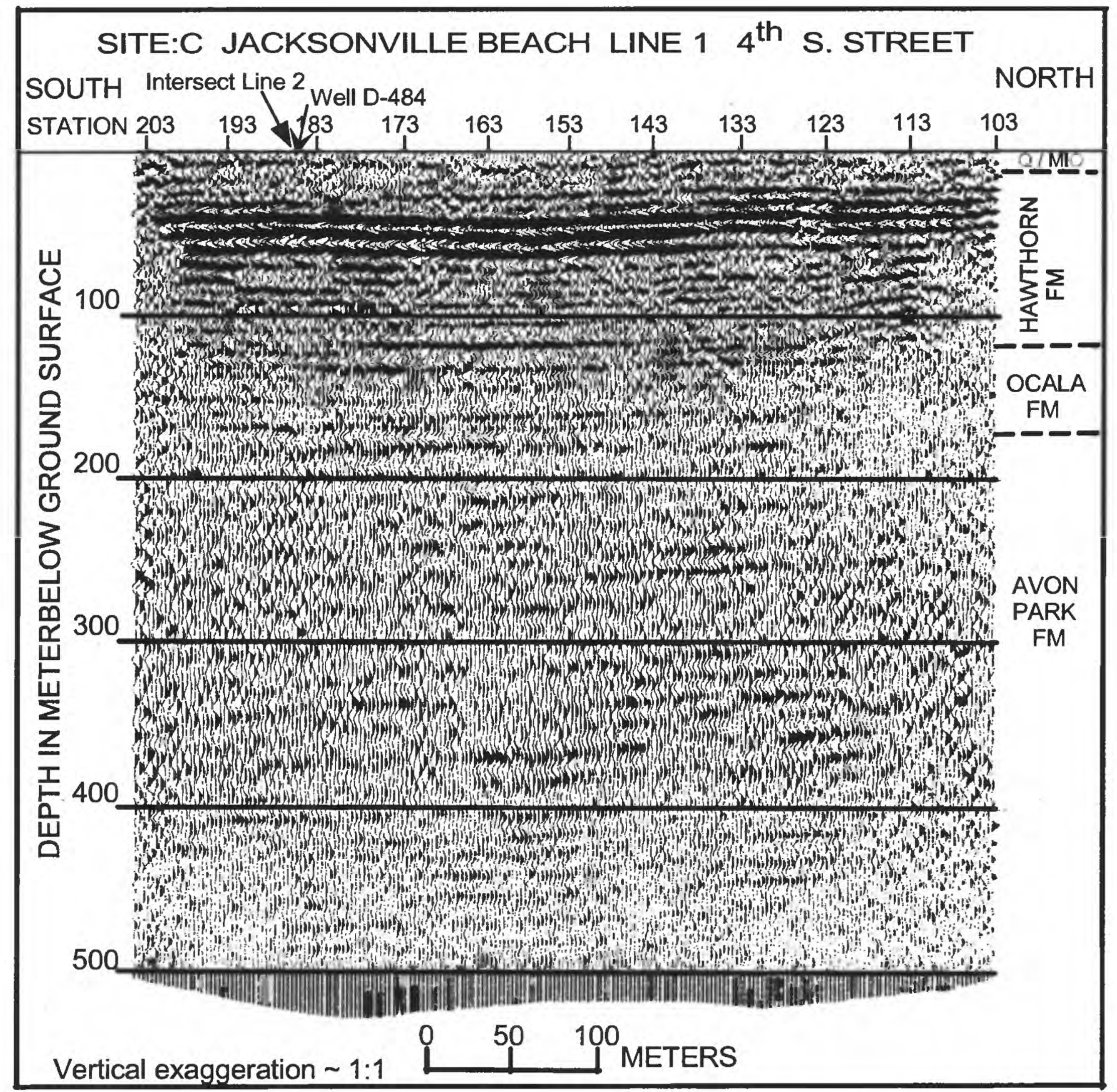

Figure 7b. Site C: Jacksonville Beach line 1, see figures 1 and $7 \mathrm{a}$ for line location. 


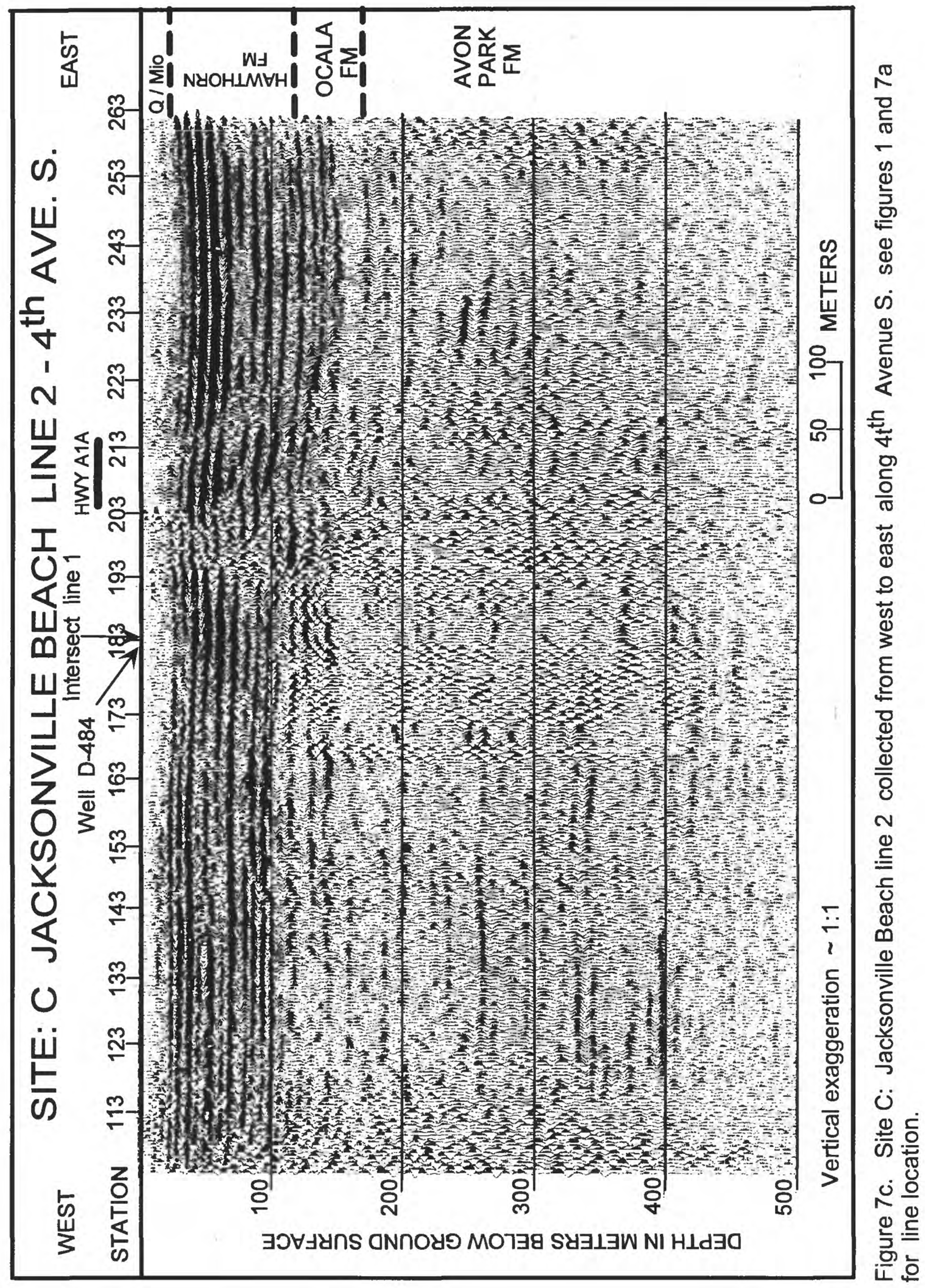




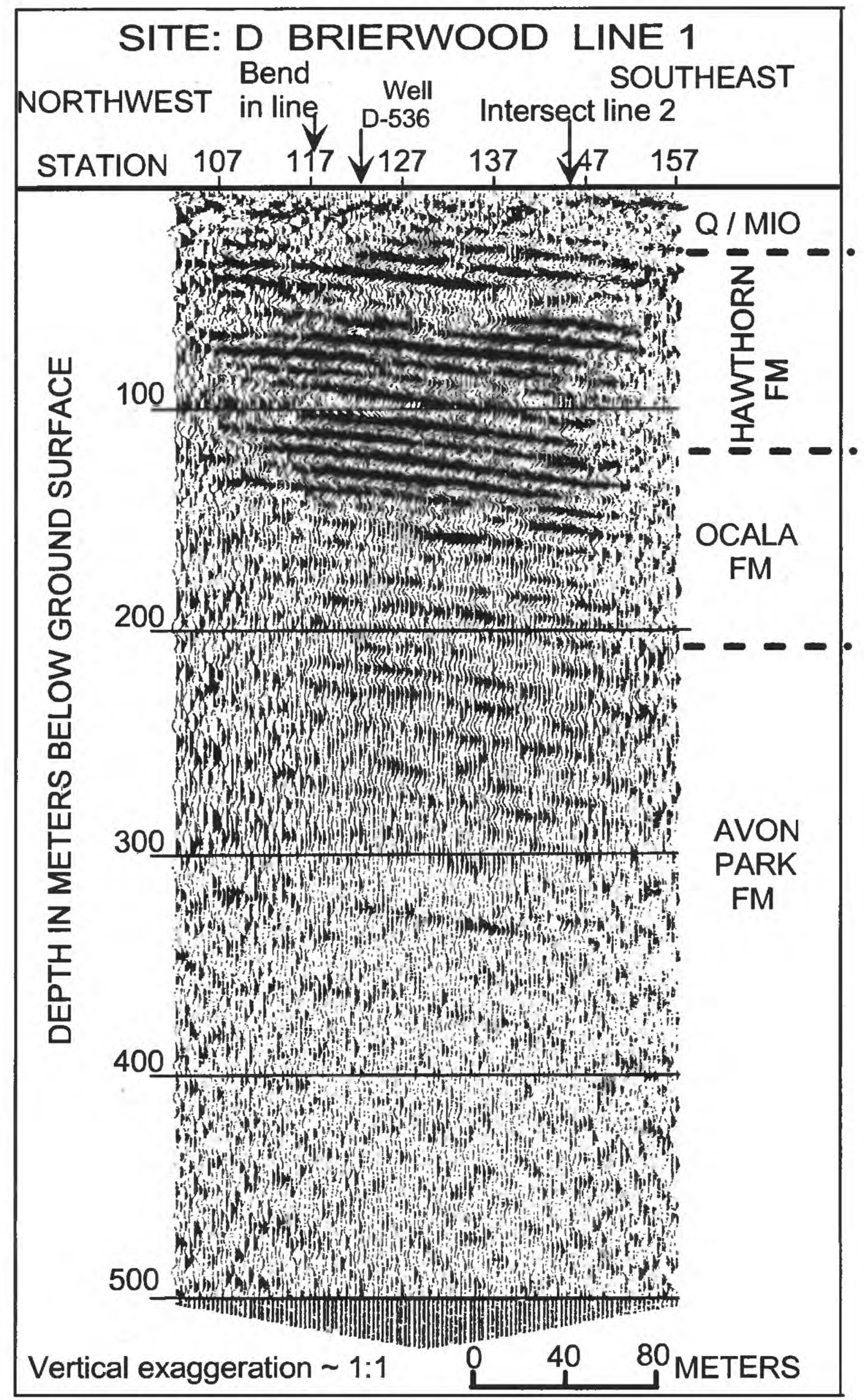

Figure 8b. Site D: Brierwood line 1 acquired near the Brierwood water treatment plant, see figures 1 and $8 a$. 


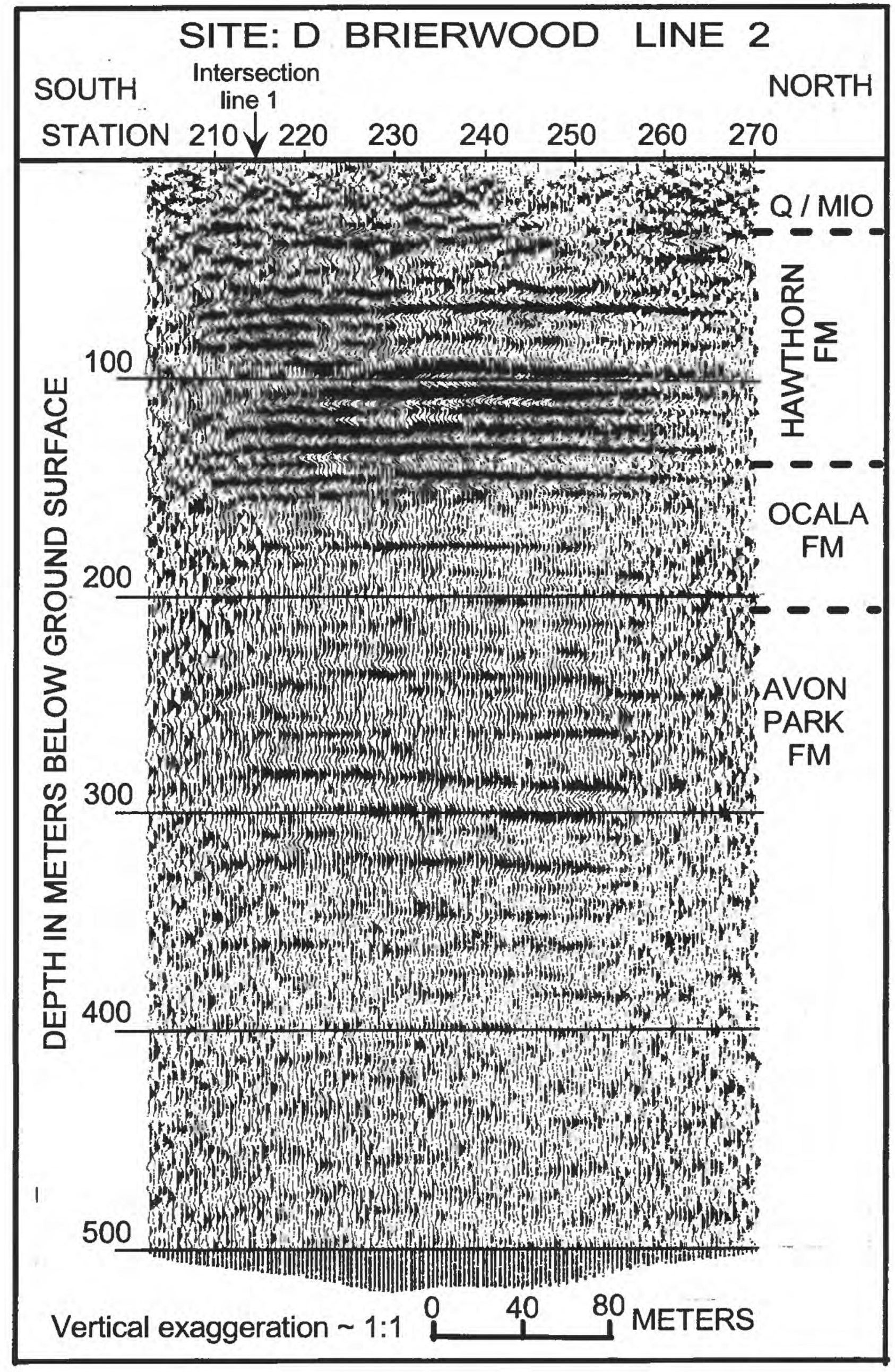

Figure 8c. Site D: Brierwood line 2, see figures 1 and 8 a for line location. This line was acquired at approximately 70 degrees to line 1. 


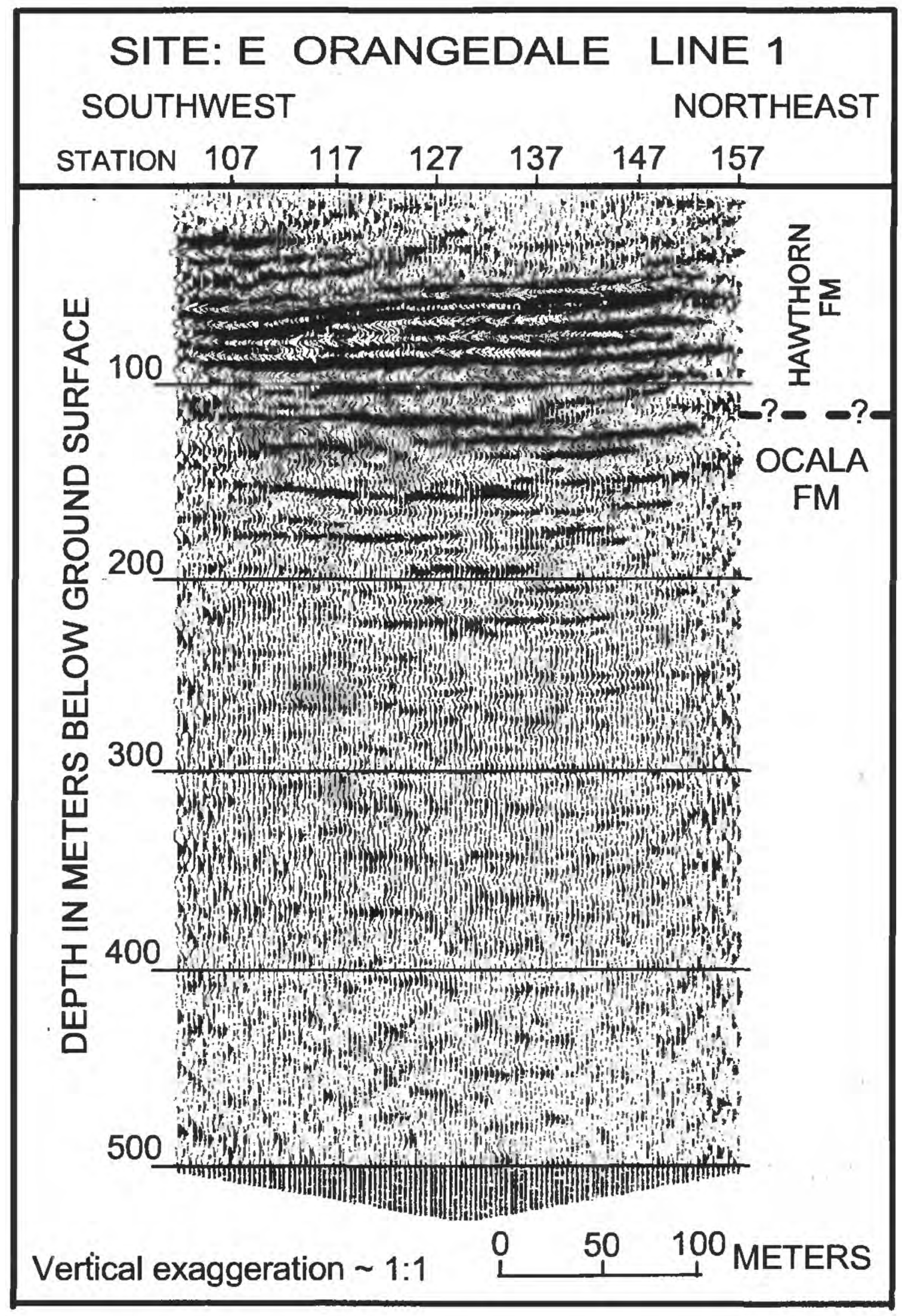

Figure 9b. Site E: Orangedale high-resolution seismic reflection profile of line 1, see figures 1and 9a for line location. 







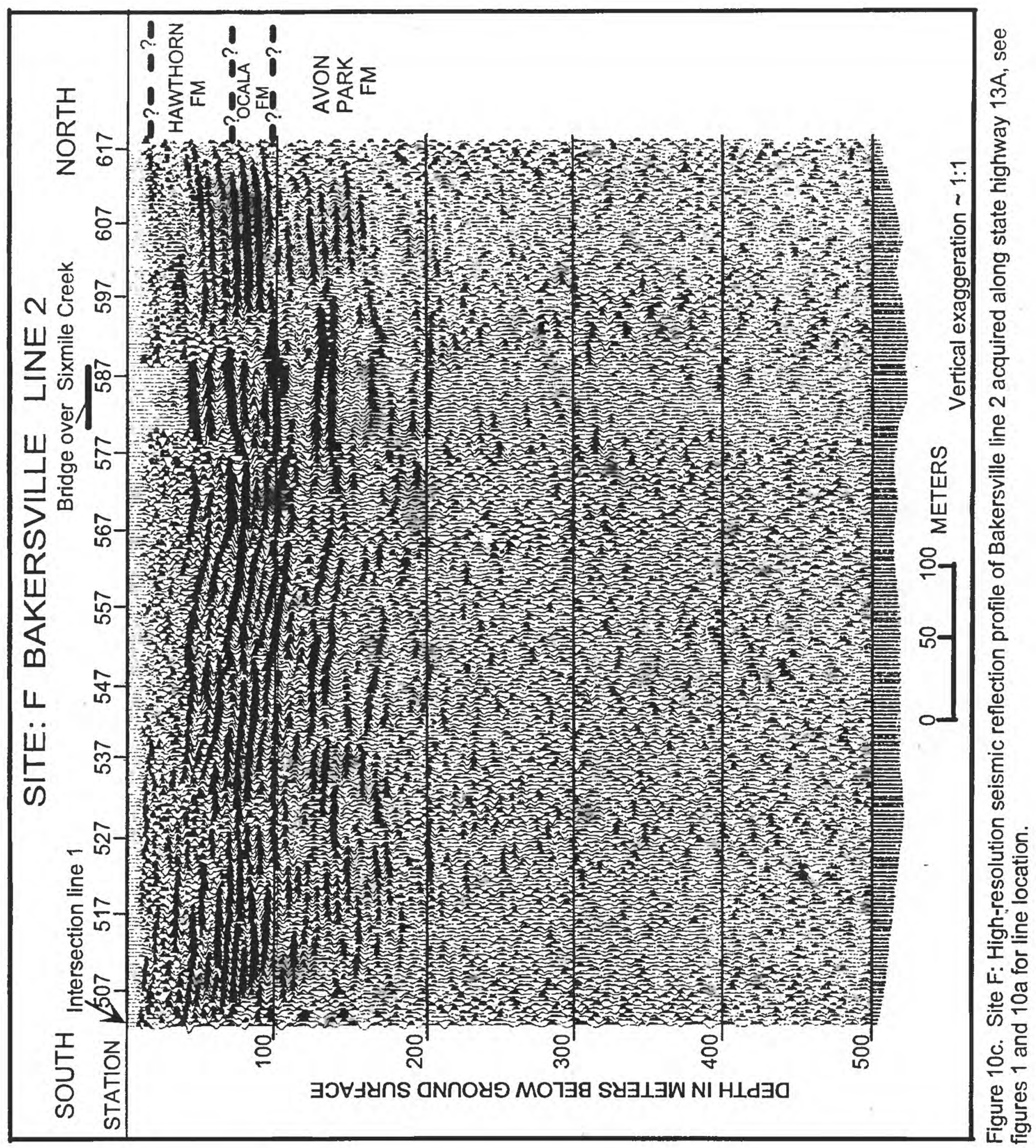




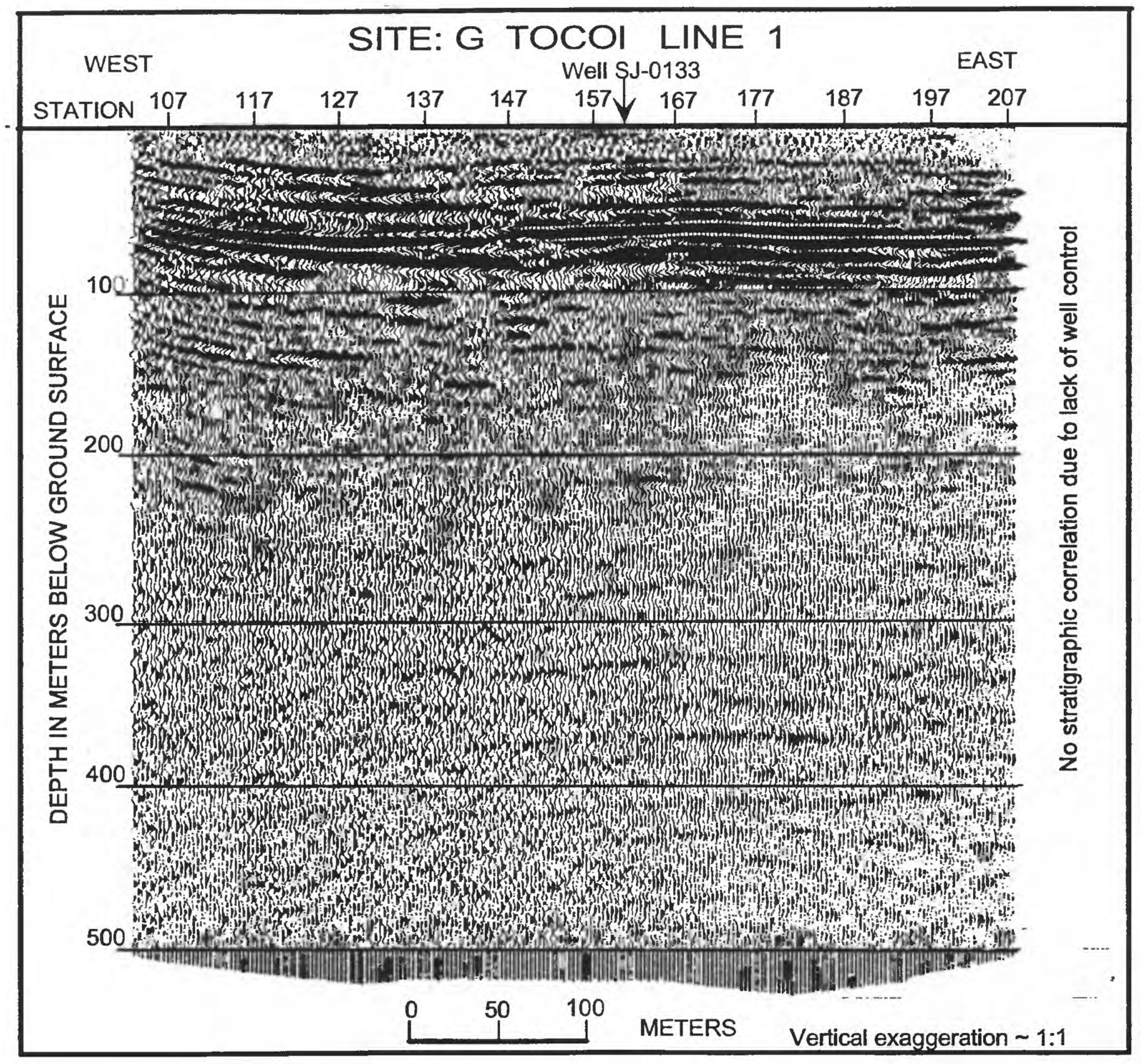

Figure 11b. Site G: High-resolution seismic reflection profile of Tocoi line 1 acquired along state highway 214 , see figures 1 and $11 a$. 